\title{
A global systematic review of publications concerning the invasion biology of four tree species
}

\author{
Anatoliy Khapugin ${ }^{1,2}$ (D)
}

Key words: Acer negundo, Ailanthus altissima, Alien plant species, Biological invasion, Fraxinus pennsylvanica, Robinia pseudoacacia.

Ključne besede: Acer negundo, Ailanthus altissima, tujerodne rastlinske vrste, biološka invazija, Fraxinus pennsylvanica, Robinia pseudoacacia.
Received: 4. 1. 2019

Revision received: 3. 5. 2019

Accepted: 10. 5. 2019

\begin{abstract}
Paper presents a systematic global review of Acer negundo, Fraxinus pennsylvanica, Ailanthus altissima, Robinia pseudoacacia invasions focusing on the Scopus and Web of Science databases. We examined the data on papers, study areas, habitat studied, topic discussed. We hypothesized that these species were studied evenly throughout their invaded ranges and, as such, indexed by international databases. We asked whether four selected species are presented evenly in publications related to their invaded ranges, and whether both selected databases cover well a content of these papers. We found 48 papers for $A$. negundo, 14 - for $F$. pennsylvanica, 83 - for $A$. altissima, 96 - for $R$. pseudoacacia. A high percentage of the studies were conducted in Central Europe and USA (for A. altissima), while Eastern Europe, Russia, Western United States were poorly represented. Most studies were conducted in forests, and focused on impacts or distribution of aliens in invaded range, and their control and management. We encountered habitat types invaded by trees, factors influencing tree invasions, consequences of invaders' impact on ecosystems, counteracting measures. We concluded that the use only Web of Science and Scopus is not sufficient to obtain the complete data about the invasion biology.

Izvleček

Predstavljamo sistematičen globalen pregled literature o invaziji vrst Acer negundo, Fraxinus pennsylvanica, Ailanthus altissima in Robinia pseudoacacia na podlagi baz podatkov Scopus in Web of Science. Pregledali smo podatke v člankih, preučevanih območjih, habitatih in temah raziskav. Postavili smo hipotezo, da so bile vrste preučevane enakomerno v celotnem arealu naselitve in da so objave indeksirane v mednarodnih bazah podatkov. Predvidevali smo, da so izbrane štiri invazivne vrste zmerne cone v člankih zastopane enakomerno v njihovem arealu nove poselitve in da so primerno zbrani v obeh bazah. Kot rezultat smo našli 48 člankov o $A$. negundo, 14 člankov o $F$. pennsylvanica, 83 člankov o A. altissima in 96 člankov za $R$. pseudoacacia. Velik delež raziskav je bil opravljen v zahodni Evropi in ZDA (za $A$. altissima), medtem ko so bile raziskave iz vzhodne Evrope, Rusije in zahodnih ZDA slabo zastopane. Večina raziskav je bila narejenih v gozdovih in so se osredotočile na učinke ali razširjenost tujerodnih vrst, pa tudi na njihovo omejevanje in gospodarjenje z njimi. Posebej izpostavljamo najpomembnejše informacije o habitatnih tipih, ki jih tujerodne vrste naseljujejo, dejavnikih, ki vplivajo na njihovo naselitev, posledicah na naravne ekosisteme in merah omejevanja invazij. Zaključimo lahko, da samo uporaba baz Web of Science in Scopus ni dovolj za posplošene zaključke o biologiji invazije, še posebej, če ocenjujemo območja izven Severne Amerike in Zahodne Evrope.
\end{abstract}

\footnotetext{
1 Tyumen State University, 625003, Volodarskogo Street, 6, Tyumen, Tyumen region, Russian Federation.

2 Joint Directorate of the Mordovia State Nature Reserve and National Park "Smolny”, 430011, Dachnyi Lane, 4, Saransk, Republic of Mordovia, Russian Federation. E-mail: hapugin88@yandex.ru
} 


\section{Introduction}

Biological invasions are a threat to biodiversity conservation on all levels (populations, species, communities, ecosystems) (Dumalisile \& Somers 2017, Fateryga \& Bagrikova 2017). Invasive species impact affects ecosystem services and decrease native species abundance through numerous mechanisms such as predation, hybridization, competition and indirect effects (Simberloff et al. 2013). They are considered as one of the major drivers of global biodiversity change (Bellard et al. 2013, Pyšek et al. 2015, Seebens et al. 2015, Dawson et al. 2017). There are more than 13,000 naturalized vascular plant species globally (van Kleunen et al. 2015). In Europe, more than 12,000 species of alien plants and animals are known (Vilà et al. 2010). In other Eurasian areas including the territory of the Russian Federation, 354 plant species were considered as invasive, including 277 invasive plants in European Russia (Vinogradova et al. 2018).

Among functional groups of invasive plant species, woody plants are distinguished by their long life cycle (Richardson 1998, Richardson \& Rejmánek 2011). Invasions by woody plants often alter the functioning of invaded ecosystems (Richardson et al. 2000, BottollierCurtet et al. 2011, Lazzaro et al. 2018). Moreover, these plants present one of the frequently used test groups in studies of biological invasions (Reichard \& Hamilton 1997, Richardson 1998, Pyšek et al. 2014, Nuñez et al. 2017, Shackleton et al. 2017, Zimmermann et al. 2017, Dyderski \& Jagodziński 2018). Here we focus on field ecological studies of woody plant invasions globally, including natural and semi-natural systems, excluding nonfield studies, i.e. the roles of these invaders, for example in herbal medicine, in fallow agriculture or as objects of greenhouse or laboratory studies.

This review aimed to document data presented in the internationally published literature concerning the invasion biology of four invasive plant species, Fraxinus pennsylvanica Marshall, Acer negundo L., Robinia pseudoacacia L., and Ailanthus altissima (Mill.) Swingle, recognized as the most invasive tree species in the temperate zone of Eurasia. For example, in Russia, covering a large area of Eurasia, Vinogradova et al. (2018) recognized A. negundo and $F$. pennsylvanica as the first and thirty-fourth species respectively in a list of the most invasive plants of Russia, while Lambdon et al. (2008) indicated $R$. pseudoacacia (ranked $9^{\text {th }}$ ), A. altissima (ranked $14^{\text {th }}$ ), and $A$. negundo (ranked $23^{\text {rd }}$ ) among 150 of the most widespread alien plant species in Europe. In addition, $A$. negundo, $R$. pseudoacacia and $A$. altissima were one of the most invasive trees influencing the environment in Turkey (Yazlık et al. 2018), while the first two species were included in the list of the most common alien plant species in European woodlands (Wagner et al. 2017). Robinia pseudoacacia has been included in a list of 26 plant invaders with the greatest impacts in Europe (Rumlerová et al. 2016), as one of "100 of the worst" global list of alien species (Nentwig et al. 2018), the list of the 200 most widely distributed naturalized plant taxa (Pyšek et al. 2017), and in the list of invasive alien species of China (Xu et al. 2012). All four invaders were assessed for the need to prevent or reverse their profound impacts on biodiversity (Carboneras et al. 2018). Among them, major impacts on biodiversity were indicated for $A$. altissima and $R$. pseudoacacia, while $A$. negundo and $F$. pennsylvanica had minor impacts.

One compelling reason for obtaining a better understanding of invasive species in temperate Eurasia is their potential impact on native species and natural ecosystems susceptible to invasion of alien organisms, and to identify knowledge gaps in invasive species and their habitats in different worldwide regions. Knowledge gaps occur in different temperate areas because of the limited availability or accessibility of published data from these areas to researchers in other parts of the world, or because there are fewer resources for invasive biology research in these regions. Limitations on the accessibility of the data for researchers in North America, Europe and other developed countries may also be due to huge number of non-English-language publications or publications in regional journals which are not indexed in major international databases. This issue potentially introduces a bias in understanding of biological invasions globally (Hulme et al. 2013), and limiting cooperative research on biological invasions among researchers from different countries and regions.

We hypothesized that the four studied species, considered as globally invasive plants of temperate zone, are likely to be studied evenly throughout their invaded ranges, and, as such, indexed by international databases. If so, combining the results of a literature search from the Scopus and Web of Science Core Collection (WoS CC) databases may help to form a modern and complete picture of the most important results for these four temperate plant invaders. We focused on these species because of their widespread distribution and frequently reported impacts. Summarizing what is known about a target species can be used to develop questions for future research. While in recent years, several important review papers on one or more of these species have been published (Kowarik \& Säumel 2007, Lambdon et al. 2008, Cierjacks et al. 2013, Sladonja et al. 2015, Vítková et al. 2017). A complete global systematic review has not yet been carried out on these species.

To document the global research on these important temperate invasive plants, we used a search approach on the Scopus and WoS CC databases. We used the meth- 
odology of systematic reviews, well established in biological and medical sciences, including ones introduced in ecology and conservation (Pullin \& Stewart 2006, Cook et al. 2013, 2017, Haddaway et al. 2015, Westgate \& Lindenmayer 2017, Januchowski-Hartley et al. 2018). Compared with traditional narrative reviews, systematic reviews exhibit many advantages, such as more comprehensive literature searches, more objective and transparent study selection, and contribution to update and generalize of data (Littell et al. 2008). We performed a systematic review with the goal of summarizing and categorizing the invasive biology literature on these four species throughout their invaded ranges.

We conducted a systematic review using two the most authoritative international databases, Scopus and Web of Science Core Collection. We aimed to: (1) conduct a broad search for Acer negundo, Fraxinus pennsylvanica, Ailanthus altissima, Robinia pseudoacacia invasion literature using both well-known databases; (2) qualitatively summarize the literature on their invasion including publication information, study area location, habitat studied and topic discussed; (3) determine the quality of journals where results on the invasion biology of $A$. negundo, $F$. pennsylvanica, A. altissima, $R$. pseudoacacia were published and indexed in international databases selected; and (4) based on our findings, propose areas for future study.

\section{Methods}

We generated a list of peer-reviewed journal articles, conference papers, book chapters, which assessed the invasion biology of target species using the WoS CC and Scopus databases (Figure 1).

To obtain field studies on Ailanthus altissima, Acer negundo, Robinia pseudoacacia, Fraxinus pennsylvanica published in WoS CC, on 23 April 2019 we used the specific search strings (Appendix A). Synonyms for the search were extracted from CABI (2018) database. We used all results from WoS CC citation indices. We then delimited the search by relevant research areas of study by using the "exclude" function for exclusion studies in the irrelevant fields (see Appendix A).

As an alternative, we used the search function in database Scopus. Although the search and exclusion options are not identical between the two databases, we used the same search terms. We carried out the Scopus search on 23 April 2019. Like WoS CC, we delimited the search by relevant areas of study by using the "Limit to" function to exclude studies in the all areas apart from: Agricultural and Biological Sciences OR Earth and Planetary Sciences OR Environmental Science.
Records identified initially by both databases: Ailanthus altissima: 509 (WoS CC, 249; Scopus, 260). Acer negundo: 204 (WoS CC, 85; Scopus, 119). Fraxinus pennsylvanica: 287 (WoS CC, 126; Scopus, 161). Robinia pseudoacacia: 675 (WoS CC, 307; Scopus, 368).

Records removed by WoS CC and Scopus "refine" functions to eliminate non-related topics: Ailanthus altissima: -57 (WoS CC, -42; Scopus, -15). Acer negundo: -16 (WoS CC, -11; Scopus, -5). Fraxinus pennsylvanica: -32 (WoS CC, -23; Scopus, -9). Robinia pseudoacacia: -129 (WoS CC, -55; Scopus, -74).

Records refined trough elimination of non-related topics: Ailanthus altissima: 452 (WoS CC, 207; Scopus, 245).

Acer negundo: 188 (WoS CC, 74; Scopus, 114).

Fraxinus pennsylvanica: 255 (WoS CC, 103; Scopus, 152). Robinia pseudoacacia: 546 (WoS CC, 252; Scopus, 294).

Records screened using title, abstract and/or full text with exclusion of duplicate papers):

Ailanthus altissima: -310 (WoS CC, -144; Scopus, -166).

Acer negundo: -107 (WoS CC, -39; Scopus, -68).

Fraxinus pennsylvanica: -233 (WoS CC, -95 ;

Scopus, -138).

Robinia pseudoacacia: -391 (WoS CC, -185 ; Scopus, -206).

\section{Records included in systematic review:}

Ailanthus altissima: 83 (WoS CC, 63 + Scopus, 79 - duplicates, 59).

Acer negundo: 48 (WoS CC, 35 + Scopus, 46 - duplicates, 33).

Fraxinus pennsylvanica: 14 (WoS CC, 8 + Scopus, 14 - duplicates, 8).

Robinia pseudoacacia: 96 (WoS CC, 67 + Scopus, 88 - duplicates, 59).

Figure 1: Diagram documenting search and inclusion process and criteria for the global systematic review of the invasion biology of four temperate tree species.

Slika 1: Iskalni kriteriji in proces vključevanja v globalni sistematični pregled invazivne biologije štirih drevesnih vrst.

Non-related publications were excluded by title, abstract and/or a careful reading of full text if necessary. We only included literature that reported on these species as invasive organisms in field studies in their invaded ranges, excluding laboratory, genetic and cytological studies, reviews, and other studies that did not record or study plants in their invaded ranges in the field. We also excluded studies that did not occur in natural or semi-natural systems, such as studies of the effects on agricultural crops.

We then extracted the following information from all remaining studies: (1) publication journal; (2) year of publication; (3) country in which the study was conducted; (4) location of study area within country; (5) coordi- 
nates of study location; (6) habitat in which the species of interest were found; and (7) focus of the study (see below).

We classified the studies included in our review into five focus categories: (1) testing a specific invasion mechanism; (2) studies devoted to the distribution and spread of the invasive species; (3) surveys focused on the control and management of the invaders; (4) impacts of the invaders on other organisms, the communities or the ecosystems; and (5) others (studies that do not fit into any of these focuses).

We used Google Maps (https://www.google.com/ maps) to locate the study areas according to their names and then specified their latitude and longitude. When study sites were identified by more than one location, we characterized each of them by their mid-point. We obtained these mid-points using the Geographic Midpoint Calculator (http://www.geomidpoint.com).

In addition, we compared the 2017 bibliometric data for included journals from the Scopus and WoS CC. For this purpose, we analyzed 2017 JCR Impact Factor (IF) of journals from WoS CC and 2017 SCImago Journal Rank (SJR) scores of journals from Scopus (available at http://www.scopus.com/). We then ranked all journals by quartiles of both databases to demonstrate the quality of journals dealing with the invasion biology of the four studied plant species.

\section{Results}

For Fraxinus pennsylvanica, we initially identified 287 records across the WoS CC and Scopus databases accessed. After refining, we reduced the records to 255 . We then excluded studies with unrelated topics, or those conducted in the laboratory or greenhouse, or those with genetic or molecular data, reviews and duplicates after reading abstracts and/or full texts, if needed. Eventually, we included 14 papers that meet our criteria, of which eight were from WoS CC, fourteen from Scopus (Figure 1 and see Appendix B). There was an overlap of eight records between tested databases, which were excluded from analysis at the last stage of selection.

Using our search terms, we initially identified 204 publications for Acer negundo across the both databases used, which were reduced to 188 after refining. We then perused the titles and abstracts and/or full texts (if needed) of the papers, and excluded records that were reviews, cell, molecular or genetic studies, or laboratory/ greenhouse experiments with potted plants, or unrelated topics. After excluding papers step by step, we obtained a total of 48 publications on $A$. negundo: 35 from WoS
CC, 46 from Scopus (Figure 1 and see Appendix C). There was an overlap of 33 records between WoS CC and Scopus.

For Robinia pseudacacia, 675 records were initially identified across the WoS CC and Scopus databases. After refining, we reduced the records to 546 . We then excluded studies with unrelated topics, or those conducted in the laboratory/greenhouse, those with unclear data, reviews and duplicates after reading abstracts and/or full texts (if needed). Eventually, we included 96 papers that met selected criteria, of which 67 were from WoS CC, 88 from Scopus (Figure 1 and see Appendix D). There was an overlap of 59 records between tested databases, which were excluded at the last stage of selection.

Using selected search terms, we initially identified 509 records for Ailanthus altissima across the both databases used, which were reduced to 452 after refining. We then investigated the titles and abstracts or full texts (if needed) of each of the papers, and excluded records conducted review articles, cell, molecular or genetic studies, or laboratory/greenhouse experiments with potted plants, or unrelated topics. After excluding papers step by step, we obtained a total of 83 publications devoted to A. altissima invasion: 63 from WoS CC, 79 from Scopus (Figure 1 and see Appendix E). There was an overlap of 59 records between WoS CC and Scopus, which were excluded from list of analyzed publications.

\section{Journals and years of publication}

The 14 papers on Fraxinus pennsylvanica invasion were published in 13 different journals and one book chapter. Of these 13 journals, nine were indexed in WoS CC, and all 13 journals - in Scopus. The 96 articles on Robinia pseudacacia were published in 54 different journals. Of these, 35 journals were indexed in WoS CC, 53 - in Scopus. The 48 papers on Acer negundo invasion were published in 31 different journals. Of these, 22 titles were indexed in WoS CC, and 31 journals were indexed in Scopus. The 83 papers on Ailanthus altissima invasion were published in 57 different journals. Of these, 45 titles were indexed in WoS CC, and 57 titles - in Scopus (Table 1).

The 14 papers on Fraxinus pennsylvanica identified by the databases and included in our review were published from 2005 to 2018 (Figure 2). Due to the small number of records for this species there was no discernible temporal trend for $F$. pennsylvanica invasion. The first study on Robinia pseudacacia was published in 1991. The remarkable increase in number of field studies started since 2009. The 48 articles on Acer negundo were published between 2003 and 2019 with highest number 
Table 1: The number of journals and publications identified through a global literature search from 1975 to late April 2019 using WoS CC and Scopus databases for invasion biology research on Ailanthus altissima, Acer negundo, Fraxinus pennsylvanica, and Robinia pseudacacia

Tabela 1: Število izbranih revij in publikacij v globalnem pregledu literature od leta 1975 in konec aprila 2019 v bazah podatkov WoS CC in Scopus o raziskavah invazivne biologije vrst Ailanthus altissima, Acer negundo, Fraxinus pennsylvanica, in Robinia pseudacacia

$\begin{array}{lccc}\text { Species } & \begin{array}{c}\text { No. of } \\ \text { journals }\end{array} & \begin{array}{c}\text { No. of } \\ \text { publications }\end{array} & \begin{array}{c}\text { Mean no. of } \\ \text { publications per } \\ \text { journal }(\mathrm{M} \pm \mathrm{m})\end{array}\end{array}$

\begin{tabular}{llll} 
Ailanthus altissima & 57 & 83 & $1.3 \pm 0.2$ \\
Acer negundo & 31 & 48 & $1.4 \pm 0.2$ \\
Robinia pseudoacacia & 54 & 96 & $1.6 \pm 0.2$ \\
Fraxinus pennsylvanica & 13 & 14 & $1.0 \pm 0.0$ \\
\hline
\end{tabular}

(87.5\%) in the period of 2010-2018. Curiously, the number of publications per year was relatively stable for this invader with a little increase since 2014 (Figure 2). Finally, our review included 83 papers on Ailanthus altissima which were published from 1994 to 2019. However, the greatest number of field studies (78.3\%) was published in 2008-2018 (Figure 2).

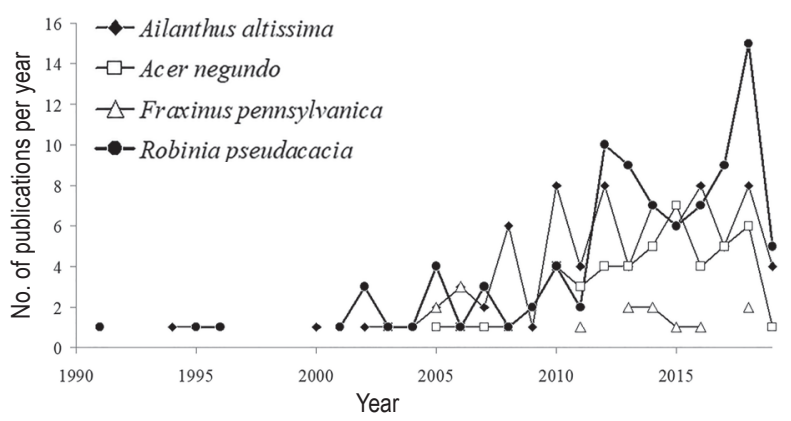

Figure 2: The number of publications per year. Global literature identified through a search from 1975 to late April 2019 using WoS $\mathrm{CC}$ and Scopus databases for invasion biology research on Ailanthus altissima, Acer negundo, Fraxinus pennsylvanica, and Robinia pseudacacia. Slika 2: Število publikacij na leto. Literaturni viri od leta 1975 do konca aprila 2019 v bazah WoS CC in Scopus o invazivni biologiji vrst Ailanthus altissima, Acer negundo, Fraxinus pennsylvanica in Robinia pseudacacia.

The 2017 JCR IF was available for 73 of the 80 journals included for all studied invasive species with exception of Acta Scientiarum Polonorum - Formatio Circumiectus, Journal of Central European Agriculture, Mathematical and Computational Forestry \& Natural-Resource Sciences, Poljoprivreda, Russian Journal of Biological
Invasions indexed in Emerging Sources Citation Index database, and Canadian Field-Naturalist, Ohio Journal of Science excluded from WoS CC after 2012 and 2008 , respectively. In general, 2017 IF JCR of all included journals varied between 0.300 (Lazaroa) and 7.828 (Ecological Monographs). Considering invaders targeted, we found no remarkable differences between mean values of 2017 IF JCR: $2.157 \pm 1.876,2.134 \pm 1.192$, $1.913 \pm 1.192,2.012 \pm 1.304$ for Ailanthus altissima, Acer negundo, Fraxinus pennsylvanica, Robinia pseudacacia, respectively. Of the 10886 Scopus titles, the journal Glasnik za Šumske Pokuse was excluded from analysis as discounted in the database after 2011, and Vestnik Tomskogo Gosudarstvennogo Universiteta, Biologiya does not still have SJR value because it has been included in Scopus database at June 2018. Among analyzed journals, 2017 SJR scores varied between 0.104 (Humans and Nature) and 4.912 (Ecological Monographs). Taking into account the separate invasive tree species, there were not remarkable differences between mean values of 2017 SJR: $0.922 \pm 1.033,0.834 \pm 0.841,0.834 \pm 0.841$, $0.664 \pm 0.574$ for $A$. altissima, $A$. negundo, F. pennsylvanica, $R$. pseudacacia, respectively. The arrangement of journals included in both databases showed that the largest number of field studies was published in Q1-journals followed by Q3-journals, and then other groups. It indicated the significance of different-level journals in highlighting the issues of biological invasions of these four alien tree species (Figure 3).

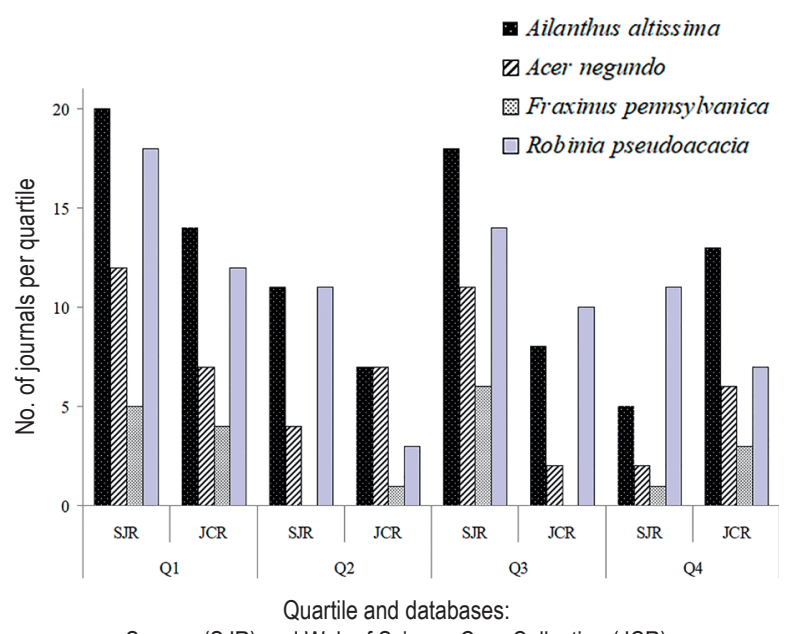

Scopus (SJR) and Web of Science Core Collection (JCR)

Figure 3: Number of journals per quartiles (Q1-Q4) of both databases (Scopus - 2017 SJR, Web of Science Core Collection - 2017 JCR IF) analyzed.

Figure 3: Število revij, razvrščenih v kvartile (Q1-Q4) v obeh analiziranih bazah podatkov (Scopus - 2017 SJR, Web of Science Core Collection - 2017 JCR IF). 


\section{Location of study areas, habitats and study focuses}

Based on analysis of records included, the presence of Fraxinus pennsylvanica as an invader was studied in 19 habitats as reported in 14 papers included in the analysis. At the same time, one paper did not provide any information on habitat preference. Habitats investigated included forests, grasslands, farmlands and roadsides (Figure 4). The largest number of studies across both databases on Acer negundo as an alien plant were in forest ecosystems, followed by roadsides, farmlands, and grasslands respectively, while seven articles didn't provide any data on habitat invaded (Figure 4). About half of all studies on Ailanthus altissima invasion (47.1\%) were conducted in forests. Around half of other studies were devoted to the invader records in either farmlands or roadsides, while 11 papers did not include information on habitat preference. The highest proportion (55.6\%) of studies on Robinia pseudoacacia invasion were also in forest ecosystems, while 12 papers did not provide any information on habitat invaded. Eleven to twenty one papers included data on its invasion in grasslands, roadsides and farmlands.

The most common focuses of the studies on Robinia pseudoacacia invasion were its impacts on and interaction with native species, populations and plant communities, and distribution and spread of the invader, followed by other focuses (Figure 5). Similar pictures were demonstrated for other three invaders with slight variations between the categories Distribution \& Spread and Impact $\&$ Interaction (Figure 5).

There were 44 locations, in which research on Acer negundo invasion was studied. Geographically, 38 study sites $(86.4 \%)$ were located in Europe (Figure 6B), while other six were located in Canada and Asia (Figure 6A). For Fraxinus pennsylvaica, only 15 areas were identified. Of these, $86.7 \%$ of the studies were conducted in Europe (Figure 7B). At the same time, one study was conducted in Eastern Africa (Kenya), and one - in Siberia (Figure 7A). The Robinia pseudoacacia invasion was studied in 143 locations (Figure 8A). There were two main clusters of records - East Asian (Figure 8C) with $22.4 \%$ of total number of locations (in China, South Korea, Japan, Russian Far East), and European - West Asian (Figure 8B) with 109 locations and with high numbers in Italy (20 sites), Slovakia (17 sites), Hungary (9 sites), Ukraine (8 sites), Croatia (7 sites), Slovenia (7 sites), Poland (6 sites). Interestingly, two studies on $R$. pseudoacacia invasion were conducted close to its native range - in United States of America (Figure 8A). For the East Asian Ailanthus altissima, 143 locations

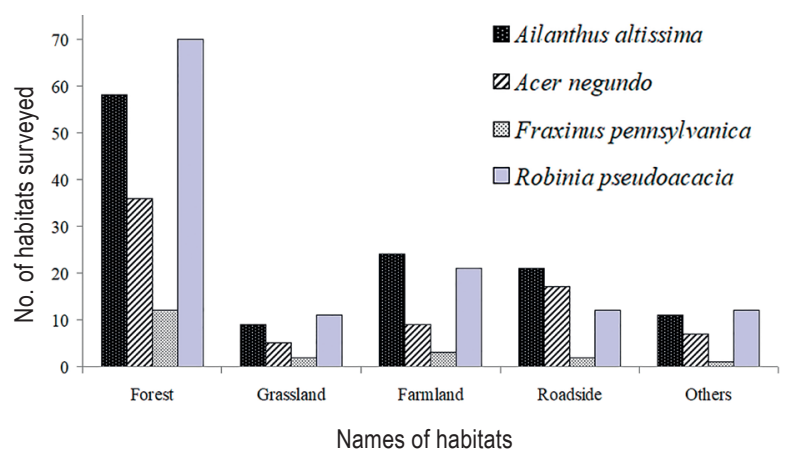

Figure 4: Habitats investigated (Plots include studies from Web of Science Core Collection and Scopus).

Slika 4: Preučevani habitati (ploskve vključujejo raziskave iz baz Web of Science Core Collection in Scopus).

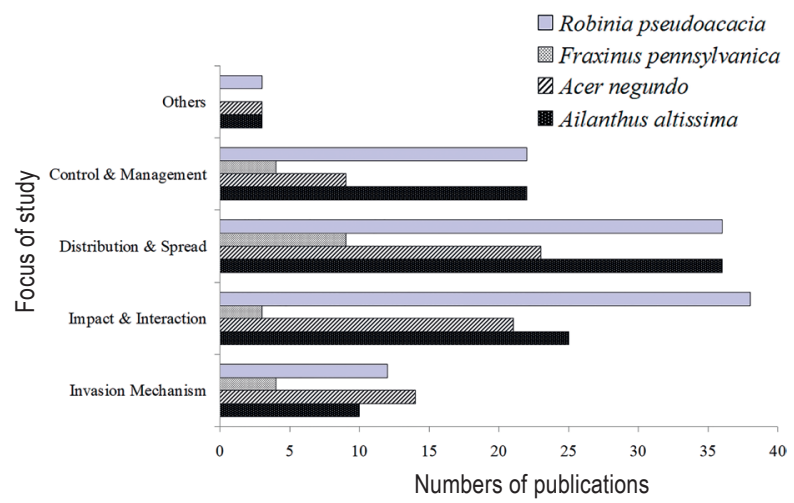

Figure 5: Focus of study (Plots include studies from Web of Science Core Collection and Scopus).

Figure 5: Namen raziskave (ploskve vključujejo raziskave iz baz Web of Science Core Collection in Scopus).

were identified. Of them, $44.7 \%$ of the studies were conducted in European countries - Slovenia (25 sites), Croatia (24 sites), Spain (7 sites), Italy (11 sites), Greece (7 sites); other countries were represented by lesser number of locations identified (Figure 9C). Also, 20.3\% locations were situated in USA (Figure 9B), while six sites were identified in Asia (Figure 9C). 

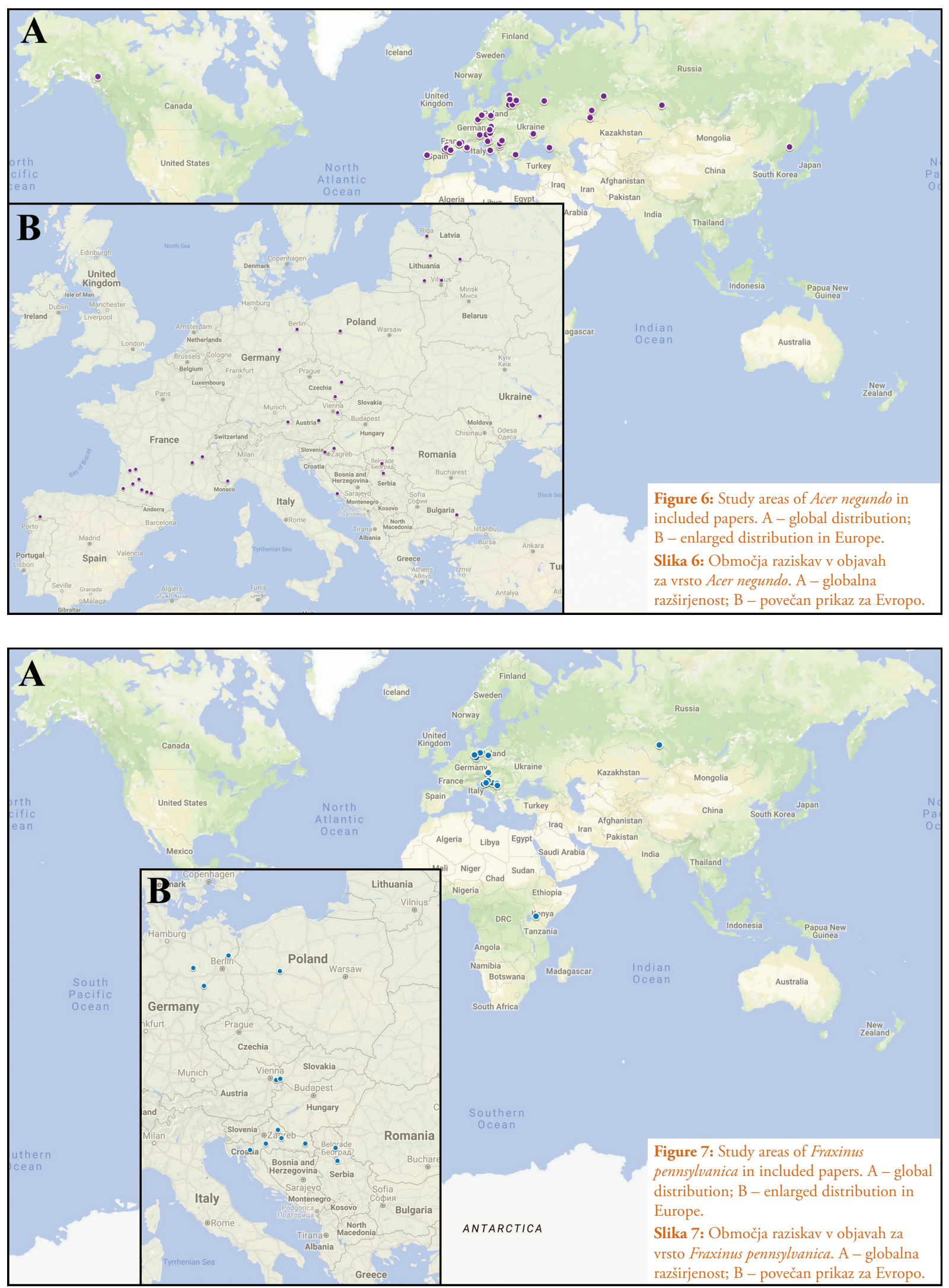


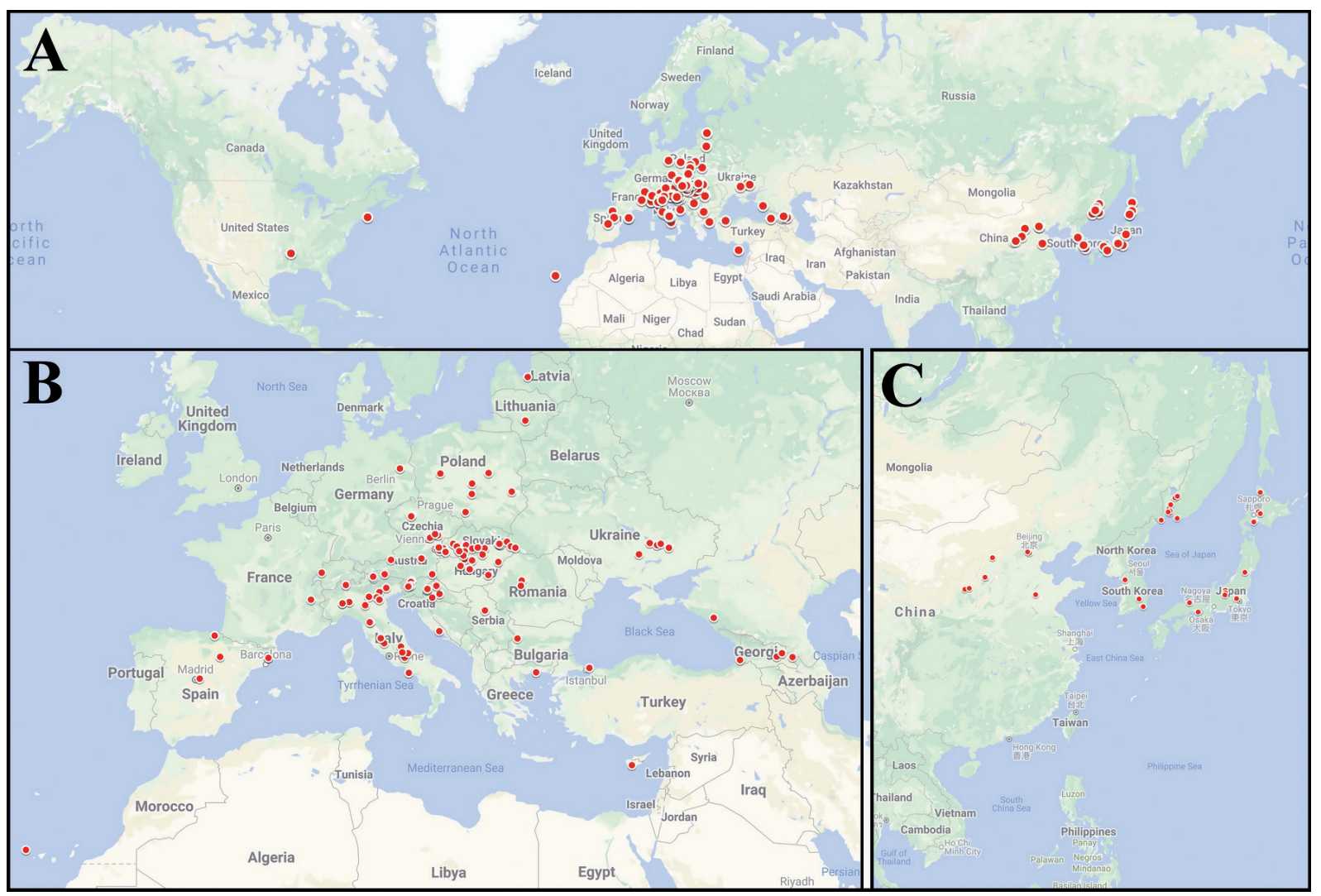

Figure 8: Study areas of Robinia pseudoacacia in included papers. A - global distribution; B - enlarged distribution in Europe and Western Asia; $\mathrm{C}$ - enlarged distribution in East Asia.

Slika 8: Območja raziskav v objavah za vrsto Robinia pseudoacacia. A - globalna razširjenost; B - povečan prikaz za Evropo in zahodno Azijo; $\mathrm{C}$ - povečan prikaz za vzhodno Azijo.

\section{Discussion}

Our systematic review documents evidence for the four invasive plant species considered as widely spread and aggressive invaders in the temperate zone of Eurasia and Northern Hemisphere as a whole. Undoubtedly, this undercounts areas where the species are invasive, because the analyzed databases, WoS and Scopus, do not include all studies. In addition, published research might not be conducted on these invaders in all areas where they are present. Finally, a systematic review, carried out across numerous international and regional scientific databases may offer insights into the general literature on plant invasions in both hemispheres.

Research investigating the biological invasions of Acer negundo, Ailanthus altissima, Robinia pseudoacacia has increased substantially in the $21^{\text {st }}$ century (Figure 2), while data on Fraxinus pennsylvanica invasions are insufficient to provide some conclusions. This tendency is similar to the results of recent scientific reviews on biological invasions in different ecosystems (Lowry et al. 2013, Stricker et al.
2015, Liebhold et al. 2017, Mačić et al. 2018). A large proportion of studies included in our systematic review for all invaders was conducted in areas located mainly in European countries (Figure 3), excluding, however, Eastern Europe from which there was a lack of field ecological studies published. This is particularly the case in the Russian Federation which is characterized by an extreme lack of field ecological studies on biological invasions in selected databases, despite of numerous national statements and publications (e.g. Black Data Books (Vinogradova et al. 2010, 2011, Notov et al. 2011, Vinogradova \& Kuprianov 2016)) and the presence of a specialized journal (Russian Journal of Biological Invasions) indexed in the Scopus and WoS CC (ESCI) databases. This is in accord with worldwide assessments of biological invasions recently published (Lowry et al. 2013, van Kleunen et al. 2015, Dawson et al. 2017, Pyšek et al. 2017, Seebens et al. 2017). Our knowledge of biological invasions may be biased due to the inaccessibility of publication records, either due to language restrictions or due to the non-indexing of journals by the more widely used databases (e.g. 


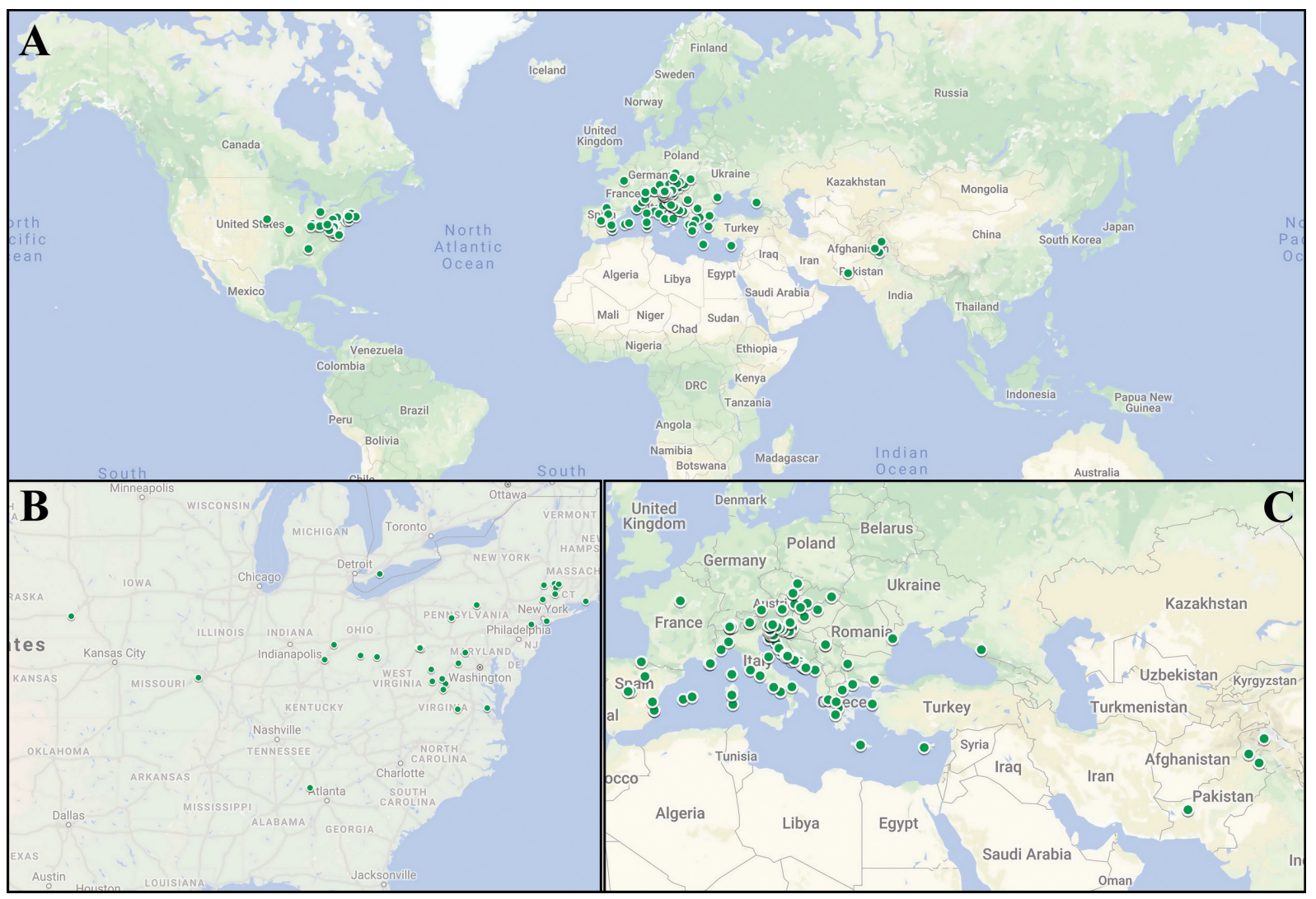

Figure 9: Study areas of Ailanthus altissima in included papers. A - global distribution; B - enlarged distribution in North America; C - enlarged distribution in Europe and Western Asia.

Slika 9: Območja raziskav v objavah za vrsto Ailanthus altissima. A - globalna razširjenost; B - povečan prikaz za Severno Ameriko; C - povečan prikaz za Evropo in zahodno Azijo.

Yu et al. 2016). Hence, to obtain the complete picture of studies, there is a need to involve national and regional bibliographic databases.

Across both the databases, a large number of these field studies on the four invasive species were conducted on bioinvasions in forests rather than along farmlands and roadsides, which are traditionally known to be favorable habitats for invasive species establishment (Yan et al. 2004, Hulme 2009). Hence, the selected alien plants can invade and then impact forested areas, as these invaders are recognized not only as naturalized plants, but often as transformers sensu Richardson (2000) (e.g., Vinogradova et al. 2010, Berg et al. 2017). However, this does not suggest that non-woodland habitats are not invaded severely.

Overall, a large percentage of studies measured the impacts of the invaders on either the native species, or the communities invaded. In this regard, we did not separately analyze Scopus- and WoS-indexed papers due to the insignificant differences between the both databases. Papers on invader distribution or evidence of the new records were also numerous for all selected alien species.
This indicates both the continuing spread and the high level of invasiveness of these alien trees in temperate zone of Eurasia and North America. Hence, we can expect on increasing the number of papers dealing with invaders' impact and their interactions with other organisms or ecosystems inhabited, as well as investigations on control and/or management of the invasive plants.

Based on the review of the quality of journals included in our systematic review, we conclude that most papers indexed in both databases were published in journals of $1^{\text {st }}(1 \mathrm{Q})$ and $3^{\text {rd }}(3 \mathrm{Q})$ quartiles, while $2^{\text {nd }}$ and $4^{\text {th }}$ quartiles are also presented by many journals dealing with different research fields. Among all journals included in review, there were five titles (NeoBiota, Preslia, Biological Invasions, Invasive Plant Science and Management, Russian Journal of Biological Invasions) indexed in WoS CC and/ or Scopus, which are specialized on publications devoted to biological invasions. The WoS CC journals are highquality titles of the $1^{\text {st }}$ or $2^{\text {nd }}$ quartiles, while Russian Journal of Biological Invasions is a journal of the SJR $3^{\text {rd }}$ quartile. Twenty-four papers were published in these journals. 
Thus, a significant percentage of papers on invasion of Acer negundo, Ailanthus altissima, Robinia pseudoacacia and Fraxinus pennsylvanica were published in specialized "bioinvasion-related" journals. However, a high number (32) of articles on these invaders were published in 14 forestry-related journals: Annals of Forest Science (SJR: Q1, JCR: Q1), Canadian Journal of Forest Research (SJR: Q1, JCR: Q2), Dendrobiology (SJR: Q2, JCR: Q3), Forest Ecology and Management (SJR: Q1, JCR: Q1), Forest Science (SJR: Q1, JCR: Q3), Forests (SJR: Q1, JCR: Q2), IForest (SJR: Q2, JCR: Q3), Journal of Forest Research (SJR: Q2, JCR: Q3), Journal of Forestry (SJR: Q1, JCR: Q1), New Forests (SJR: Q1, JCR: Q1), Small-Scale Forestry (SJR: Q2, JCR: Q3), Urban Forestry \& Urban Greening (SJR: Q1, JCR: Q1), Arboriculture and Urban Forestry (SJR: Q2), Journal of Forest Science (SJR: Q3), and Journal of the Japanese Forestry Society (SJR: Q4). Relatively low-quality (Q4) journals are almost absent. Publications on invasion biology of the four species are presented mainly by Q1-Q3 titles in both databases. Thus, we can assume that the choice of a journal for publication was more clearly reflected in the studied habitat (here is a forest as more preferable habitat for studied species, Figure 4), than in the study subject to biological invasions.

From this review, we show the utility of systematic reviews in both indicating and filling gaps in the literature. If a review is based on the international highest-quality databases, it is possible to identify a range of the most important and comprehensive studies within certain scopes, particularly related to biological invasions. It is obvious that in Eastern Europe and Russia, there is a need to include more bioinvasion-related studies in analyzed databases. It is also important to note that despite of the national statements on high-degree invasiveness of Acer negundo and Fraxinus pennsylvanica, there are relatively few studies of these species indexed in the WoS CC and Scopus databases. Therefore, it is urgent to fill large gaps in the knowledge on distribution these alien plants in invasive range.

Since the publication of Elton (1958), studies on research topics and ecological systems related to biological invasions differed in different parts of the world. In one area in our review, (mainly Western Europe and Eastern United States) there is a satisfactory investigation level, while Central Europe is characterized by higher level of knowledge on invasion of the tree species. Other areas present the white gaps in terms of invasion biology of the four studied tree species based on WoS CC and Scopus. In our view, the national peculiarities of research in different countries, the accumulation of the most results in national-language publications, and the underestimation of local and regional alien floras can explain these gaps. Thus, to obtain a full picture of biological invasions, it is necessary to take into account regional differences in study focuses, habitats invaded, and attempt to access non-English-language literature and a wider range of scientific regional and national databases. Finally, our review suggests a need to involve the wider range of literature in most underestimated regions, especially that which concerns research questions on poorly studied and/or most aggressive invaders within the framework of prevailing invasion hypotheses (Catford et al. 2009, Gurevitch et al. 2011). These actions will potentially broaden our knowledge and understanding of biological invasions worldwide.

\section{Species-specific insights}

Using publications included in the review for studies invasive trees, we generalized the most important data by focusing on habitat types invaded, factors influencing tree invasion, consequences of each invader impact on natural ecosystems, measures for counteracting plant invasions. For all species, we noted the higher invasiveness in urban habitats in comparison with natural and semi-natural ecosystems because last ones are more susceptible to plant invasions. Therefore, we focused on overview of invaders' features in natural ecosystems. Finally, we did not discuss the publications devoted to distribution and new records of invasive tree species.

\section{Acer negundo invasion}

Based on the identified studies, we can state that this species is considerably more confined to both natural (Tabacchi et al. 2003, Lamarque et al. 2012) and urban (Straigytè et al. 2015) riparian forest ecosystems. Acer negundo not only invaded riparian zones, but also forms Acer-dominated forest communities on the place of former riparian phytocenoses.

Acer negundo represented a well competitive advantage over native species by showing both a high survival in the shade and a high growth in full light habitats (Saccone et al. 2010a). Saccone et al. (2010b) demonstrated that tree and shrub canopy of Salix and then of Acer negundo itself facilitated the survival and establishment of invader by negative affecting of herb layer acting as a suppressor of Acer negundo invasion (Saccone et al. 2013). Additionally, Acer negundo negatively affected the abundance of seedlings from soil seed bank in invaded habitat (Veselkin et al. 2018).

Concerning a role of environmental factors, the water was the most impactful factor determining invader 
survival, more specifically precipitation during certain months (Zajpler et al. 2018), habitat moisture (Dyakov \& Zhelev 2013). Säumel \& Kowarik (2013) demonstrated importance of hydrochory as a dispersal vector for the invader in urban riparian ecosystems.

Among counteracting measures used to control this invader in secondary range, destroying spontaneous seedlings seems to be more preferable since cutting of the grown trees was not effective as the species can re-grow from the stumps (Valantinaite et al. 2011). Also, at a local scale, Merceron et al. (2016) showed higher effectiveness of the yearly repeated girdling, and removing seedlings of the invader from understory layer when applying girdling on adult and sapling individuals for induction of higher mortality of Acer negundo. For urban ecosystems, Säumel \& Kowarik (2010) demonstrated that a risk of Acer negundo invasion could be prevented with help of planting native tree species along river corridors. Kostina et al. (2016) suspected that progressing affection of $A$. negundo leaves by fungus Phyllosticta negundinis and noninfectious leaf toxicosis can decrease its invasive potential.

\section{Fraxinus pennsylvanica}

By generalizing data on Fraxinus pennsylvanica in secondary range, we noted a large number of publications (95.1\% of total number of ones initially identified from both databases) excluded from the analysis. The use of key words "invasion", "alien" often led to the selection of high number of publications, which did not aim studying its invasion in secondary range. As a rule, the mentioned cases could be explained by the fact that in its native range, F. pennsylvanica is affected by the invasive insect the emerald ash borer (Agrilus planipennis Fairmaire, 1888) (e.g. Flower et al. 2018). From one side, it would be guessed that Agrilus planipennis may act as biotic agent against Fraxinus pennsylvanica invasion. However, Orlova-Bienkowskaja (2014) demonstrated that in West Russia the emerald ash borer damaged both invasive Fraxinus pennsylvanica and, although in lesser degree, native Fraxinus excelsior L. Thus, there are already two issues - invasive tree invaded by invasive insect, which need to be considered nowadays.

Concerning Fraxinus pennsylvanica invasion in secondary range, fourteen field studies identified in result of analysis were concentrated predominantly in Central Europe. Although the invader can inhabit different forest types, $F$ pennsylvanica invades predominantly floodplains. The confinement of $F$. pennsylvanica to floodplains is also related to its enhanced regeneration in flooded areas and the increase in seed germination rate with the duration of the inundation (Schmiedel \& Tackenberg 2013). A threat to natural ecosystems in Croatia and Poland also demonstrated on the basis of radial growth rates studies (e.g. Zajpler et al. 2018) with a lack of floristic and phytosociological studies (e.g. Mullah et al. (2014) in Kenya, and Kremer et al. (2006b) in Croatia). However, as a result of one of field studies, new Fraxinus pennsylvanica-formed syntaxon was described (Batanjski et al. 2015). Despite the recognized negative role of the invader, its useful role in management and amelioration of habitats is sometimes underlined (e.g. Kremer \& Čavlović 2005).

As the most effective measure to counteract the $F$. pennsylvanica invasion was the removal single trees and seedlings of the invader and from plantation with short rotations (Kremer et al. 2006a, Drescher \& Prots 2016).

\section{Robinia pseudoacacia}

The highest number of identified studies demonstrated $R$. pseudoacacia invasion in forest ecosystems (Figure 4). This can be manifested either in forming of invader-dominated forest on the place of abandoned agricultural lands (Sitzia et al. 2018) or in its penetration in different existing forest ecosystems. The European mixed oak-hornbeam forest was recognized as the forest type most influenced by replacement with $R$. pseudoacacia, whereas floodplain forest was changed the least (Slabejová et al. 2019), although many of analyzed studies of $R$. pseudoacacia invasion were conducted exactly in floodplain forests. At the same time, Çoban et al. (2019) demonstrated that total invasion cover was considerably higher on the clear-cut area compared with the forest area and did not make a significant effect on forest interior species. This is consistent with statement that the invasion severity into the forest depth decreases with increase of the distance from forest edge in Protected Areas (Slodowicz et al. 2018).

Robinia pseudoacacia invasion affects numerous different components of natural ecosystems, first of all, the content of soil nitrogen causing many of consequent modifications (e.g. Staska et al. 2014). The invaded forests are characterized by increase of bacterial richness, decrease of abundance and richness of arthropods, richness of nematodes, and richness and diversity of plant communities (Lazzaro et al. 2018), change in plant species diversity (Benesperi et al. 2012) and even local bird species composition (Hanzelka \& Reif 2015). Berg et al. (2017) demonstrated strong affecting forest communities by $R o$ binia pseudoacacia as a result of building up high mean cover values in these habitats. However, in contrary to the most of analyzed studies, Masaka et al. (2013) found no statistical differences in number of understory plant species between Robinia pseudaocacia plantations and white birch plantations in Japan, as well as Sitzia et al. (2012) 
found no evidence that the presence of $R$. pseudaocacia in secondary stands plays a major role in shaping the diversity of the understory plant groups compared to native stands. So large number of contradictions in research results of $R$. pseudoacacia influence on invaded ecosystems indicates its comprehensive and still difficultly recognized nature, which requires further studies.

Concerning ecological factors, Robinia pseudoacacia was capable to grow in a wide range of water availability gradient in Spain (Nadal-Sala et al. 2013). However, a lack of moisture had negative effect on $R$. pseudoacacia in China (Wei et al. 2018). Finally, Terwei et al. (2013) demonstrated that under the closed canopy inside the forest stands, i.e. with a lack of light, $R$. pseudoacacia regenerated very scarcely.

Among measures to control Robinia pseudoacacia invasion, the cutting of invader's canopy trees can be successfully applied to counteract its invasion in riparian forest ecosystems (Sakio 2003). According to Masaka et al. (2015), R. pseudoacacia trees should be cut during the dormant season to facilitate coppicing and in the summer to facilitate control or removal with additional conservation of herbaceous vegetation cover, together with consecutive sprout clipping, will aid the complete removal of the invasive species. Buffer zones around forests were suggested as a very effective passive method in controlling $R$. pseudocacia invasion (Crosti et al. 2016). An interesting way was suggested by Motta et al. (2009) who noted that the best strategy to control the $R$. pseudoacacia spread is to support conditions favorable for its colonization, and to wait for natural suppression of the tree invader by other trees.

\section{Ailanthus altissima invasion}

The generalization of the entire set of identified studies allowed considering Ailanthus altissima as a highly invasive tree species in Europe (e.g. Constán-Nava et al. 2015), while in North America it seems to be less aggressive, but also requiring attention (e.g. Kasson et al. 2013). It can form monodominant secondary forest and invade successfully natural forest communities. Höfle et al. (2014) demonstrated that among softwood and hardwood forests, $A$. altissima more frequently colonizes hardwood floodplain forests. Berg et al. (2017) showed that A. altissima also rare invaded montane beech forests, coniferous mountain forests and forests at extremely dry sites, swamp and bog forests dominated by willows and ash. Within all forest types, it has higher invasion activity along fire-damaged and opened areas (Kowarik 1995), thus exhibiting a "gapobligate" strategy of forest recruitment (Knapp \& Canham 2000). Obviously, Ailanthus altissima benefits from a loss of its competitors in forest communities. At a local scale, the invader is not evenly distributed in forests. So, the number of A. altissima stems and its basal area decreased with increased distance from the woodlot edge (Espenschied-Reilly \& Runkle 2008), although the relatively low light conditions are sufficient for the growth and survival of generative regeneration of A. altissima at early development stages (Knüsel et al. 2017).

The invasion rate of this wind-dispersal can be increased, if its populations border roadsides and could serve as seed sources for further local and landscape spread (McAvoy et al. 2012). Allocation of A. altissima populations along water courses may contribute for longdistance dispersal more than two orders of magnitude farther than recorded primary dispersal due to the retained high seed germination rates even after five months in the water (Kaproth \& McGraw 2008). By considering forest ecosystems, A. altissima invasion is also supported and intensified by fresh clear-cuts, especially repeated ones (Radtke et al. 2013).

Despite the generally high preference to forest ecosystems, some studies indicated the higher invasiveness of Ailanthus altissima in coastal forest ecosystems (Novak \& Novak 2018), which are obviously characterized by more mild and perhaps favorable climatic conditions. This assumption is partially supported by data on spatial distribution of $A$. altissima in a local scale (Slovenia), where the tree species invades more actively forest communities that appear in warm areas with pronounced climatic seasonality (Čarni et al. 2017). The distribution of studies identified in the review (Figure 9) can additionally indicate that A. altissima is more abundant in coastal areas, and seems to be occasional in the depths of mainland.

Together with Robinia pseudoacacia, Ailanthus altissima strongly affected forest communities of invaded sites due to the building up high mean cover values in invaded forests (Berg et al. 2017) and seedling success in canopy gaps and the formation of persistent clumps of clonal sprouts around canopy trees (Espenschied-Reilly \& Runkle 2008). Concerning forest biota, the invasion of $A$. altissi$m a$ in France associated to lower soil microbial activity, decreasing abundance of litter Acari and Collembola, and aboveground predatory Coleoptera, and decreasing terrestrial Gastropoda species richness. At the same time, the increased A. altissima density corresponded with greater abundance of litter Lumbricidae and aboveground coprophagous Coleoptera (Motard et al. 2015).

Among all four studied invasive tree species, Ailanthus altissima had the highest diversity of studies devoted to control its invasion. The herbicide imazapyr together with prescribed burn treatment seems to be one of the most effective ways in killing large saplings and trees of Ailanthus altissima. In addition, the late growing season 
application of imazapyr was highly effective in killing the invader and subsequent sprouts (Rebbeck et al. 2019). The cut stump and glyphosate treatment have been considered as the most effective and efficient in its control of young $A$. altissima shoots because it limits disturbance and has acceptable capital and operating costs, while the EZJect Capsule Injection System (using glyphosate) was effective at managing mature, seed-producing shoots, although last method had higher capital costs (Meloche \& Murphy 2006, Constán-Nava et al. 2010). The counteracting measures could include a combination of mechanical (e.g. cutting) and chemical (e.g. stem injection) means (Ferrero \& Vidotto 2015). In favor of this, Burch \& Zedaker (Burch \& Zedaker 2003) also noticed the preferred role of herbicides for controlling Ailanthus altissina invasion because they successfully kill the trees and prevents resprouting. As a biotic controlling factor, Harris et al. (2013) proposed the recently isolated strain of the fungus Verticillium albo-atrum causing near 100\% mortality of Ailanthus altissima in laboratory and field tests, and thus this fungus appears to be a promising tool in targeted control of the invasive tree species.

\section{Conclusions}

The generalization of analyzed studies demonstrated a higher habitat confinement of all species to forest systems. Among these, Ailanthus altissima and Robinia pseudoacacia were recognized as the most aggressive invaders, which are able to modify invaded habitats, change their environmental conditions, as well as form new secondary forest communities. At the same time, Acer negundo and Fraxinus pennsylvanica were less impactful invasive species, since they are able to penetrate into a limited number of habitats. The physical removal (cutting) of single trees and seedlings, sometimes together with chemical impact methods and prescribed burning were recognized as the most effective counteracting measures.

Despite the undoubted significance of WoS CC and Scopus databases for searching and accumulation of most important data, the use of only these sources is not sufficient to generalize the complete data about the invasion biology of certain alien plant species. It especially concerns the regions outside of North America and Western Europe. A large portion of important information on distribution, invasion success, invasion biology and ecology of alien plant species is obviously stored in national, non-English, databases. We propose the necessity to use additionally other, English or non-English-language, regional databases to conduct most comprehensive systematic reviews on invasion biology of certain alien plants.

\section{Acknowledgements}

I am grateful to two anonymous reviewers for their constructive and valuable comments and feedback on an earlier version of this review paper.

Anatoly Khapugin Di, https://orcid.org/0000-0002-6059-2779

\section{References}

Batanjski, V., Kabaš, E., Kuzmanović, N., Vukojičić, S., Lakušić, D. \& Jovanović, S. 2015: New invasive forest communities in the riparian fragile habitats: The case study from Ramsar site Carska bara (Vojvodina, Serbia). Sumarski List 139(3-4): 155-169.

Bellard, C., Thuiller, W., Leroy, B., Genovesi, P., Bakkenes, M. \& Courchamp, F. 2013: Will climate change promote future invasions? Global Change Biology 19(12): 3740-3748. https://doi.org/10.1111/ gcb. 12344

Benesperi, R., Giuliani, C., Zanetti, S., Gennai, M., Mariotti Lippi, M., Guidi, T., Nascimbene, J. \& Foggi, B. 2012: Forest plant diversity is threatened by Robinia pseudoacacia (black-locust) invasion. Biodiversity and Conservation 21(14): 3555-3568. https://doi. org/10.1007/s10531-012-0380-5

Berg, C., Drescher, A. \& Essl, F. 2017: Using relevé-based metrics to explain invasion patterns of alien trees in temperate forests. Tuexenia 37(1): 127-142. https://doi.org/10.14471/2017.37.012

Bottollier-Curtet, M., Charcosset, J.Y., Poly, F., Planty-Tabacchi, A. \& Tabacchi, E. 2011: Light interception principally drives the understory response to boxelder invasion in riparian forests. Biological Invasions 14(7): 1445-1458. https://doi.org/10.1007/s10530-011-0170-0

Burch, P.L. \& Zedaker, S.M. 2003: Removing the invasive tree Ailanthus altissima and restoring natural cover. Journal of Arboriculture 29(1): 18-24.

CABI. 2018: Invasive Species Compendium. CAB International, Wallingford, UK. Retrieved 26.12.2018 from www.cabi.org/isc

Carboneras, C., Genovesi, P., Vilà, M., Blackburn, T.M., Carrete, M., Clavero, M., D’hondt, B., Orueta, J.F., Gallardo, B., Geraldes, P., González-Moreno, P., Gregory, R.D., Nentwig, W., Paquet, J., Pyšek, P., Rabitsch, W., Ramírez, I., Scalera, R., Tella, J.L., Walton, P. \& Wynde, R. 2018: A prioritised list of invasive alien species to assist the effective implementation of EU legislation. Journal of Applied Ecology 55(2): 539-547. https://doi.org/10.1111/1365-2664.12997

Čarni, A., Mastnak Juvan, N., Dakskobler, I., Kutnar, L., Marinšek, A. \& Šilc, U. 2017: Prediction of the appearance of tree of heaven in forest communities in western Slovenia. Periodicum Biologorum 119(4): 261-283. https://doi.org/10.18054/pb.v119i4.4483

Catford, J.A., Jansson, R. \& Nilsson, C. 2009: Reducing redundancy in invasion ecology by integrating hypotheses into a single theoretical framework. Diversity and Distributions 15(1): 22-40. https://doi. org/10.1111/j.1472-4642.2008.00521.x

Cierjacks, A., Kowarik, I., Joshi, J., Hempel, S., Ristow, M., Lippe, M. \& Weber, E. 2013: Biological Flora of the British Isles: Robinia pseudoacacia. Journal of Ecology 101(6): 1623-1640. https://doi. org/10.1111/1365-2745.12162 
Coban, S., Balekoğlu, S. \& Özalp, G. 2019: Change in plant species composition on powerline corridor: a case study. Environmental Monitoring and Assessment 191(4): 200. https://doi.org/10.1007/ s10661-019-7341-3

Constán-Nava, S., Bonet, A., Pastor, E. \& Lledó, M.J. 2010: Longterm control of the invasive tree Ailanthus altissima: Insights from Mediterranean protected forests. Forest Ecology and Management 260(6): 1058-1064. https://doi.org/10.1016/j.foreco.2010.06.030

Constán-Nava, S., Soliveres, S., Torices, R., Serra, L., Bonet, A. 2015: Direct and indirect effects of invasion by the alien tree Ailanthus altissima on riparian plant communities and ecosystem multifunctionality. Biological Invasions 17(4): 1095-1108.

Cook, C.N., Nichols, S.J., Webb, J.A., Fuller, R.A. \& Richards, R.M. 2017: Simplifying the selection of evidence synthesis methods to inform environmental decisions: A guide for decision makers and scientists. Biological Conservation 213: 135-145. https://doi. org/10.1016/j.biocon.2017.07.004

Cook, C.N., Possingham, H.P. \& Fuller, R.A. 2013: Contribution of Systematic Reviews to Management Decisions. Conservation Biology 27(5): 902-915. https://doi.org/10.1111/cobi.12114

Crosti, R., Agrillo, E., Ciccarese, L., Guarino, R., Paris, P. \& Testi, A. 2016: Assessing escapes from short rotation plantations of the invasive tree species Robinia pseudoacacia L. in Mediterranean ecosystems: A study in central Italy. IForest 9(5): 822-828. https://doi.org/10.3832/ ifor1526-009

Dawson, W., Moser, D., van Kleunen, M., Kreft, H., Pergl, J., Pyšek, P., Weigelt, P., Winter, M., Lenzner, B., Blackburn, T.M., Dyer, E.E., Cassey, P., Scrivens, S.L., Economo, E.P., Guénard, B.S., Capinha, C., Seebens, H., García-Díaz, P., Nentwig, W., GarcíaBerthou, E., Casal, C., Mandrak, N.E., Fuller, P., Meyer, C. \& Essl, F. 2017: Global hotspots and correlates of alien species richness across taxonomic groups. Nature Ecology \& Evolution 1: 0186. https://doi. org/10.1038/s41559-017-0186

Drescher, A. \& Prots, B. 2016: Fraxinus pennsylvanica - an invasive tree species in Middle Europe: case studies from the Danube basin. Contributii Botanice 51: 55-69.

Dyderski, M.K. \& Jagodziński, A.M. 2018: Drivers of invasive tree and shrub natural regeneration in temperate forests. Biological Invasions 20(9): 2363-2379. https://doi.org/10.1007/s10530-018-1706-3

Dumalisile, L. \& Somers, M.J. 2017: The effects of an invasive alien plant (Chromolaena odorata) on large African mammals. Nature Conservation Research 2(4): 102-108. https://doi.org/10.24189/ ncr.2017.048

Dyakov, N. \& Zhelev, P. 2013: Alien species invasion and diversity of riparian forest according to environmental gradients and disturbance regime. Applied Ecology and Environmental Research 11(2): 249-272. https://doi.org/10.15666/aeer/1102_249272

Elton, C.S. 1958: The ecology of invasions by animals and plants. Methuenn, London. $181 \mathrm{pp}$.

Espenschied-Reilly, A.L. \& Runkle, J.R. 2008: Distribution and changes in abundance of Ailanthus altissima (Miller) Swingle in a southwest Ohio woodlot. Ohio Journal of Science 108(2): 16-22.

Fateryga, V.V. \& Bagrikova, N.A. 2017: Invasion of Opuntia humifusa and $O$. phaeacantha (Cactaceae) into plant communities of the Karadag Nature Reserve. Nature Conservation Research 2(4): 26-39. https://doi.org/10.24189/ncr.2017.011
Ferrero, A. \& Vidotto, F. 2015: Control of three-of-heaven (Ailanthus altissima) in the fortress "Cittadella" of Alessandria. Italian Botanist 47(2): 381-382.

Flower, C.E., Lynch, D.J., Knight, K.S. \& Gonzalez-Meler, M.A. 2018: Biotic and abiotic drivers of sap flux in mature green ash trees (Fraxinus pennsylvanica) experiencing varying levels of emerald ash borer (Agrilus planipennis) infestation. Forests 9(6): 301. https://doi. org/10.3390/f9060301

Gurevitch, J., Fox, G.A., Wardle, G.M., Inderjit \& Taub, D. 2011: Emergent insights from the synthesis of conceptual frameworks for biological invasions. Ecology Letters 14(4): 407-418. https://doi. org/10.1111/j.1461-0248.2011.01594.x

Haddaway, N., Woodcock, P., Macura, B. \& Collins, A. 2015: Making literature reviews more reliable through application of lessons from systematic reviews. Conservation Biology 29(6): 1596-1605. https:// doi.org/10.1111/cobi.12541

Hanzelka, J. \& Reif, J. 2015: Responses to the black locust (Robinia pseudoacacia) invasion differ between habitat specialists and generalists in central European forest birds. Journal of Ornithology 156(4): 1015-1024. https://doi.org/10.1007/s10336-015-1231-4

Harris, P.T., Cannon, G.H., Smith, N.E. \& Muth, N.Z. 2013: Assessment of plant community restoration following Tree-of-Heaven (Ailanthus altissima) control by Verticillium albo-atrum. Biological Invasions 15(9): 1887-1893. https://doi.org/10.1007/s10530-0130430-2

Höfle, R., Dullinger, S., Essl, F. 2014: Different factors affect the local distribution, persistence and spread of alien tree species in floodplain forests. Basic and Applied Ecology 15(5): 426-434. https://doi. org/10.1016/j.baae.2014.07.007

Hulme, P.E. 2009: Trade, transport and trouble: managing invasive species pathways in an era of globalization. Journal of Applied Ecology 46(1): 10-18. https://doi.org/10.1111/j.1365-2664.2008.01600.x

Hulme, P.E., Pyšek, P., Jarošík, V., Pergl, J., Schaffner, U. \& Vilà, M. 2013: Bias and error in understanding plant invasion impacts. Trends in Ecology \& Evolution 28: 212-218. https://doi.org/10.1016/j. tree.2012.10.010

Januchowski-Hartley, S.R., Adams, V.M. \& Hermoso, V. 2018: The need for spatially explicit quantification of benefits in invasive-species management. Conservation Biology 32(2): 287-293. https://doi. $\operatorname{org} / 10.1111 /$ cobi. 13031

Kaproth, M.A. \& McGraw, J.B. 2008: Seed viability and dispersal of the wind-dispersed invasive Ailanthus altissima in aqueous environments. Forest Science 54(5): 490-496.

Kasson, M.T., Davis, M.D. \& Davis, D.D. 2013: The Invasive Ailanthus altissima in Pennsylvania: A Case Study Elucidating Species Introduction, Migration, Invasion, and Growth Patterns in the Northeastern US. Northeastern Naturalist 20: 1-60.

Knapp, L.B., Canham, C.D. 2000: Invasion of an old-growth forest in New York by Ailanthus altissima: Sapling growth and recruitment in canopy gaps. Journal of the Torrey Botanical Society 127(4): 307-315. https://doi.org/10.2307/3088649

Knüsel, S., De Boni, A., Conedera, M., Schleppi, P., Thormann, J.J., Frehner, M. \& Wunder, J. 2017: Shade tolerance of Ailanthus altissima revisited: novel insights from southern Switzerland. Biological Invasions 19(2): 455-461. https://doi.org/10.1007/s10530-016-1301-4 
Kostina, M.V., Yasinskaya, O.I., Barabanshchikova, N.S. \& Orlyuk, F.A. 2016: Toward a issue of box elder invasion into the forests around Moscow. Russian Journal of Biological Invasions 7(1): 47-51. https:// doi.org/10.1134/S2075111716010069

Kowarik, I. 1995: Clonal growth in Ailanthus altissima on a natural site in West Virginia. Journal of Vegetation Science 6(6): 853-856. https:// doi.org/10.2307/3236399

Kowarik, I. \& Säumel, I. 2007: Biological Flora of Central Europe: Ailanthus altissima (Mill.) Swingle. Perspectives in Plant Ecology, Evolution and Systematics 8: 207-237. http://doi.org/10.1016/j. ppees.2007.03.002

Kremer, D. \& Čavlović, J. 2005: Distribution of introduced North American ash species and their role in lowland forest management in Croatia. Journal of Forestry 103(6): 309-313.

Kremer, D., Čavlović, J. \& Bozic, M. 2006a: Growth characteristics of introduced green ash (Fraxinus pennsylvanica Marshall) and narrowleaved ash ( $F$. angustifolia L.) in lowland forest region in Croatia. New Forests 31(2): 211-224. https://doi.org/10.1007/s11056-005-5176-y

Kremer, D., Pernar, R. \& Ančić, M. 2006b: Distribution of North American ash species in the Drava River basin and Danube basin (Croatia). Acta Botanica Croatica 65(1): 57-66

Lamarque, L.J., Delzon, S., Sloan, M.H. \& Lortie, C.J. 2012: Biogeographical contrasts to assess local and regional patterns of invasion: A case study with two reciprocally introduced exotic maple trees. Ecography 35(9): 803-810. https://doi.org/10.1111/j.16000587.2011.07300.x

Lambdon, P.W., Pyšek, P., Basnou, C., Arianoutsou, M., Essl, F., Hejda, M., Jarošík, V., Pergl, J., Winter, M., Anastasiu, P., Andriopoulos, P., Bazos, I., Brundu, G., Celesti-Grapow, L., Chassot, P., Delipetrou, P., Jogan, N., Josefsson, M., Kark, S., Klotz, S., Kokkoris, Y. \& Kühn, I. 2008: Alien flora of Europe: species diversity, temporal trends, geographical patterns and research needs. Preslia 80: 101-149.

Lazzaro, L., Mazza, G., d'Errico, G., Fabiani, A., Giuliani, C., Inghilesi, A.F., Lagomarsino, A., Landi, S., Lastrucci, L., Pastorelli, R., Roversi, P.F., Torrini, G., Tricarico, E. \& Foggi, B. 2018: How ecosystems change following invasion by Robinia pseudoacacia: Insights from soil chemical properties and soil microbial, nematode, microarthropod and plant communities. Science of the Total Environment 622-623: 1509-1518. https://doi.org/10.1016/j. scitotenv.2017.10.017

Liebhold, A.M., Brockerhoff, E.G., Kalisz, S., Nuñez, M.A., Wardle, D.A. \& Wingfield, M.J. 2017: Biological invasions in forest ecosystems. Biological Invasions 19(11): 3437-3458. https://doi. org/10.1007/s10530-017-1458-5

Littell, J.H., Corcoran, J. \& Pillai, V.K. 2008: Systematic reviews and meta-analysis. Oxford University Press, Oxford, New York, NY. https://doi.org/10.1093/acprof:oso/9780195326543.001.0001

Lowry, E., Rollinson, E.J., Laybourn, A.J., Scott, T.E., AielloLammens, M.E., Gray, S.M., Mickley, J. \& Gurevitch, J. 2013: Biological invasions: a field synopsis, systematic review, and database of the literature. Ecology and Evolution 3(6): 1835. http://doi. org/10.1002/ece 3.431

Mačić, V., Albano, P.G., Almpanidou, V., Claudet, J., Corrales, X., Essl, F., Evagelopoulos, A., Giovos, I., Jimenez, C., Kark, S., Marković, O., Mazaris, A.D., Ólafsdóttir, G.Á., Panayotova, M., Petović, S.,
Rabitsch, W., Ramdani, M., Rilov, G., Tricarico, E., Vega Fernández, T., Sini, M., Trygonis, V. \& Katsanevakis, S. 2018: Biological Invasions in Conservation Planning: A Global Systematic Review. Frontiers in Marine Science 5: 178. https://doi.org/10.3389/fmars.2018.00178

Masaka, K., Yamada, K., Sato, H., Torita, H. \& Kon, H. 2013: Understory plant richness and native tree invasion in exotic Robinia pseudoacacia stands in Hokkaido, Japan. Forest Science 59(5): 589-597. https://doi.org/10.5849/forsci.11-106

Masaka, K., Torita, H., Kon, H. \& Fukuchi, M. 2015: Seasonality of sprouting in the exotic tree Robinia pseudoacacia L. in Hokkaido, northern Japan. Journal of Forest Research 20(4): 386-395. https:// doi.org/10.1007/s10310-015-0488-z

McAvoy, T.J., Snyder, A.L., Johnson, N., Salom, S.M. \& Kok, L.T. 2012: Road survey of the invasive tree-of-heaven (Ailanthus altissima) in Virginia. Invasive Plant Science and Management 5(4): 506-512. https://doi.org/10.1614/IPSM-D-12-00039.1

Meloche, C. \& Murphy, S.D. 2006: Managing tree-of-heaven (Ailanthus altissima) in parks and protected areas: A case study of Rondeau Provincial Park (Ontario, Canada). Environmental Management 37(6): 764-772. https://doi.org/10.1007/s00267-0030151-x

Merceron, N.R., Lamarque, L.J., Delzon, S. \& Porté, A.J. 2016: Killing it softly: Girdling as an efficient eco-friendly method to locally remove invasive Acer negundo. Ecological Restoration 34(4): 297-305. https://doi.org/10.3368/er.34.4.297

Motard, E., Dusz, S., Geslin, B., Akpa-Vinceslas, M., Hignard, C., Babiar, O., Clair-Maczulajtys, D. \& Michel-Salzat, A. 2015: How invasion by Ailanthus altissima transforms soil and litter communities in a temperate forest ecosystem. Biological Invasions 17(6): 18171832. https://doi.org/10.1007/s10530-014-0838-3

Motta, R., Nola, P. \& Berretti, R. 2009: The rise and fall of the black locust (Robinia pseudoacacia L.) in the "Siro Negri" Forest Reserve (Lombardy, Italy): Lessons learned and future uncertainties. Annals of Forest Science 66(4): 410p1-410p10. https://doi.org/10.1051/ forest $/ 2009012$

Mullah, C.J.A., Klanderud, K., Totland, Ø. \& Odee, D. 2014: Community invasibility and invasion by non-native Fraxinus pennsylvanica trees in a degraded tropical forest. Biological Invasions 16(12): 2747-2755. https://doi.org/10.1007/s10530-014-0701-6

Nadal-Sala, D., Sabate, S., Ssnchez-Costa, E., Boumghar, A. \& Gracia, C.A. 2013: Different Responses to Water Availability and Evaporative Demand of Four Co-Occurring Riparian Tree Species in NE Iberian Peninsula: Temporal and Spatial Sap Flow Patterns. In: Steppe K. (ed.): IX International Workshop on Sap Flow. Ghent, Belgium, pp. 215-222.

Nentwig, W., Bacher, S., Kumschick, S., Pyšek, P. \& Vilà, M. 2018: More than "100 worst" alien species in Europe. Biological Invasions 20(6): 1611-1621. https://doi.org/10.1007/s10530-017-1651-6

Notov, A.A., Vinogradova, Yu.K. \& Mayorov, S.R. 2011: On the problem of development and management of regional black books. Russian Journal of Biological Invasions 2: 35-45. https://doi. org/10.1134/S2075111711010061

Novak, N. \& Novak, M. 2018: The differences in the invasiveness of some alien plant species between continental and coastal part of Croatia. Poljoprivreda 24(2): 63-69. https://doi.org/10.18047/ poljo.24.2.9 
Nuñez, M.A., Chiuffo, M.C., Torres, A., Paul, T., Dimarco, R.D., Raal, P., Policelli, N., Moyano, J., García, R.A., van Wilgen, B.W., Pauchard, A. \& Richardson, D.M. 2017: Ecology and management of invasive Pinaceae around the world: progress and challenges. Biological Invasions 19(11): 3099-3120. https://doi.org/10.1007/ s10530-017-1483-4

Orlova-Bienkowskaja, M.J. 2014: Ashes in Europe are in danger: The invasive range of Agrilus planipennis in European Russia is expanding. Biological Invasions 16(7): 1345-1349. https://doi.org/10.1007/ s10530-013-0579-8

Pullin, A.S. \& Stewart, G.B. 2006: Guidelines for Systematic Review in Conservation and Environmental Management. Conservation Biology 20(6): 1647-1656. https://doi.org/10.1111/j.15231739.2006.00485.x

Pyšek, P., Jarošík, V., Pergl, J., Moravcová, L., Chytrý, M. \& Kühn, I. 2014: Temperate trees and shrubs as global invaders: the relationship between invasiveness and native distribution depends on biological traits. Biological Invasions 16(3): 577-589. https://doi.org/10.1007/ s10530-013-0600-2

Pyšek, P., Manceur, A.M., Alba, C., McGregor, K.F., Pergl, J., Štajerová, K., Chytrý, M., Danihelka, J., Kartesz, J., Klimešová, J., Lučanová, M., Moravcová, L., Nishino, M., Sádlo, J., Suda, J., Tichý, L. \& Kühn, I. 2015: Naturalization of central European plants in North America: species traits, habitats, propagule pressure, residence time. Ecology 96: 762-774. https://doi.org/10.1890/14-1005.1

Pyšek, P., Pergl, J., Essl, F., Lenzner, B., Dawson, W., Kreft, H., Weigelt, P., Winter, M., Kartesz, J., Nishino, M., Antonova, L.A., Barcelona, J.F., Cabezas, F.J., Cárdenas, D., Cárdenas-Toro, J., Castańo, N., Chacón, E., Chatelain, C., Dullinger, S., Ebel, A.L., Figueiredo, E., Fuentes, N., Genovesi, P., Groom, Q.J., Henderson, L., Inderjit, Kupriyanov, A., Masciadri, S., Maurel, N., Meerman, J., Morozova, O., Moser, D., Nickrent, D., Nowak, P.M., Pagad, S., Patzelt, A., Pelser, P.B., Seebens, H., Shu, W., Thomas, J., Velayos, M., Weber, E., Wieringa, J.J., Baptiste, M.P. \& van Kleunen, M. 2017: Naturalized alien flora of the world: species diversity, taxonomic and phylogenetic patterns, geographic distribution and global hotspots of plant invasion. Preslia 89: 203-274. https://doi.org/10.23855/ preslia.2017.203

Radtke, A., Ambraß, S., Zerbe, S., Tonon, G., Fontana, V. \& Ammer, C. 2013: Traditional coppice forest management drives the invasion of Ailanthus altissima and Robinia pseudoacacia into deciduous forests. Forest Ecology and Management 291: 308-317. https://doi. org/10.1016/j.foreco.2012.11.022

Rebbeck, J., Hutchinson, T.F. \& Iverson, L.R. 2019: Effects of prescribed fire and stem-injection herbicide on Ailanthus altissima demographics and survival. Forest Ecology and Management 439: 122-131. https://doi.org/10.1016/j.foreco.2019.02.044

Reichard, S.H. \& Hamilton, C.W. 1997: Predicting Invasions of Woody Plants Introduced into North America. Conservation Biology 11: 193-203. https://doi.org/10.1046/j.1523-1739.1997.95473.x

Richardson, D.M. 1998: Forestry Trees as Invasive Aliens. Conservation Biology 12: 18-26. https://doi.org/10.1111/j.15231739.1998.96392.x

Richardson, D.M., Pyšek, P., Rejmánek, M., Barbour, M., Panetta, F.D. \& West, C.J. 2000: Naturalization and invasion of alien plants: concepts and definitions. Diversity and Distributions 6: 93-107. https://doi.org/10.1046/j.1472-4642.2000.00083.x
Richardson, D.M. \& Rejmánek, M. 2011: Trees and shrubs as invasive alien species - a global review. Diversity and Distributions 17: 788-809. https://doi.org/10.1111/j.1472-4642.2011.00782.x

Rumlerová, Z., Vilà, M., Pergl, J., Nentwig, W. \& Pyšek, P. 2016: Scoring environmental and socioeconomic impacts of alien plants invasive in Europe. Biological Invasions 18(12): 3697-3711. https:// doi.org/10.1007/s10530-016-1259-2

Saccone, P., Brun, J.J. \& Michalet, R. 2010a: Challenging growthsurvival trade-off: A key for Acer negundo invasion in European floodplains? Canadian Journal of Forest Research 40(10): 1879-1886. https://doi.org/10.1139/X10-134

Saccone, P., Pagès, J.P., Girel, J., Brun, J.J. \& Michalet, R. 2010b: Acer negundo invasion along a successional gradient: early direct facilitation by native pioneers and late indirect facilitation by conspecifics. New Phytologist 187(3): 831-842. https://doi. org/10.1111/j.1469-8137.2010.03289.x

Saccone, P., Girel, J., Pages, J.P., Brun, J.J. \& Michalet, R. 2013: Ecological resistance to Acer negundo invasion in a European riparian forest: Relative importance of environmental and biotic drivers. Applied Vegetation Science 16(2): 184-192. https://doi.org/10.1111/ j.1654-109X.2012.01227.x

Sakio, H. 2003: Can an exotic plant, Robinia pseudoacacia L., be removed from riparian ecosystems in Japan. Journal of the Japanese Forestry Society 85(4): 355-358.

Säumel, I. \& Kowarik, I. 2013: Propagule morphology and river characteristics shape secondary water dispersal in tree species. Plant Ecology 214(10): 1257-1272. https://doi.org/10.1007/s11258-013-0249-z

Säumel, I. \& Kowarik, I. 2010: Urban rivers as dispersal corridors for primarily wind-dispersed invasive tree species. Landscape and Urban Planning 94(3-4): 244-249. https://doi.org/10.1016/j. landurbplan.2009.10.009

Schmiedel, D. \& Tackenberg, O. 2013: Hydrochory and water induced germination enhance invasion of Fraxinus pennsylvanica. Forest Ecology and Management 304: 437-443. https://doi. org/10.1016/j.foreco.2013.04.027

Seebens, H., Blackburn, T.M., Dyer, E.E., Genovesi, P., Hulme, P.E., Jeschke, J.M., Pagad, S., Pyšek, P., Winter, M., Arianoutsou, M., Bacher, S., Blasius, B., Brundu, G., Capinha, C., Celesti-Grapow, L., Dawson, W., Dullinger, S., Fuentes, N., Jaeger, H., Kartesz, J., Kenis, M., Kreft, H., Kuehn, I., Lenzner, B., Liebhold, A., Mosena, A., Moser, D., Nishino, M., Pearman, D., Pergl, J., Rabitsch, W., RojasSandoval, J., Roques, A., Rorke, S., Rossinelli, S., Roy, H.E., Scalera, R., Schindler, S., Stajerova, K., Tokarska-Guzik, B., van Kleunen, M., Walker, K., Weigelt, P., Yamanaka, T. \& Essl, F. 2017: No saturation in the accumulation of alien species worldwide. Nature Communications 8: 14435. https://doi.org/10.1038/ncomms14435

Seebens, H., Essl, F., Dawson, W., Fuentes, N., Moser, D., Pergl, J., Pyšek, P., Kleunen, M., Weber, E., Winter, M. \& Blasius, B. 2015: Global trade will accelerate plant invasions in emerging economies under climate change. Global Change Biology 21: 4128-4140. https:// doi.org/10.1111/gcb.13021

Shackleton, R.T., Le Maitre, D.C., van Wilgen, B.W. \& Richardson, D.M. 2017: Towards a national strategy to optimise the management of a widespread invasive tree (Prosopis species; mesquite) in South Africa. Ecosystem Services 27: 242-252. https://doi.org/10.1016/j. ecoser.2016.11.022 
Simberloff, D., Martin, J.L., Genovesi, P., Maris, V., Wardle,D.A., Aronson, J., Courchamp, F., Galil, B., García-Berthou, E., Pascal,M., Pyšek, P., Sousa, R., Tabacchi, E. \& Vilà, M. 2013: Impacts of biological invasions: what's what and the way forward. Trends in Ecology \& Evolution 28: 58-66. https://doi.org/10.1016/j.tree.2012.07.013

Sitzia, T., Campagnaro, T., Dainese, M. \& Cierjacks, A. 2012: Plant species diversity in alien black locust stands: A paired comparison with native stands across a north-Mediterranean range expansion. Forest Ecology and Management 285: 85-91. https://doi.org/10.1016/j. foreco.2012.08.016

Sitzia, T., Campagnaro, T., Kotze, D.J., Nardi, S. \& Ertani, A. 2018: The invasion of abandoned fields by a major alien tree filters understory plant traits in novel forest ecosystems. Scientific Reports 8(1): 8410. https://doi.org/10.1038/s41598-018-26493-3

Slabejová, D., Bacigál, T., Hegedüšová, K., Májeková, J., Medvecká, J., Mikulová, K., Šibíková, M., Śkodová, I., Zaliberová, M. \& Jarolímek, I. 2019: Comparison of the understory vegetation of native forests and adjacent Robinia pseudoacacia plantations in the Carpathian-Pannonian region. Forest Ecology and Management 439: 28-40. https://doi. org/10.1016/j.foreco.2019.02.039

Sladonja, B., Sušek, M. \& Guillermic, J. 2015: Review on Invasive Tree of Heaven (Ailanthus altissima (Mill.) Swingle) Conflicting Values: Assessment of Its Ecosystem Services and Potential Biological Threat. Environmental Management 56(4): 1009-1034. https://doi. org/10.1007/s00267-015-0546-5

Slodowicz, D., Kikodze, D., Khutsishvili, M., Kalatozishvili, L. \& Müller-Schärer, H. 2018: Monitoring of invasive alien plants in protected areas of Georgia. Bulletin of the Georgian National Academy of Sciences 12(2): 111-116.

Staska, B., Essl, F. \& Samimi, C. 2014: Density and age of invasive Robinia pseudoacacia modulate its impact on floodplain forests. Basic and Applied Ecology 15(6): 551-558. https://doi.org/10.1016/j. baae.2014.07.010

Straigyté, L., Cekstere, G., Laivins, M. \& Marozas, V. 2015: The spread, intensity and invasiveness of the Acer negundo in Riga and Kaunas. Dendrobiology 74: 157-168. https://doi.org/10.12657/ denbio.074.016

Stricker, K.B., Hagan, D. \& Flory, S.L. 2015: Improving methods to evaluate the community and ecosystem impacts of plant invasions: Synthesis and recommendations. AoB Plants 7: plv028. https://doi. org/10.1093/aobpla/plv028

Tabacchi, E. \& Planty-Tabacchi, A.M. 2003: Recent changes in Riparian vegetation: Possible consequences on dead wood processing along rivers. River Research and Applications 19(3): 251-263. https:// doi.org/10.1016/10.1002/rra.755

Terwei, A., Zerbe, S., Zeileis, A., Annighöfer, P., Kawaletz, H., Mölder, I. \& Ammer, C. 2013: Which are the factors controlling tree seedling establishment in North Italian floodplain forests invaded by non-native tree species? Forest Ecology and Management 304: 192-203. https:// doi.org/10.1016/j.foreco.2013.05.003

Valantinaite, A., Straigyte, L. \& Jurksiene, G. 2011: Comparative Analysis of Invasion Intensity of Box Elder (Acer negundo L.) and Sosnowskyi Hogweed (Heracleum sosnowskyi Manden.). In: $5^{\text {th }}$ International Scientific Conference "Rural Development in Global Changes", vol. 5(2), pp. 161-166.

van Kleunen, M., Dawson, W., Essl, F., Pergl, J., Winter, M., Weber, E., Kreft, H., Weigelt, P., Kartesz, J., Nishino, M., Antonova, L.A.,
Barcelona, J.F., Cabezas, F.J., Cárdenas, D., Cárdenas-Toro, J., Castańo, N., Chacón, E., Chatelain, C., Ebel, A.L., Figueiredo, E., Fuentes, N., Groom, Q.J., Henderson, L., Inderjit, Kupriyanov, A., Masciadri, S., Meerman, J., Morozova, O., Moser, D., Nickrent, D.L., Patzelt, A., Pelser, P.B., Baptiste, M.P., Poopath, M., Schulze, M., Seebens, H., Shu, W.S., Thomas, J., Velayos, M., Wieringa, J.J. \& Pyšek, P. 2015: Global exchange and accumulation of non-native plants. Nature 525: 100-103. https://doi.org/10.1038/nature14910

Veselkin, D.V., Kiseleva, O.A., Ekshibarov, E.D., Rafikova, O.S. \& Korzhinevskaya, A.A. 2018: Abundance and Diversity of Seedlings of the Soil Seed Bank in the Thickets of the Invasive Species Acer negundo L. Russian Journal of Biological Invasions 9(2): 108-113. https://doi. org/10.1134/S2075111718020133

Vilà, M., Basnou, C., Pyšek, P., Josefsson, M., Genovesi, P., Gollasch,S., Nentwig, W., Olenin, S., Roques, A., Roy, D. \& Hulme, P.E. 2010: How well do we understand the impacts of alien species on ecosystem services? A pan-European, cross-taxa assessment. Frontiers in Ecology and the Environment 8: 135-144. https://doi. org/10.1890/080083

Vinogradova, Yu.K. \& Kuprianov, A.N. (Eds.). 2016: Black Data Book of the Siberian flora. Russian Academy of Sciences, Novosibirsk. 440 pp. [in Russian]

Vinogradova, Yu.K., Mayorov, S.R. \& Khorun, L.V. 2010: Black Data Book of flora of Central Russia: alien plant species in ecosystems of Central Russia. GEOS, Moscow. 502 pp. [in Russian]

Vinogradova, Yu.K., Mayorov, S.R. \& Notov, A.A. 2011: Black Data Book of flora of Tver Region: alien plant species in ecosystems of the Tver Region. KMK, Moscow. 296 pp. [in Russian]

Vinogradova, Y., Pergl, J., Essl, F., Hejda, M., van Kleunen, M. \& Pyšek, P. 2018: Invasive alien plants of Russia: insights from regional inventories. Biological Invasions 20(8): 1931-1943. https://doi. org/10.1007/s10530-018-1686-3

Vítková, M., Müllerová, J., Sádlo, J., Pergl, J. \& Pyšek, P. 2017: Black locust (Robinia pseudoacacia) beloved and despised: A story of an invasive tree in Central Europe. Forest Ecology and Management 384: 287-302. https://doi.org/10.1016/j.foreco.2016.10.057

Wagner, V., Chytrý, M., Jimenez-Alfaro, B., Pergl, J., Hennekens, S., Biurrun, I., Knollová, I., Berg, C., Vassilev, K., Rodwell, J.S., Škvorc, Z., Jandt, U., Ewald, J., Jansen, F., Tsiripidis, I., Botta-Dukat, Z., Casella, L., Attorre, F., Rašomavičius, V., Ćušterevska, R., Schaminée, J.H.J., Brunet, J., Lenoir, J., Svenning, J.-C., Kącki, Z., PetrasovaSibikova, M., Silc, U., Garcia-Mijangos, I., Antonio Campos, J., Fernandez-Gonzalez, F., Wohlgemuth, T., Onyshchenko, V. \& Pyšek, P. 2017: Alien plant invasions in European woodlands. Diversity and Distributions 23(9): 969-981. https://doi.org/10.1111/ddi.12592

Wei, J., Li, Z., Jiao, L., Chen, W., Wu, X., Wang, X. \& Wang, S. 2018: Climate effect on the radial growth of introduced and native tree species in the Yangjuangou catchment of the Loess Plateau. Acta Ecologica Sinica 38(22): 8040-8050. https://doi.org/10.5846/ stxb201801100079

Westgate, M.J. \& Lindenmayer, D.B. 2017: The difficulties of systematic reviews. Conservation Biology 31(5): 1002-1007. https:// doi.org/10.1111/cobi.12890

Xu, H.G., Qiang, S., Genovesi, P., Ding, H., Wu, J., Meng, L., Han, Z.M., Miao, J.L., Hu, B.S., Guo, J.Y., Sun, H.Y., Huang, C., Lei, J.C., Le, Z.F., Zhang, X.P., He, S.P., Wu, Y., Zheng, Z., Chen, L., Jarošík, V. \& Pyšek, P. 2012: An inventory of invasive alien species in China. Neobiota 15: 1-26. https://doi.org/10.3897/neobiota.15.3575 
Yan, X.E., Zhenyu, L., Gregg, W.P. \& Dianmo, L. 2004: Invasive species in China - an overview. Biodiversity and Conservation 10(8): 1317-1341. https://doi.org/10.1023/A:1016695609745

Yazlık, A., Pergl, J. \& Pyšek, P. 2018: Impact of alien plants in Turkey assessed by the Generic Impact Scoring System. NeoBiota 39: 31-51. https://doi.org/10.3897/neobiota.39.23598

Yu, F., Akin-Fajiye, M., Thapa Magar, K., Ren, J., Gurevitch, J. \& Rejmánek, M. 2016: A global systematic review of ecological field studies on two major invasive plant species, Ageratina adenophora and Chromolaena odorata. Diversity and Distributions 22(11): 1174-1185. https://doi.org/10.1111/ddi.12481

\section{Appendix}

The search strings and criteria used to summarize the invasive biology literature on Acer negundo, Fraxinus pennsylvanica, Ailanthus altissima, Robinia pseudoacacia in Web of Science Core Collection.

\section{Search strings}

\section{Ailanthus altissima}

Topic: [(invasi* OR invader OR alien OR exotic OR ruderal OR weed OR non-native OR introduced OR naturaliz*) AND ("Ailanthus altissima" OR "Tree of heaven" OR "tree-of-heaven" OR "Ailanthus cacodendron" OR "Ailanthus giraldii" OR "Ailanthus glandulosa" OR "Ailanthus peregrina" OR "Ailanthus sutchuensis" OR "Ailanthus vilmoriniana" OR "Albonia peregrina" OR "Pongelion glandulosum" OR "Rhus cacodendron" OR "Toxicodendron altissimum" OR "China sumac" OR "copal tree" OR "varnish tree")].

Acer negundo

Topic: [(invasi* OR invader OR alien OR exotic OR ruderal OR weed OR non-native OR introduced OR naturaliz*) AND ("Acer negundo" OR "Ashleaf maple" OR "American maple")];

Robinia pseudoacacia

Topic: [(invasi* OR invader OR alien OR exotic OR ruderal OR weed OR non-native OR introduced OR naturaliz*) AND ("Robinia pseudoacacia" OR "Robinia pringlei" OR "robinia akacjowa" OR "yellow locust" OR "robiner faux-acacia" OR "black locust" OR "Post locust" OR "Chinese scolartree")].

Fraxinus pennsylvanica

Topic: [(invasi* OR invader OR alien OR exotic OR ruderal OR weed OR non-native OR introduced OR naturaliz*) AND ("Fraxinus pennsylvanica" OR "Green Ash" OR "downy ash" OR "Fraxinus lanceolata" OR "Fraxinus pubescens" OR "Fraxinus viridis" OR "red ash" OR "swamp ash" OR "water ash")].
Zajpler, M., Tyborski, J., Dyderski, M.K. \& Jagopziński, A.M. 2018 : Dendroclimatological analysis of radial increments of invasive Acer negundo L. and Fraxinus pennsylvanica Marshall from the Warta river valley. Sylwan 162(7): 547-554.

Zimmermann, T.G., Andrade, A.C.S. \& Richardson, D.M. 2017: Abiotic barriers limit tree invasion but do not hamper native shrub recruitment in invaded stands. Biological Invasions 19(1): 109-129. https://doi.org/10.1007/s10530-016-1267-2

\section{Research areas excluded from analysis for each species}

\section{Ailanthis altissima}

"acoustics OR "pharmacology pharmacy" OR "biochemistry molecular biology" OR "geology" OR "history philosophy of science" OR "physiology" OR "biotechnology applied microbiology" OR "imaging science photographic technology" OR "chemistry" OR "integrative complementary medicine" OR "energy fuels" OR "life sciences biomedicine other topics" OR "engineering" OR "science technology other topics" OR "social sciences other topics" OR "meteorology atmospheric sciences" OR "microbiology or water resources" OR "food science technology" OR "mycology" OR "oncology".

Acer negundo

"geology" OR "life sciences biomedicine other topics" OR "science technology other topics" OR "mycology" OR "water resources" OR "fisheries" OR "paleontology".

\section{Robinia pseudoacacia}

"nutrition dietetics" OR "biochemistry molecular biology" OR "genetics heredity" OR "parasitology" OR "biophysics" OR "geology" OR "physics" OR "biotechnology applied microbiology" OR "imaging science photographic technology" OR "cell biology" OR "life sciences biomedicine other topics" OR "computer science" OR "science technology other topics" OR "engineering" OR "materials science" OR "meteorology atmospheric sciences" OR "veterinary sciences" OR "microbiology" OR "water resources" OR "mycology" OR "food science technology".

\section{Fraxinus excelsior}

"meteorology atmospheric sciences" OR "biochemistry molecular biology" OR "food science technology" OR "microbiology" OR "physics" OR "biotechnology applied microbiology" OR "genetics heredity" OR "chemistry" OR "instruments instrumentation" OR "science technology other topics" OR "dermatology" OR "life sciences biomedicine other topics" OR "veterinary sciences" OR "engineering" OR "materials science". 
Bibliography of included papers on Fraxinus pennsylvanica listed in alphabetical order of records (asterisk “*” indicate publications indexed in both databases)

\section{Bibliography of included papers from WoS CC}

1 *Batanjski, V., Kabaš, E., Kuzmanović, N., Vukojičić S., Lakušić, D. \& Jovanović, S. 2015: New invasive forest communities in the riparian fragile habitats: The case study from Ramsar site Carska bara (Vojvodina, Serbia). Sumarski List 139(3-4): 155-169.

$2{ }^{*}$ Chindyaeva, L.N., Belanova, A.P. \& Kiseleva, T.I. 2018: Patterns of Natural Regeneration of Alien Species of Woody Plants in Novosibirsk. Russian Journal of Biological Invasions 9(3): 273-285. https://doi. org/10.1134/S2075111718030025

3 *Kremer, D. \& Čavlović, J. 2005: Distribution of introduced North American ash species and their role in lowland forest management in Croatia. Journal of Forestry 103(6): 309-313.

4 *Kremer, D., Čavlović, J. \& Bozic, M. 2006: Growth characteristics of introduced green ash (Fraxinus pennsylvanica Marshall) and narrow-leaved ash (F. angustifolia L.) in lowland forest region in Croatia. New Forests 31(2): 211-224. https://doi.org/10.1007/ s11056-005-5176-y

$5{ }^{*}$ Mullah, C.J.A., Klanderud, K., Totland, Ø. \& Odee, D. 2014: Community invasibility and invasion by non-native Fraxinus pennsylvanica trees in a degraded tropical forest. Biological Invasions 16(12): 27472755. https://doi.org/10.1007/s10530-014-0701-6

6 *Schmiedel, D., Huth, F. \& Wagner, S. 2013: Using data from seed-dispersal modelling to manage invasive tree species: The example of Fraxinus pennsylvanica Marshall in Europe. Environmental Management 52(4): 851-860. https://doi.org/10.1007/s00267-013 -0135-4

$7{ }^{*}$ Schmiedel, D. \& Tackenberg, O. 2013: Hydrochory and water induced germination enhance invasion of Fraxinus pennsylvanica. Forest Ecology and Management 304: 437-443. https://doi.org/10.1016/j. foreco.2013.04.027

8 *Zajpler, M., Tyborski, J., Dyderski, M.K. \& Jagopziński, A.M. 2018: Dendroclimatological analysis of radial increments of invasive Acer negundo L. and Fraxinus pennsylvanica Marshall from the Warta river valley. Sylwan 162(7): 547-554.

\section{Bibliography of included papers from Scopus}

1. *Batanjski, V., Kabaš, E., Kuzmanović, N., Vukojičić S., Lakušić, D. \& Jovanović, S. 2015: New invasive forest communities in the riparian fragile habitats: The case study from Ramsar site Carska bara (Vojvodina, Serbia). Sumarski List 139(3-4): 155-169.
2. ${ }^{*}$ Chindyaeva, L.N., Belanova, A.P. \& Kiseleva, T.I. 2018: Patterns of Natural Regeneration of Alien Species of Woody Plants in Novosibirsk. Russian Journal of Biological Invasions 9(3): 273-285. https://doi. org/10.1134/S2075111718030025

3. Drescher, A. \& Prots, B. 2016: Fraxinus pennsylvanica - an invasive tree species in Middle Europe: case studies from the Danube basin. Contributii Botanice 51: 55-69.

4. Glišić, M., Lakušić, O., Šinžar-Sekulić, J. \& Jovanović, S. 2014: GIS analysis of spatial distribution of invasive tree species in the protected natural area of Mt. Avala (Serbia). Botanica Serbica 38(1): 131-138.

5. Hale, B.W. \& Adams, M.S. 2011: Historical change and management of the floodplain forests of the Middle Elbe River. In: H.S. Elliot, L.E. Martin (eds.): River Ecosystems: Dynamics, Management and Conservation, Nova Science Publishers, Inc., New York, pp. 149-178.

6. Idžojtić, M. \& Zebec, M. 2006: Distribution of the tree of heaven (Ailanthus altissima (Mill.) Swingle) and spreading of invasive woody alien species in Croatia. Glasnik za Sumske Pokuse 5(Special Issue): 315-323.

7. *Kremer, D. \& Čavlović, J. 2005: Distribution of introduced North American ash species and their role in lowland forest management in Croatia. Journal of Forestry 103(6): 309-313.

8. *Kremer, D., Čavlović, J. \& Bozic, M. 2006: Growth characteristics of introduced green ash (Fraxinus pennsylvanica Marshall) and narrow-leaved ash (F.angustifolia L.) in lowland forest region in Croatia. New Forests 31(2): 211-224. https://doi.org/10.1007/ s11056-005-5176-y

9. Kremer, D., Pernar R. \& Ančić, M. 2006: Distribution of North American ash species in the Drava River basin and Danube basin (Croatia). Acta Botanica Croatica 65(1): 57-66.

10. Möllerová, J. 2005: Notes on invasive and expansive trees and shrubs. Journal of Forest Science 51: 19-23.

11. *Mullah, C.J.A., Klanderud, K., Totland, Ø. \& Odee, D. 2014: Community invasibility and invasion by non-native Fraxinus pennsylvanica trees in a degraded tropical forest. Biological Invasions 16(12): 27472755. https://doi.org/10.1007/s10530-014-0701-6

12. *Schmiedel, D., Huth, F. \& Wagner, S. 2013: Using data from seed-dispersal modelling to manage invasive tree species: The example of Fraxinus pennsylvanica Marshall in Europe. Environmental Management 52(4): 851-860. https://doi.org/10.1007/ s00267-013-0135-4 
13. *Schmiedel, D. \& Tackenberg, O. 2013: Hydrochory and water induced germination enhance invasion of Fraxinus pennsylvanica. Forest Ecology and Management 304: 437-443. https://doi.org/10.1016/j. foreco.2013.04.027

14. *Zajpler, M., Tyborski, J., Dyderski, M.K. \& Jagopziński, A.M. 2018: Dendroclimatological analysis of radial increments of invasive Acer negundo L. and Fraxinus pennsylvanica Marshall from the Warta river valley. Sylwan 162(7): 547-554.

\section{Bibliography of included papers on Acer negundo} listed in alphabetical order of records (asterisk "*" indicate publications indexed in both databases)

\section{Bibliography of included papers from WoS CC}

1. *Akatov, V.V., Akatova, T.V. \& Shadzhe, A.E. 2012: Species richness of tree and shrub layers in riparian forests of the Western Caucasus dominated by alien species. Russian Journal of Ecology 43(4): 294-301. https://doi.org/10.1134/S1067413612040030

2. *Batanjski, V., Kabaš, E., Kuzmanović, N., Vukojičić S., Lakušić, D. \& Jovanović, S. 2015: New invasive forest communities in the riparian fragile habitats: The case study from Ramsar site Carska bara (Vojvodina, Serbia). Sumarski List 139(3-4): 155-169.

3. *Bennett, B.A., Catling, P.M., Cody, W.J. \& Argus, G.W. 2010: New records of vascular plants in the Yukon Territory VIII. Canadian Field-Naturalist 124(1): 1-27.

4. *Berg, C., Drescher, A. \& Essl, F. 2017: Using relevébased metrics to explain invasion patterns of alien trees in temperate forests. Tuexenia 37(1): 127-142. https://doi.org/10.14471/2017.37.012

5. *Berg, C., Drescher, A., Wagner, V. \& Essl, F. 2016: Temporal trends in the invasions of Austrian woodlands by alien trees. Preslia 88(2): 185-200.

6. *Bottollier-Curtet, M., Charcosset, J.Y., Poly, F., Planty-Tabacchi, A.M. \& Tabacchi, E. 2012: Light interception principally drives the understory response to boxelder invasion in riparian forests. Biological Invasions 14(7): 1445-1458. https://doi. org/10.1007/s10530-011-0170-0

7. ${ }^{*}$ Chindyaeva, L.N., Belanova, A.P. \& Kiseleva, T.I. 2018: Patterns of Natural Regeneration of Alien Species of Woody Plants in Novosibirsk. Russian Journal of Biological Invasions 9(3): 273-285. https://doi. org/10.1134/S2075111718030025

8. *Dragotă, C.-S., Grigorescu, I., Dumitraşcu, M., Năstase, M. \& Herlo, G. 2015: Climate variables for the assessment of the invasive terrestrial plant species in the Mureș floodplain natural Park. Romania. In:
International multidisciplinary scientifc geoconference "SGEM. Surveying Geology and Mining Ecology Management”, vol. 2(5), pp. 103-110.

9. *Dyakov, N. \& Zhelev, P. 2013: Alien species invasion and diversity of riparian forest according to environmental gradients and disturbance regime. Applied Ecology and Environmental Research 11(2): 249272. https://doi.org/10.15666/aeer/1102_249272

10. *Dyderski, M.K., Gdula, A.K. \& Jagodziński, A.M. 2015: "The rich get richer" concept in riparian woody species - A case study of the Warta River Valley (Poznań, Poland). Urban Forestry \& Urban Greening 14(1): 107-114 https://doi.org/10.1016/j. ufug.2014.12.003

11. *Erfmeier, A., Böhnke, M. \& Bruelheide, H. 2011: Secondary invasion of Acer negundo: The role of phenotypic responses versus local adaptation. Biological Invasions 13(7): 1599-1614. https://doi. org/10.1007/s10530-010-9917-2

12. *Fagúndez, J. 2007: New data of some exotic vascular plant species from Galicia (northwestern Iberian Peninsula). Lazaroa 28: 111-114.

13. *Golovanov, Y.M., Abramova, L.M. \& Petrov, S.S. 2018: Invasive species in phytocenosis of Sterlitamak town (Republic of Bashkortostan, Russia). IOP Conference Series: Earth and Environmental Science 107(1): 012085. https://doi.org/10.1088/1755$1315 / 107 / 1 / 012085$

14. Grigorescu, I., Dumitrascu, M., Kucsicsa, G., Doroftei, M., Dragota, C.S. \& Nastase, M. 2014: Assessing invasive terrestrial plant species in the Mures Floodplain Natural Park, Romania. In: $14^{\text {th }}$ nternational Multidisciplinary Scientific Geoconference (SGEM) "Geoconference on Ecology, Economics, Education and Legislation", vol. 1, Albena, pp. 51-58.

15. *Höfle, R., Dullinger, S. \& Essl, F. 2014: Different factors affect the local distribution, persistence and spread of alien tree species in floodplain forests. Basic and Applied Ecology 15(5): 426-434. https://doi. org/10.1016/j.baae.2014.07.007

16. *Horvat, G. \& Franjić, J. 2016: Invasive plants of Kalnik forests. Sumarski List 140(1-2): 53-64.

17. *Kowarik, I., Von Der Lippe, M. \& Cierjacks, A. 2013: Prevalence of alien versus native species of woody plants in Berlin differs between habitats and at different scales. Preslia 85(2): 113-132.

18. *Krevš, A., Kučinskiené, A., Mačkinaitè, R. \& Manusadžianas, L. 2017: Microbial colonization and decomposition of invasive and native leaf litter in the littoral zone of lakes of different trophic state. Limnologica 67: 54-63. https://doi.org/10.1016/j. limno.2017.08.002 
19. *Lamarque, L.J., Delzon, S., Sloan, M.H. \& Lortie, C.J. 2012: Biogeographical contrasts to assess local and regional patterns of invasion: A case study with two reciprocally introduced exotic maple trees. Ecography 35(9): 803-810. https://doi.org/10.1111/ j.1600-0587.2011.07300.x

20. *Marozas, V., Cekstere, G., Laivins, M. \& Straigyte, L. 2015: Comparison of neophyte communities of Robinia pseudoacacia L. and Acer negundo L. in the eastern Baltic Sea region cities of Riga and Kaunas. Urban Forestry and Urban Greening 14(4): 826834. https://doi.org/10.1016/j.ufug.2015.08.003

21. *Porté, A.J., Lamarque, L.J., Lortie, C.J., Michalet, R. \& Delzon, S. 2011: Invasive Acer negundo outperforms native species in non-limiting resource environments due to its higher phenotypic plasticity. BMC Ecology 11:28. https://doi.org/10.1186/14726785-11-28

22. *Saccone, P., Brun, J.J. \& Michalet, R. 2010: Challenging growth-survival trade-off: A key for Acer negundo invasion in European floodplains? Canadian Journal of Forest Research 40(10): 1879-1886. https://doi.org/10.1139/X10-134

23. *Saccone, P., Pagès, J.P., Girel, J., Brun, J.J. \& Michalet, R. 2010: Acer negundo invasion along a successional gradient: early direct facilitation by native pioneers and late indirect facilitation by conspecifics. New Phytologist 187(3): 831-842. https://doi. org/10.1111/j.1469-8137.2010.03289.x

24. *Saccone, P., Girel, J., Pages, J.P., Brun, J.J. \& Michalet, R. 2013: Ecological resistance to Acer negundo invasion in a European riparian forest: Relative importance of environmental and biotic drivers. Applied Vegetation Science 16(2): 184-192. https://doi. org/10.1111/j.1654-109X.2012.01227.x

25. *Säumel, I. \& Kowarik, I. 2010: Urban rivers as dispersal corridors for primarily wind-dispersed invasive tree species. Landscape and Urban Planning 94(3-4): 244-249. https://doi.org/10.1016/j.landurbplan.2009.10.009

26. *Säumel, I. \& Kowarik, I. 2013: Propagule morphology and river characteristics shape secondary water dispersal in tree species. Plant Ecology 214(10): 1257-1272. https://doi.org/10.1007/s11258-0130249-z

27. *Spáčilová, B. \& Stredová, H. 2014: Disputed recreational and ecological stabilization functions of celected windbreaks. In: D. Pernicova, J. Fialova (eds.): Public Recreation and Landscape Protection - With Man Hand in Hand? Mendel University in Brno, Brno, pp. 85-91.

28. *Straigytè, L., Cekstere, G., Laivins, M. \& Marozas,
V. 2015: The spread, intensity and invasiveness of the Acernegundo in Riga and Kaunas. Dendrobiology 74: 157-168. https://doi.org/10.12657/denbio.074.016

29. *Tabacchi, E. \& Planty-Tabacchi, A.M. 2003: Recent changes in Riparian vegetation: Possible consequences on dead wood processing along rivers. River Research and Applications 19(3): 251-263. https:// doi.org/10.1016/10.1002/rra.755

30. *Tafra, D., Pandža, M. \& Milović, M. 2012: Woody plants of the Omis. Sumarski List 136(11-12): 605-617.

31. Valantinaite, A., Straigyte, L. \& Jurksiene, G. 2011: Comparative Analysis of Invasion Intensity of Box Elder (Acer negundo L.) and Sosnowskyi Hogweed (Heracleum sosnowskyi Manden.). In: $5^{\text {th }}$ International Scientific Conference "Rural Development in Global Changes", vol. 5(2), pp. 161-166.

32. *Veselkin, D.V., P'yankov, S.V., Safonov, M.A. \& Betekhtina, A.A. 2017: The structure of absorbing roots in invasive and native maple species. Russian Journal of Ecology 48(4): 303-310. https://doi. org/10.1134/S1067413617040166

33. *Veselkin, D.V., Kiseleva, O.A., Ekshibarov, E.D., Rafikova, O.S. \& Korzhinevskaya, A.A. 2018: Abundance and Diversity of Seedlings of the Soil Seed Bank in the Thickets of the Invasive Species Acer negundo L. Russian Journal of Biological Invasions 9(2): 108113. https://doi.org/10.1134/S2075111718020133

34. *Zajpler, M., Tyborski, J., Dyderski, M.K. \& Jagopziński, A.M. 2018: Dendroclimatological analysis of radial increments of invasive Acer negundo L. and Fraxinus pennsylvanica Marshall from the Warta river valley. Sylwan 162(7): 547-554.

35. *Zelnik, I., Haler, M. \& Gaberscik, A. 2015: Vulnerability of a riparian zone towards invasion by alien plants depends on its structure. Biologia 70(7): 869878. https://doi.org/10.1515/biolog-2015-0110

\section{Bibliography of included papers from Scopus}

1. *Akatov, V.V., Akatova, T.V. \& Shadzhe, A.E. 2012: Species richness of tree and shrub layers in riparian forests of the Western Caucasus dominated by alien species. Russian Journal of Ecology 43(4): 294-301. https://doi.org/10.1134/S1067413612040030

2. *Batanjski, V., Kabaš, E., Kuzmanović, N., Vukojičić S., Lakušić, D. \& Jovanović, S. 2015: New invasive forest communities in the riparian fragile habitats: The case study from Ramsar site Carska bara (Vojvodina, Serbia). Sumarski List 139(3-4): 155-169.

3. *Bennett, B.A., Catling, P.M., Cody, W.J. \& Argus, G.W. 2010: New records of vascular plants in 
the Yukon Territory VIII. Canadian Field-Naturalist 124(1): 1-27.

4. *Berg, C., Drescher, A. \& Essl, F. 2017: Using relevébased metrics to explain invasion patterns of alien trees in temperate forests. Tuexenia 37(1): 127-142. https://doi.org/10.14471/2017.37.012

5. *Berg, C., Drescher, A., Wagner, V. \& Essl, F. 2016: Temporal trends in the invasions of Austrian woodlands by alien trees. Preslia 88(2): 185-200.

6. *Bottollier-Curtet, M., Charcosset, J.Y., Poly, F., Planty-Tabacchi, A.M. \& Tabacchi, E. 2012: Light interception principally drives the understory response to boxelder invasion in riparian forests. Biological Invasions 14(7): 1445-1458. https://doi. org/10.1007/s10530-011-0170-0

7. *Chindyaeva, L.N., Belanova, A.P. \& Kiseleva, T.I. 2018: Patterns of Natural Regeneration of Alien Species of Woody Plants in Novosibirsk. Russian Journal of Biological Invasions 9(3): 273-285. https://doi. org/10.1134/S2075111718030025

8. *Dragotă, C.-S., Grigorescu, I., Dumitraşcu, M., Năstase, M. \& Herlo, G. 2015: Climate variables for the assessment of the invasive terrestrial plant species in the Mureş floodplain natural Park. Romania. In: International multidisciplinary scientifc geoconference "SGEM. Surveying Geology and Mining Ecology Management", vol. 2(5), pp. 103-110.

9. *Dyakov, N. \& Zhelev, P. 2013: Alien species invasion and diversity of riparian forest according to environmental gradients and disturbance regime. Applied Ecology and Environmental Research 11(2): 249272. https://doi.org/10.15666/aeer/1102_249272

10. *Dyderski, M.K., Gdula, A.K. \& Jagodziński, A.M. 2015: "The rich get richer" concept in riparian woody species - A case study of the Warta River Valley (Poznań, Poland). Urban Forestry \& Urban Greening 14(1): 107-114 https://doi.org/10.1016/j. ufug.2014.12.003

11. Ebone, A., Cristaldi, L., Buzio, S. \& Chiarabaglio, P.M. 2015: Invasive alien species management in forest and protected areas. Italian Botanist 47(2): 370-371.

12. *Erfmeier, A., Böhnke, M. \& Bruelheide, H. 2011 : Secondary invasion of Acer negundo: The role of phenotypic responses versus local adaptation. Biological Invasions 13(7): 1599-1614. https://doi. org/10.1007/s10530-010-9917-2

13. *Fagúndez, J. 2007: New data of some exotic vascular plant species from Galicia (northwestern Iberian Peninsula). Lazaroa 28: 111-114.

14. Glišić, M., Lakušić, O., Šinžar-Sekulić, J. \& Jovanović, S. 2014: GIS analysis of spatial distribution of invasive tree species in the protected natural area of Mt. Avala (Serbia). Botanica Serbica 38(1): 131-138.

15. *Golovanov, Y.M., Abramova, L.M. \& Petrov, S.S. 2018: Invasive species in phytocenosis of Sterlitamak town (Republic of Bashkortostan, Russia). IOP Conference Series: Earth and Environmental Science 107(1): 012085. https://doi.org/10.1088/17551315/107/1/012085

16. *Hö̈le, R., Dullinger, S. \& Essl, F. 2014: Different factors affect the local distribution, persistence and spread of alien tree species in floodplain forests. Basic and Applied Ecology 15(5): 426-434. https://doi. org/10.1016/j.baae.2014.07.007

17. *Horvat, G. \& Franjić, J. 2016: Invasive plants of Kalnik forests. Sumarski List 140(1-2): 53-64.

18. Idžojtić, M. \& Zebec, M. 2006: Distribution of the tree of heaven (Ailanthus altissima (Mill.) Swingle) and spreading of invasive woody alien species in Croatia. Glasnik za Sumske Pokuse 5(Special Issue): 315-323.

19. Kolyada, N.A. \& Kolyada, A.S. 2017: Occurrence of potentially invasive species box elder (Acer negundo L.) in the south of the Russian Far East. Russian Journal of Biological Invasions 8(1): 41-44. https:// doi.org/10.1134/S2075111717010052

20. Kostina, M.V., Minkova, N.O. \& Yasinskaya, O.I. 2014: Some biological features of Acer negundo L. in green plantations of Moscow. Russian Journal of Biological Invasions 5(1): 21-28. https://doi. org/10.1134/S2075111714010068

21. Kostina, M.V., Yasinskaya, O.I., Barabanshchikova, N.S. \& Orlyuk, F.A. 2016: Toward a issue of box elder invasion into the forests around Moscow. Russian Journal of Biological Invasions 7(1): 47-51. https:// doi.org/10.1134/S2075111716010069

22. *Kowarik, I., Von Der Lippe, M. \& Cierjacks, A. 2013: Prevalence of alien versus native species of woody plants in Berlin differs between habitats and at different scales. Preslia 85(2): 113-132.

23. *Krevš, A., Kučinskienė, A., Mačkinaitė, R. \& Manusadžianas, L. 2017: Microbial colonization and decomposition of invasive and native leaf litter in the littoral zone of lakes of different trophic state. Limnologica 67: 54-63. https://doi.org/10.1016/j. limno.2017.08.002

24. *Lamarque, L.J., Delzon, S., Sloan, M.H. \& Lortie, C.J. 2012: Biogeographical contrasts to assess local and regional patterns of invasion: A case study with two reciprocally introduced exotic maple trees. Ecography 35(9): 803-810. https://doi.org/10.1111/ j.1600-0587.2011.07300.x 
25. *Marozas, V., Cekstere, G., Laivins, M. \& Straigyte, L. 2015: Comparison of neophyte communities of Robinia pseudoacacia L. and Acer negundo L. in the eastern Baltic Sea region cities of Riga and Kaunas. Urban Forestry and Urban Greening 14(4): 826834. https://doi.org/10.1016/j.ufug.2015.08.003

26. Merceron, N.R., Lamarque, L.J., Delzon, S. \& Porté, A.J. 2016: Killing it softly: Girdling as an efficient eco-friendly method to locally remove invasive Acer negundo. Ecological Restoration 34(4): 297-305. https://doi.org/10.3368/er.34.4.297

27. Möllerová, J. 2005: Notes on invasive and expansive trees and shrubs. Journal of Forest Science 51: $19-23$.

28. Otmakhov, Y.S., Chernikova, T.S. \& Tretyakov, B.A. 2018. Anthropogenic transformation of vegetation in urban pine forests. Vestnik Tomskogo Gosudarstvennogo Universiteta, Biologiya, 41: 75-95. https:// doi.org/10.17223/19988591/41/5

29. Pandža, M. \& Tafra, D. 2008: Addition to the neophytic flora of the Cetina River region. Natura Croatica 17(2): 91-112.

30. *Porté, A.J., Lamarque, L.J., Lortie, C.J., Michalet, R. \& Delzon, S. 2011: Invasive Acer negundo outperforms native species in non-limiting resource environments due to its higher phenotypic plasticity. BMC Ecology 11:28. https://doi.org/10.1186/14726785-11-28

31. Rutkovska, S., Pučkina, I. \& Frolova, O. 2017: Inventory of the most invasive alien plant species of Latvia in the "Daugavas Loki" Nature Park. In: $11^{\text {th }}$ International Scientific and Practical Conference "Environment. Technology. Resources", vol. 1, Rezekne Higher Education Institution, Rezekne, pp. 246252. https://doi.org/10.17770/etr2017vol1.2585

32. *Saccone, P., Brun, J.J. \& Michalet, R. 2010: Challenging growth-survival trade-off: A key for Acer negundo invasion in European floodplains? Canadian Journal of Forest Research 40(10): 1879-1886. https://doi.org/10.1139/X10-134

33. *Saccone, P., Girel, J., Pages, J.P., Brun, J.J. \& Michalet, R. 2013: Ecological resistance to Acer negundo invasion in a European riparian forest: Relative importance of environmental and biotic drivers. Applied Vegetation Science 16(2): 184-192. https://doi. org/10.1111/j.1654-109X.2012.01227.x

34. *Saccone, P., Pagès, J.P., Girel, J., Brun, J.J. \& Michalet, R. 2010: Acer negundo invasion along a successional gradient: early direct facilitation by native pioneers and late indirect facilitation by conspecifics. New Phytologist 187(3): 831-842. https://doi. org/10.1111/j.1469-8137.2010.03289.x
35. *Säumel, I. \& Kowarik, I. 2010: Urban rivers as dispersal corridors for primarily wind-dispersed invasive tree species. Landscape and Urban Planning 94(3-4): 244-249. https://doi.org/10.1016/j.landurbplan.2009.10.009

36. *Säumel, I. \& Kowarik, I. 2013: Propagule morphology and river characteristics shape secondary water dispersal in tree species. Plant Ecology 214(10): 12571272. https://doi.org/10.1007/s11258-013-0249-z

37. *Spáčilová, B. \& Stredová, H. 2014: Disputed recreational and ecological stabilization functions of celected windbreaks. In: D. Pernicova, J. Fialova (eds.): Public Recreation and Landscape Protection - With Man Hand in Hand? Mendel University in Brno, Brno, pp. 85-91.

38. *Straigytè, L., Cekstere, G., Laivins, M. \& Marozas, V. 2015: The spread, intensity and invasiveness of the Acer negundo in Riga and Kaunas. Dendrobiology 74: 157-168. https://doi.org/10.12657/denbio.074.016

39. *Tabacchi, E. \& Planty-Tabacchi, A.M. 2003: Recent changes in Riparian vegetation: Possible consequences on dead wood processing along rivers. River Research and Applications 19(3): 251-263. https:// doi.org/10.1016/10.1002/rra.755

40. *Tafra, D., Pandža, M. \& Milović, M. 2012: Woody plants of the Omis. Sumarski List 136(11-12): 605-617.

41. *Veselkin, D.V., P'yankov, S.V., Safonov, M.A. \& Betekhtina, A.A. 2017: The structure of absorbing roots in invasive and native maple species. Russian Journal of Ecology 48(4): 303-310. https://doi. org/10.1134/S1067413617040166

42. *Veselkin, D.V., Kiseleva, O.A., Ekshibarov, E.D., Rafikova, O.S. \& Korzhinevskaya, A.A. 2018: Abundance and Diversity of Seedlings of the Soil Seed Bank in the Thickets of the Invasive Species Acer negundo L. Russian Journal of Biological Invasions 9(2): 108113. https://doi.org/10.1134/S2075111718020133

43. Veselkin, D.V., Korzhinevskaya, A.A. \& Podgaevskaya, E.N. 2018: The species composition and abundance of alien and invasive understory shrubs and trees in urban forests of Yekaterinburg. Vestnik Tomskogo Gosudarstvennogo Universiteta, Biologiya 42: 102-118. https://doi.org/10.17223/19988591/42/5

44. Yeremenko, N. 2019: Ruderal vegetation in Kryvyi Rih (Ukraine) - The class of Robinietea. Hacquetia, 18(1): 75-86. https://doi.org/10.2478/hacq-2018-0010

45. *Zajpler, M., Tyborski, J., Dyderski, M.K. \& Jagopziński, A.M. 2018: Dendroclimatological analysis of radial increments of invasive Acer negundo L. and Fraxinus pennsylvanica Marshall from the Warta river valley. Sylwan 162(7): 547-554. 
46. *Zelnik, I., Haler, M. \& Gaberscik, A. 2015: Vulnerability of a riparian zone towards invasion by alien plants depends on its structure. Biologia 70(7): 869878. https://doi.org/10.1515/biolog-2015-0110

\section{Bibliography of included papers on Robinia} pseudoacacia listed in alphabetical order of records (asterisk "*" indicate publications indexed in both databases)

\section{Bibliography of included papers from WoS CC}

1. *Akatov, V.V., Akatova, T.V. \& Shadzhe, A.E. 2012: Species richness of tree and shrub layers in riparian forests of the Western Caucasus dominated by alien species. Russian Journal of Ecology 43(4): 294-301. https://doi.org/10.1134/S1067413612040030

2. *Bandini, S. \& Pavesi, G. 2002: Simulation of vegetable populations dynamics based on cellular automata. In: Lecture Notes in Computer Science (including subseries Lecture Notes in Artificial Intelligence and Lecture Notes in Bioinformatics), vol. 2493 LNCS, pp. 202-209.

3. *Benesperi, R., Giuliani, C., Zanetti, S., Gennai, M., Mariotti Lippi, M., Guidi, T., Nascimbene, J. \& Foggi, B. 2012: Forest plant diversity is threatened by Robinia pseudoacacia (black-locust) invasion. Biodiversity and Conservation 21(14): 3555-3568. https://doi.org/10.1007/s10531-012-0380-5

4. *Berg, C., Drescher, A. \& Essl, F. 2017: Using relevébased metrics to explain invasion patterns of alien trees in temperate forests. Tuexenia 37(1): 127-142. https://doi.org/10.14471/2017.37.012

5. *Berg, C., Drescher, A., Wagner, V. \& Essl, F. 2016: Temporal trends in the invasions of Austrian woodlands by alien trees. Preslia 88(2): 185-200.

6. *Bomanowska, A., Rewicz, A., Wolski, G.J. \& Krasoń, K. 2017: Invasive alien plants in protected areas within city borders, Łódź, (Poland). Pakistan Journal of Botany 49(1): 311-316.

7. *Cabra-Rivas, I., Saldaña, A., Castro-Díez, P. \& Gallien, L. 2016: A multi-scale approach to identify invasion drivers and invaders' future dynamics. Biological Invasions 18(2): 411-426. https://doi.org/10.1007/ s10530-015-1015-z

8. *Campagnaro, T., Nascimbene, J., Tasinazzo, S., Trentanovi, G. \& Sitzia, T. 2018: Exploring patterns, drivers and structure of plant community composition in alien Robinia pseudoacacia secondary woodlands. IForest 11(5): 586-593. https://doi. org/10.3832/ifor2687-011

9. *Cavaletto, G., Mazzon, L., Faccoli, M. \& Marini, L. 2019: Habitat loss and alien tree invasion reduce defoliation intensity of an eruptive forest pest. Forest Ecology and Management 433: 497-503. https:// doi.org/10.1016/j.foreco.2018.11.028

10. *Crosti, R., Agrillo, E., Ciccarese, L., Guarino, R., Paris, P. \& Testi, A. 2016: Assessing escapes from short rotation plantations of the invasive tree species Robinia pseudoacacia L. in Mediterranean ecosystems: A study in central Italy. IForest 9(5): 822-828. https://doi.org/10.3832/ifor1526-009

11. *Čarni, A., Mastnak, N.J., Dakskobler, I., Kutnar, L., Marinšek, A. \& Šilc, U. 2017: Prediction of the appearance of tree of heaven in forestcommunities in western Slovenia. Periodicum Biologorum 119(4): 261-283. https://doi.org/10.18054/pb.v119i4.4483

12. *Çoban, S., Balekoğlu, S. \& Özalp, G. 2019: Change in plant species composition on powerline corridor: a case study. Environmental Monitoring and Assessment 191(4): 200. https://doi.org/10.1007/s10661019-7341-3

13. Dudkiewicz, M., Dabski, M., Durlak, W., Dudkiewicz, M., Dabski, M. \& Durlak, W. 2015: Dendroflora of historic park in Kijany. Acta Scientiarum Polonorum - Formatio Circumiectus 14(1): 15-25. https://doi.org/10.15576/ASP.FC/2015.14.1.15

14. *Dyderski, M.K. \& Jagodziński, A.M. 2018: Drivers of invasive tree and shrub natural regeneration in temperate forests. Biological Invasions 20(9): 23632379. https://doi.org/10.1007/s10530-018-1706-3

15. *Dyderski, M.K. \& Jagodziński, A.M. 2018: Low impact of disturbance on ecological success of invasive tree and shrub species in temperate forests. Plant Ecology 219(11): 1369-1380. https://doi. org/10.1007/s11258-018-0885-4

16. Dyderski, M.K. \& Jagodzinski, A.M. 2019: Functional traits of acquisitive invasive woody species differ from conservative invasive and native species. Neobiota 41: 91-113. https://doi.org/10.3897/neobiota.41.31908

17. *Essl, F., Milasowszky, N. \& Dirnböck, T. 2011: Plant invasions in temperate forests: Resistance or ephemeral phenomenon? Basic and Applied Ecology 12(1): 1-9. https://doi.org/10.1016/j.baae.2010.10.003

18. *Güsewell, S., Zuberbühler, N. \& Clerc, C. 2005: Distribution and functional traits of Solidago gigantea in a Swiss lakeshore wetland. Botanica Helvetica 115(1): 63-75. https://doi.org/10.1007/s00035-005-0721-z

19. *Hadjikyriakou, G. \& Hadjisterkotis, E. 2002: The adventive plants of Cyprus with new records of invasive species. Zeitschrift für Jagdwissenschaft 48 (Suppl.1): 59-71. https://doi.org/10.1007/BF02192393

20. *Hanzelka, J. \& Reif, J. 2015: Responses to the black locust (Robinia pseudoacacia) invasion differ 
between habitat specialists and generalists in central European forest birds. Journal of Ornithology 156(4): 1015-1024. https://doi.org/10.1007/s10336$015-1231-4$

21. *Hejda, M., Hanzelka, J., Kadlec, T., Štrobl, M., Pyšek, P. \& Reif, J. 2017: Impacts of an invasive tree across trophic levels: Species richness, community composition and resident species' traits. Diversity and Distributions 23(9): 997-1007. https://doi. org/10.1111/ddi.12596

22. *Höfle, R., Dullinger, S. \& Essl, F. 2014: Different factors affect the local distribution, persistence and spread of alien tree species in floodplain forests. Basic and Applied Ecology 15(5): 426-434. https://doi. org/10.1016/j.baae.2014.07.007

23. *Horvat, G. \& Franjić, J. 2016: Invasive plants of Kalnik forests. Sumarski List 140(1-2): 53-64.

24. *Hruška, K. 1991: Human impact on the forest vegetation in the western part of the Pannonic Plain (Yugoslavia). Vegetatio 92(2): 161-166. https://doi. org/10.1007/BF00036036

25. *Ivajnšič, D., Cousins, S.A.O. \& Kaligarič, M. 2012: Colonization by Robinia pseudoacacia of various soil and habitat types outside woodlands in a traditional Central-European agricultural landscape. Polish Journal of Ecology 60(2): 301-309.

26. *Kolyada, N.A. \& Kolyada, A.S. 2018. Robinia pseudoacacia L. (Fabaceae Lindl.) in the South of the Russian Far East. Russian Journal of Biological Invasions 9(3): 215-218. https://doi.org/10.1134/ S2075111718030062

27. *Kou, M., Garcia-Fayos, P., Hu, S. \& Jiao, J. 2016: The effect of Robinia pseudoacacia afforestation on soil and vegetation properties in the Loess Plateau (China): A chronosequence approach. Forest Ecology and Management 375: 146-158. https://doi. org/10.1016/j.foreco.2016.05.025

28. Kowarik, I. 1996: Functions of clonal growth in trees during wasteland succession with special reference to Robinia pseudoacacia. In: J. Pfadenhauer (ed.): $25^{\text {th }}$ Annual Meeting of the Gesellschaft-fur-Okologie "Verhandlungen der Gesellschaft fur Okologie", vol. 26, Dresden, Germany, pp. 173-181.

29. *Kowarik, I., Von Der Lippe, M. \& Cierjacks, A. 2013: Prevalence of alien versus native species of woody plants in Berlin differs between habitats and at different scales. Preslia 85(2): 113-132.

30. *Kroftová, M. \& Reif, J. 2017: Management implications of bird responses to variation in non-native/ native tree ratios within central European forest stands. Forest Ecology and Management 391: 330337. https://doi.org/10.1016/j.foreco.2017.02.034
31. *Kurokochi, H. \& Toyama, K. 2015: Invasive Tree Species Robinia pseudoacacia: A Potential Biomass Resource in Nagano Prefecture, Japan. Small-Scale Forestry 14(2): 205-215. https://doi.org/10.1007/ s11842-014-9282-6

32. *Lazzaro, L., Mazza, G., d'Errico, G., Fabiani, A., Giuliani, C., Inghilesi, A.F., Lagomarsino, A., Landi, S., Lastrucci, L., Pastorelli, R., Roversi, P.F., Torrini, G., Tricarico, E. \& Foggi, B. 2018: How ecosystems change following invasion by Robinia pseudoacacia: Insights from soil chemical properties and soil microbial, nematode, microarthropod and plant communities. Science of the Total Environment 622-623: 1509-1518. https://doi.org/10.1016/j.scitotenv.2017.10.017

33. ${ }^{*}$ Lee, C.S., Cho, H.J. \& Yi, H. 2004: Stand dynamics of introduced black locust (Robinia pseudoacacia L.) plantation under different disturbance regimes in Korea. Forest Ecology and Management 189(1-3): 281-293. https://doi.org/10.1016/j. foreco.2003.08.012

34. * Li, K., Yang, H., Han, X., Xue, L., Lv, Y., Li, J., Fu, Z., Li, C., Shen, W., Guo, H. \& Zhang, Y. 2018: Fractal features of soil particle size distributions and their potential as an indicator of Robinia pseudoacacia invasion. Scientific Reports 8(1): 7075. https://doi. org/10.1038/s41598-018-25543-0

35. *Maringer, J., Wohlgemuth, T., Neff, C., Pezzatti, G.B. \& Conedera, M. 2012: Post-fire spread of alien plant species in a mixed broad-leaved forest of the Insubric region. Flora: Morphology, Distribution, Functional Ecology of Plants 207(1): 19-29. https:// doi.org/10.1016/j.flora.2011.07.016

36. *Marozas, V., Cekstere, G., Laivins, M. \& Straigyte, L. 2015: Comparison of neophyte communities of Robinia pseudoacacia L. and Acer negundo L. in the eastern Baltic Sea region cities of Riga and Kaunas. Urban Forestry and Urban Greening 14(4): 826834. https://doi.org/10.1016/j.ufug.2015.08.003

37. *Masaka, K., Torita, H., Kon, H. \& Fukuchi, M. 2015: Seasonality of sprouting in the exotic tree Robinia pseudoacacia L. in Hokkaido, northern Japan. Journal of Forest Research 20(4): 386-395. https:// doi.org/10.1007/s10310-015-0488-z

38. *Masaka, K., Yamada, K., Koyama, Y., Sato, H., Kon, H. \& Torita, H. 2010: Changes in size of soil seed bank in Robinia pseudoacacia L. (Leguminosae), an exotic tall tree species in Japan: Impacts of stand growth and apicultural utilization. Forest Ecology and Management 260(5): 780-786. https:// doi.org/10.1016/j.foreco.2010.05.036 
39. *Masaka, K., Yamada, K., Sato, H., Torita, H. \& Kon, H. 2013: Understory plant richness and native tree invasion in exotic Robinia pseudoacacia stands in Hokkaido, Japan. Forest Science 59(5): 589-597. https://doi.org/10.5849/forsci.11-106

40. Molitoris, L. 2013: Fallopia japonica Houtt. and Robinia pseudoacacia L., an increasingly intractable plant problem or not understood opportunity? In: P. Skarpa, P. Ryant, R. Cerkal, O. Polak, J. Kovarnik (eds.): $20^{\text {th }}$ International $\mathrm{PhD}$ Students Conference "MENDELNET 2013", Brno, pp. 331-335.

41. *Morimoto, J., Kominami, R. \& Koike, T. 2010: Distribution and characteristics of the soil seed bank of the black locust (Robinia pseudoacacia) in a headwater basin in northern Japan. Landscape and Ecological Engineering 6(2): 193-199. https://doi. org/10.1007/s11355-009-0096-1

42. *Motta, R., Nola, P. \& Berretti, R. 2009: The rise and fall of the black locust (Robinia pseudoacacia L.) in the "Siro Negri" Forest Reserve (Lombardy, Italy): Lessons learned and future uncertainties. Annals of Forest Science 66(4): 410p1-410p10. https://doi. org/10.1051/forest/2009012

43. Nadal-Sala, D., Sabate, S., Ssnchez-Costa, E., Boumghar, A. \& Gracia, C.A. 2013: Different Responses to Water Availability and Evaporative Demand of Four Co-Occurring Riparian Tree Species in NE Iberian Peninsula: Temporal and Spatial Sap Flow Patterns. In: K. Steppe (ed.): IX International Workshop on Sap Flow, Ghent, Belgium, pp. 215-222.

44. *Nascimbene, J. \& Marini, L. 2010: Oak forest exploitation and black-locust invasion caused severe shifts in epiphytic lichen communities in Northern Italy. Science of the Total Environment 408(22): 5506-5512. https://doi.org/10.1016/j. scitotenv.2010.07.056

45. ${ }^{*}$ Nascimbene, J., Nimis, P.L. \& Benesperi, R. 2012: Mature non-native black-locust (Robinia pseudoacacia L.) forest does not regain the lichen diversity of the natural forest. Science of the Total Environment (421-422): 197-202. https://doi.org/10.1016/j.scitotenv.2012.01.051

46. Pace, L. \& Tammaro, F. 2001: The main invasive alien plants in the protected areas in Central Italy (Abruzzo) - Invasive alien organisms. In: G. Visconti, M. Beniston, E.D. Iannorelli, D. Barba (eds.): Global Change and Protected Areas, vol. 9, Laquila, Italy, pp. 495-504.

47. Platen, R. \& Kowarik, I. 1995: Dynamics of plant, spider and ground beetle communities in the succession from dry grassland to woodland at fallow urban railway sites in Berlin. In: J. Pfadenhauer (ed.): $24^{\text {th }}$ Annual Meeting of the Gesellschaft-fur-Okologie "Verhandlungen der Gesellschaft fur Okologie", vol. 24, Dresden, Germany, pp. 431-439.

48. Porcova, L. \& Wikler, J. 2014: The effect of the different vineyard management to composition of weed species. In: O. Polak, R. Cerkal, P. Skarpa (eds.): $21^{\text {st }}$ International $\mathrm{PhD}$ Students Conference "MENDELNET 2014", Brno, pp. 90-94.

49. *Radtke, A., Ambraß, S., Zerbe, S., Tonon, G., Fontana, V. \& Ammer, C. 2013: Traditional coppice forest management drives the invasion of Ailanthus altissima and Robinia pseudoacacia into deciduous forests. Forest Ecology and Management 291: 308317. https://doi.org/10.1016/j.foreco.2012.11.022

50. *Rawlik, M., Kasprowicz, M., Jagodziński, A.M., Kaźmierowski, C., Łukowiak, R. \& Grzebisz, W. 2018: Canopy tree species determine herb layer biomass and species composition on a reclaimed mine spoil heap. Science of the Total Environment 635: 1205-1214. https://doi.org/10.1016/j.scitotenv.2018.04.133

51. *Schiffleithner, V. \& Essl, F. 2016: Is it worth the effort? Spread and management success of invasive alien plant species in a Central European National Park. NeoBiota 31: 43-61. https://doi.org/10.3897/ neobiota.31.8071

52. *Sitzia, T., Campagnaro, T., Dainese, M. \& Cierjacks, A. 2012: Plant species diversity in alien black locust stands: A paired comparison with native stands across a north-Mediterranean range expansion. Forest Ecology and Management 285: 85-91. https:// doi.org/10.1016/j.foreco.2012.08.016

53. *Sitzia, T., Campagnaro, T., Kotze, D.J., Nardi, S. \& Ertani, A. 2018: The invasion of abandoned fields by a major alien tree filters understory plant traits in novel forest ecosystems. Scientific Reports 8(1): 8410. https://doi.org/10.1038/s41598-018-26493-3

54. *Slabejová, D., Bacigál, T., Hegedüšová, K., Májeková, J., Medvecká, J., Mikulová, K., Šibíková, M., Škodová, I., Zaliberová, M. \& Jarolímek, I. 2019: Comparison of the understory vegetation of native forests and adjacent Robinia pseudoacacia plantations in the Carpathian-Pannonian region. Forest Ecology and Management, 439: 28-40. https://doi. org/10.1016/j.foreco.2019.02.039

55. *Song, I.J., Hong, S.K., Kim, H.O., Byun, B. \& Gin, Y. 2005: The pattern of landscape patches and invasion of naturalized plants in developed areas of urban Seoul. Landscape and Urban Planning 70(34): 205-219. https://doi.org/10.1016/j.landurbplan.2003.10.018 
56. * Staska, B., Essl, F. \& Samimi, C. 2014: Density and age of invasive Robinia pseudoacacia modulate its impact on floodplain forests. Basic and Applied Ecology 15(6): 551-558. https://doi.org/10.1016/j. baae.2014.07.010

57. *Tafra, D., Pandža, M. \& Milović, M. 2012: Woody plants of the Omis. Sumarski List 136(11-12): 605-617.

58. *Taniguchi, T., Tamai, S., Yamanaka, N. \& Futai, K. 2007: Inhibition of the regeneration of Japanese black pine (Pinus thunbergii) by black locust (Robinia pseudoacacia) in coastal sand dunes. Journal of Forest Research 12(5): 350-357. https://doi.org/10.1007/ s10310-007-0023-y

59. *Terwei, A., Zerbe, S., Mölder, I., Annighöfer, P., Kawaletz, H. \& Ammer, C. 2016: Response of floodplain understorey species to environmental gradients and tree invasion: a functional trait perspective. Biological Invasions 18(10): 2951-2973. https://doi. org/10.1007/s10530-016-1188-0

60. ${ }^{*}$ Terwei, A., Zerbe, S., Zeileis, A., Annighöfer, P., Kawaletz, H., Mölder, I. \& Ammer, C. 2013: Which are the factors controlling tree seedling establishment in North Italian floodplain forests invaded by non-native tree species? Forest Ecology and Management 304: 192-203. https://doi.org/10.1016/j. foreco.2013.05.003

61. *Trentanovi, G., von der Lippe, M., Sitzia, T., Ziechmann, U., Kowarik, I. \& Cierjacks, A. 2013: Biotic homogenization at the community scale: Disentangling the roles of urbanization and plant invasion. Diversity and Distributions 19(7): 738-748. https:// doi.org/10.1111/ddi.12028

62. *Vasilopoulos, G., Tsiripidis, I. \& Karagiannakidou, V. 2007: Do abandoned tree plantations resemble natural riparian forests? A case study from northeast Greece. Botanica Helvetica 117(2): 125-142. https://doi.org/10.1007/s00035-007-0796-9

63. *von Holle, B., Neill, C., Largay, E.F., Budreski, K.A., Ozimec, B., Clark, S.A. \& Lee, K. 2013: Ecosystem legacy of the introduced $\mathrm{N}_{2}$-fixing tree Robinia pseudoacacia in a coastal forest. Oecologia 172(3): 915-924. https://doi.org/10.1007/s00442012-2543-1

64. *Wang, Y., Wang, Q.-X. \& Wang, M.-B. 2018: Similar carbon density of natural and planted forests in the Lüliang Mountains, China. Annals of Forest Science 75(3): 87. https://doi.org/10.1007/s13595018-0753-3

65. *Young, C.C., Bell, J.C., Gross, C.S., Morrison, L.W. \& Haack-Gaynor, J.L. 2017: Point Mapping Integrates Data Collection and Weed Control Op- erations. Invasive Plant Science and Management 10(1): 33-43. https://doi.org/10.1017/inp.2017.5

66. *Zelnik, I., Haler, M. \& Gaberscik, A. 2015: Vulnerability of a riparian zone towards invasion by alien plants depends on its structure. Biologia 70(7): 869878. https://doi.org/10.1515/biolog-2015-0110

67. *Zhao, B., Guo, D., Shao, H. \& Bai, Z. 2017: Investigating the population structure and spatial pattern of restored forests in an opencast coal mine, China. Environmental Earth Sciences 76(20): 679.

\section{Bibliography of included papers from Scopus}

1. *Akatov, V.V., Akatova, T.V. \& Shadzhe, A.E. 2012: Species richness of tree and shrub layers in riparian forests of the Western Caucasus dominated by alien species. Russian Journal of Ecology 43(4): 294-301. https://doi.org/10.1134/S1067413612040030

2. Ambrass, V.S., Radtke, A., Zerbe, S., Fontana, V. \& Ammer, C. 2014: Propagation and management of ailanthus and black locust in coppice forests: Insights from a case study on invasive species in South Tyrol. Naturschutz und Landschaftsplanung 46(2): 45-51.

3. Banaszek, J., Leksy, M. \& Rahmonov, O. 2017: The role of spontaneous succession in reclamation of mining waste tip in area of Ruda Śląska city. In: $10^{\text {th }}$ International Conference on Environmental Engineering, ICEE 2017, Article enviro.2017.098. https://doi.org/10.3846/enviro.2017.098

4. *Bandini, S. \& Pavesi, G. 2002: Simulation of vegetable populations dynamics based on cellular automata. In: Lecture Notes in Computer Science (including subseries Lecture Notes in Artificial Intelligence and Lecture Notes in Bioinformatics), vol. 2493 LNCS, pp. 202-209.

5. Bartus, P., Baráz, C. \& Malatinszky, Á. 2018: Landscape changes in a 19th century wood pasture and grazing forest (2018) Hungarian Geographical Bulletin 67(1): 13-27. https://doi.org/10.15201/hungeobull.67.1.2

6. Bazalová, D., Botková, K., Hegedüšová, K., Májeková, J., Medvecká, J., Šibíková, M., Škodová, I., Zaliberová, M. \& Jarolímek, I. 2018: Twin plotsappropriate method to assess the impact of alien tree on understory? Hacquetia 17(2): 163-169. https:// doi.org/10.1515/hacq-2017-0012

7. *Benesperi, R., Giuliani, C., Zanetti, S., Gennai, M., Mariotti Lippi, M., Guidi, T., Nascimbene, J. \& Foggi, B. 2012: Forest plant diversity is threatened by Robinia pseudoacacia (black-locust) invasion. Biodiversity and Conservation 21(14): 3555-3568. https://doi.org/10.1007/s10531-012-0380-5 
8. *Berg, C., Drescher, A. \& Essl, F. 2017: Using relevébased metrics to explain invasion patterns of alien trees in temperate forests. Tuexenia 37(1): 127-142. https://doi.org/10.14471/2017.37.012

9. *Berg, C., Drescher, A., Wagner, V. \& Essl, F. 2016: Temporal trends in the invasions of Austrian woodlands by alien trees. Preslia 88(2): 185-200.

10. *Bomanowska, A., Rewicz, A., Wolski, G.J. \& Krasoń, K. 2017: Invasive alien plants in protected areas within city borders, Łódź, (Poland). Pakistan Journal of Botany 49(1): 311-316.

11. Bonari, G., Cantini, D., Angiolini, C., Selvi, F., Scoppola, A., Viciani, D., Ferretti, G., Gabellini, A., Perini, C., De Dominicis, V., Ardenghi, N.M.G. \& Lastrucci, L. 2016: Contribution to the vascular flora of Pietraporciana Nature Reserve (Southern Tuscany, Italy). Atti della Societa Toscana di Scienze Naturali, Memorie Serie B 123: 9-28. https://doi. org/10.2424/ASTSN.M.2016.02

12. *Cabra-Rivas, I., Saldaña, A., Castro-Díez, P. \& Gallien, L. 2016: A multi-scale approach to identify invasion drivers and invaders' future dynamics. Biological Invasions 18(2): 411-426. https://doi.org/10.1007/ s10530-015-1015-z

13. ${ }^{*}$ Campagnaro, T., Nascimbene, J., Tasinazzo, S., Trentanovi, G. \& Sitzia, T. 2018: Exploring patterns, drivers and structure of plant community composition in alien Robinia pseudoacacia secondary woodlands. IForest 11(5): 586-593. https://doi. org/10.3832/ifor2687-011

14. *Cavaletto, G., Mazzon, L., Faccoli, M. \& Marini, L. 2019: Habitat loss and alien tree invasion reduce defoliation intensity of an eruptive forest pest. Forest Ecology and Management 433: 497-503. https:// doi.org/10.1016/j.foreco.2018.11.028

15. ${ }^{*}$ Crosti, R., Agrillo, E., Ciccarese, L., Guarino, R., Paris, P. \& Testi, A. 2016: Assessing escapes from short rotation plantations of the invasive tree species Robinia pseudoacacia L. in Mediterranean ecosystems: A study in central Italy. IForest 9(5): 822-828. https://doi.org/10.3832/ifor1526-009

16. *Čarni, A., Mastnak, N.J., Dakskobler, I., Kutnar, L., Marinšek, A. \& Šilc, U. 2017: Prediction of the appearance of tree of heaven in forestcommunities in western Slovenia. Periodicum Biologorum 119(4): 261-283. https://doi.org/10.18054/pb.v119i4.4483

17. ${ }^{*}$ Çoban, S., Balekoğlu, S. \& Özalp, G. 2019: Change in plant species composition on powerline corridor: a case study. Environmental Monitoring and Assessment 191(4): 200. https://doi.org/10.1007/s10661019-7341-3

18. *Dyderski, M.K. \& Jagodziński, A.M. 2018: Driv- ers of invasive tree and shrub natural regeneration in temperate forests. Biological Invasions 20(9): 23632379. https://doi.org/10.1007/s10530-018-1706-3

19. *Dyderski, M.K. \& Jagodziński, A.M. 2018: Low impact of disturbance on ecological success of invasive tree and shrub species in temperate forests. Plant Ecology 219(11): 1369-1380. https://doi. org/10.1007/s11258-018-0885-4

20. *Essl, F., Milasowszky, N. \& Dirnböck, T. 2011: Plant invasions in temperate forests: Resistance or ephemeral phenomenon? Basic and Applied Ecology 12(1): 1-9. https://doi.org/10.1016/j.baae.2010.10.003

21. Glišić, M., Lakušić, O., Šinžar-Sekulić, J. \& Jovanović, S. 2014: GIS analysis of spatial distribution of invasive tree species in the protected natural area of Mt. Avala (Serbia). Botanica Serbica 38(1): 131-138.

22. Grigorov, B. 2016: Invasive plant species in the northern part of Mala Planina. In: Koulov B., Zhelezov G. (eds.): Sustainable Mountain Regions: Challenges and Perspectives in Southeastern Europe. Springer International Publishing, pp. 219-229. https://doi. org/10.1007/978-3-319-27905-3_16

23. *Güsewell, S., Zuberbühler, N. \& Clerc, C. 2005: Distribution and functional traits of Solidago gigantea in a Swiss lakeshore wetland. Botanica Helvetica 115(1): 63-75. https://doi.org/10.1007/s00035005-0721-z

24. *Hadjikyriakou, G. \& Hadjisterkotis, E. 2002: The adventive plants of Cyprus with new records of invasive species. Zeitschrift für Jagdwissenschaft 48(Suppl.1): 59-71. https://doi.org/10.1007/BF02192393

25. *Hanzelka, J. \& Reif, J. 2015: Responses to the black locust (Robinia pseudoacacia) invasion differ between habitat specialists and generalists in central European forest birds. Journal of Ornithology 156(4): 10151024. https://doi.org/10.1007/s10336-015-1231-4

26. Hashimoto, Y., Hattori, T., Kodate, S., Minamiyama, N. \& Akamatsu, H. 2005: Distribution of the alien species Robinia pseudoacacia L. in the Inagawa River in Hyogo Prefecture, western Japan. Humans and Nature 15: 61-68.

27. *Hejda, M., Hanzelka, J., Kadlec, T., Štrobl, M., Pyšek, P. \& Reif, J. 2017: Impacts of an invasive tree across trophic levels: Species richness, community composition and resident species' traits. Diversity and Distributions 23(9): 997-1007. https://doi. org/10.1111/ddi.12596

28. *Höfle, R., Dullinger, S. \& Essl, F. 2014: Different factors affect the local distribution, persistence and spread of alien tree species in floodplain forests. Basic and Applied Ecology 15(5): 426-434. https://doi. org/10.1016/j.baae.2014.07.007 
29. *Horvat, G. \& Franjić, J. 2016: Invasive plants of Kalnik forests. Sumarski List 140(1-2): 53-64.

30. ${ }^{*}$ Hruška, K. 1991: Human impact on the forest vegetation in the western part of the Pannonic Plain (Yugoslavia). Vegetatio 92(2): 161-166. https://doi. org/10.1007/BF00036036

31. Idžojtić, M. \& Zebec, M. 2006: Distribution of the tree of heaven (Ailanthus altissima (Mill.) Swingle) and spreading of invasive woody alien species in Croatia. Glasnik za Sumske Pokuse 5(Special Issue): 315-323.

32. *Ivajnšič, D., Cousins, S.A.O. \& Kaligarič, M. 2012: Colonization by Robinia pseudoacacia of various soil and habitat types outside woodlands in a traditional Central-European agricultural landscape. Polish Journal of Ecology 60(2): 301-309.

33. Kirpluk, I. 2012: The most recent alien species of the ruderal flora in the abandoned villages of the Kampinos National Park (Central Poland). Thaiszia Journal of Botany 22(2): 143-153.

34. ${ }^{*}$ Kolyada, N.A. \& Kolyada, A.S. 2018. Robinia pseudoacacia L. (Fabaceae Lindl.) in the South of the Russian Far East. Russian Journal of Biological Invasions 9(3): 215-218. https://doi.org/10.1134/ S2075111718030062

35. *Kou, M., Garcia-Fayos, P., Hu, S. \& Jiao, J. 2016: The effect of Robinia pseudoacacia afforestation on soil and vegetation properties in the Loess Plateau (China): A chronosequence approach. Forest Ecology and Management 375: 146-158. https://doi. org/10.1016/j.foreco.2016.05.025

36. ${ }^{*}$ Kowarik, I., Von Der Lippe, M. \& Cierjacks, A. 2013: Prevalence of alien versus native species of woody plants in Berlin differs between habitats and at different scales. Preslia 85(2): 113-132.

37. *Kroftová, M. \& Reif, J. 2017: Management implications of bird responses to variation in non-native/ native tree ratios within central European forest stands. Forest Ecology and Management 391: 330 337. https://doi.org/10.1016/j.foreco.2017.02.034

38. Kurokochi, H. \& Hogetsu, T. 2014: Fine-scale initiation of non-native Robinia pseudoacacia riparian forests along the Chikumagawa River in central Japan. Journal of Ecology and Environment 37(1): 21-29. https://doi.org/10.5141/ecoenv.2014.003

39. ${ }^{*}$ Kurokochi, H. \& Toyama, K. 2015: Invasive Tree Species Robinia pseudoacacia: A Potential Biomass Resource in Nagano Prefecture, Japan. Small-Scale Forestry 14(2): 205-215. https://doi.org/10.1007/ s11842-014-9282-6

40. *Lazzaro, L., Mazza, G., d'Errico, G., Fabiani, A., Giuliani, C., Inghilesi, A.F., Lagomarsino, A., Landi, S., Lastrucci, L., Pastorelli, R., Roversi, P.F., Torrini,
G., Tricarico, E. \& Foggi, B. 2018: How ecosystems change following invasion by Robinia pseudoacacia: Insights from soil chemical properties and soil microbial, nematode, microarthropod and plant communities. Science of the Total Environment 622-623: 1509-1518. https://doi.org/10.1016/j.scitotenv.2017.10.017

41. *Lee, C.S., Cho, H.J. \& Yi, H. 2004: Stand dynamics of introduced black locust (Robinia pseudoacacia L.) plantation under different disturbance regimes in Korea. Forest Ecology and Management 189(1-3): 281-293. https://doi.org/10.1016/j. foreco.2003.08.012

42. ${ }^{*}$ Li, K., Yang, H., Han, X., Xue, L., Lv, Y., Li, J., Fu, Z., Li, C., Shen, W., Guo, H. \& Zhang, Y. 2018: Fractal features of soil particle size distributions and their potential as an indicator of Robinia pseudoacacia invasion. Scientific Reports 8(1): 7075. https://doi. org/10.1038/s41598-018-25543-0

43. Li, M., Hairong, H., Qinyan, M. \& Shuli, D. 2010: Establishment and application of the synthetic assessment system of forest ecosystem health in Beijing area. In: J.A. Daniels (ed.): Advances in Environmental Research, vol. 4, NY, Nova Science Publishers, Inc., pp. 121-139.

44. Li, M., Hairong, H., Qinyan, M. \& Shuli, D. 2011: Establishment and application of the synthetic assessment system of forest ecosystem health in Beijing area. In: D.A. Boehm (ed.): Forestry: Research, Ecology and Policies, NY: Nova Science Publishers, Inc., pp. 167-186.

45. *Maringer, J., Wohlgemuth, T., Neff, C., Pezzatti, G.B. \& Conedera, M. 2012: Post-fire spread of alien plant species in a mixed broad-leaved forest of the Insubric region. Flora: Morphology, Distribution, Functional Ecology of Plants 207(1): 19-29. https:// doi.org/10.1016/j.flora.2011.07.016

46. *Marozas, V., Cekstere, G., Laivins, M. \& Straigyte, L. 2015: Comparison of neophyte communities of Robinia pseudoacacia L. and Acer negundo L. in the eastern Baltic Sea region cities of Riga and Kaunas. Urban Forestry and Urban Greening 14(4): 826834. https://doi.org/10.1016/j.ufug.2015.08.003

47. *Masaka, K., Torita, H., Kon, H. \& Fukuchi, M. 2015: Seasonality of sprouting in the exotic tree Robinia pseudoacacia L. in Hokkaido, northern Japan. Journal of Forest Research 20(4): 386-395. https:// doi.org/10.1007/s10310-015-0488-z

48. *Masaka, K., Yamada, K., Koyama, Y., Sato, H., Kon, H. \& Torita, H. 2010: Changes in size of soil seed bank in Robinia pseudoacacia L. (Leguminosae), an exotic tall tree species in Japan: Impacts of stand 
growth and apicultural utilization. Forest Ecology and Management 260(5): 780-786. https://doi. $\mathrm{org} / 10.1016 /$ j.foreco.2010.05.036

49. *Masaka, K., Yamada, K., Sato, H., Torita, H. \& Kon, H. 2013: Understory plant richness and native tree invasion in exotic Robinia pseudoacacia stands in Hokkaido, Japan. Forest Science 59(5): 589-597. https://doi.org/10.5849/forsci.11-106

50. ${ }^{*}$ Morimoto, J., Kominami, R. \& Koike, T. 2010: Distribution and characteristics of the soil seed bank of the black locust (Robinia pseudoacacia) in a headwater basin in northern Japan. Landscape and Ecological Engineering 6(2): 193-199. https://doi. org/10.1007/s11355-009-0096-1

51. *Motta, R., Nola, P. \& Berretti, R. 2009: The rise and fall of the black locust (Robinia pseudoacacia L.) in the "Siro Negri" Forest Reserve (Lombardy, Italy): Lessons learned and future uncertainties. Annals of Forest Science 66(4): 410p1-410p10. https://doi. org/10.1051/forest/2009012

52. Möllerová, J. 2005: Notes on invasive and expansive trees and shrubs. Journal of Forest Science 51: 19-23.

53. *Nascimbene, J. \& Marini, L. 2010: Oak forest exploitation and black-locust invasion caused severe shifts in epiphytic lichen communities in Northern Italy. Science of the Total Environment 408(22): 5506-5512. https://doi.org/10.1016/j.scitotenv.2010.07.056

54. *Nascimbene, J., Nimis, P.L. \& Benesperi, R. 2012: Mature non-native black-locust (Robinia pseudoacacia L.) forest does not regain the lichen diversity of the natural forest. Science of the Total Environment (421-422): 197-202. https://doi.org/10.1016/j.scitotenv.2012.01.051

55. Otto, R. \& Verloove, F. 2018: New xenophytes from la Palma (Canary Islands, Spain), with emphasis on naturalized and (potentially) invasive speciesPart 2. Collectanea Botanica 37: e005. https://doi. org/10.3989/collectbot.2018.v37.005

56. Pauková, Z. 2013: Invasive plant species in the three microregions of Nitra region, south-west Slovakia. Ekologia Bratislava 32(2): 262-266. https://doi. org/10.2478/eko-2013-0022

57. *Radtke, A., Ambraß, S., Zerbe, S., Tonon, G., Fontana, V. \& Ammer, C. 2013: Traditional coppice forest management drives the invasion of Ailanthus altissima and Robinia pseudoacacia into deciduous forests. Forest Ecology and Management 291: 308317. https://doi.org/10.1016/j.foreco.2012.11.022

58. *Rawlik, M., Kasprowicz, M., Jagodziński, A.M., Kaźmierowski, C., Łukowiak, R. \& Grzebisz, W. 2018: Canopy tree species determine herb layer biomass and species composition on a reclaimed mine spoil heap. Science of the Total Environment 635: 1205-1214. https://doi.org/10.1016/j.scitotenv.2018.04.133

59. Sakio, H. 2003: Can an exotic plant, Robinia pseudoacacia L., be removed from riparian ecosystems in Japan. Journal of the Japanese Forestry Society 85(4): 355-358.

60. * Schiffleithner, V. \& Essl, F. 2016: Is it worth the effort? Spread and management success of invasive alien plant species in a Central European National Park. NeoBiota 31: 43-61. https://doi.org/10.3897/ neobiota.31.8071

61. *Sitzia, T., Campagnaro, T., Dainese, M. \& Cierjacks, A. 2012: Plant species diversity in alien black locust stands: A paired comparison with native stands across a north-Mediterranean range expansion. Forest Ecology and Management 285: 85-91. https:// doi.org/10.1016/j.foreco.2012.08.016

62. *Sitzia, T., Campagnaro, T., Kotze, D.J., Nardi, S. \& Ertani, A. 2018: The invasion of abandoned fields by a major alien tree filters understory plant traits in novel forest ecosystems. Scientific Reports 8(1): 8410. https://doi.org/10.1038/s41598-018-26493-3

63. *Slabejová, D., Bacigál, T., Hegedüšová, K., Májeková, J., Medvecká, J., Mikulová, K., Šibíková, M., Škodová, I., Zaliberová, M. \& Jarolímek, I. 2019: Comparison of the understory vegetation of native forests and adjacent Robinia pseudoacacia plantations in the Carpathian-Pannonian region. Forest Ecology and Management, 439: 28-40. https://doi. org/10.1016/j.foreco.2019.02.039

64. Slodowicz, D., Kikodze, D., Khutsishvili, M., Kalatozishvili, L. \& Müller-Schärer, H. 2018: Monitoring of invasive alien plants in protected areas of Georgia. Bulletin of the Georgian National Academy of Sciences 12(2): 111-116.

65. * Song, I.J., Hong, S.K., Kim, H.O., Byun, B. \& Gin, Y. 2005: The pattern of landscape patches and invasion of naturalized plants in developed areas of urban Seoul. Landscape and Urban Planning 70(3-4): 205-219. https://doi.org/10.1016/j.landurbplan.2003.10.018

66. *Staska, B., Essl, F. \& Samimi, C. 2014: Density and age of invasive Robinia pseudoacacia modulate its impact on floodplain forests. Basic and Applied Ecology 15(6): 551-558. https://doi.org/10.1016/j. baae.2014.07.010

67. Stinca, A. \& Motti, R. 2017: Alien plant invasions in Astroni crater, a decades-long unmanaged forest in southern Italy. Atti della Societa Toscana di Scienze Naturali, Memorie Serie B 124: 101-108. https:// doi.org/10.2424/ASTSN.M.2017.10 
68. Sutyinszki, Zs. \& Szentes, Sz. 2014: Monitoring the habitat of protected plant species in verges near Kondoros (SE Hungary). Journal of Landscape Ecology 12(2): 345-354.

69. Sytnyk, S., Lovynska, V., Lakyda, P. \& Maslikova, K. 2018: Basic density and crown parameters of forest forming species within Steppe zone in Ukraine. Folia Oecologica 45(2): 82-91. https://doi.org/10.2478/ foecol-2018-0009

70. *Tafra, D., Pandža, M. \& Milović, M. 2012: Woody plants of the Omis. Sumarski List 136(11-12): 605-617.

71. Takahashi, A., Koyama, H. \& Takahashi, N. 2008: Habitat expansion of Robinia pseudoacacia L. and role of seed banks in the Akagawa River basin. Journal of the Japanese Forestry Society 90(1): 1-5.

72. *Taniguchi, T., Tamai, S., Yamanaka, N. \& Futai, K. 2007: Inhibition of the regeneration of Japanese black pine (Pinus thunbergii) by black locust (Robinia pseudoacacia) in coastal sand dunes. Journal of Forest Research 12(5): 350-357. https://doi.org/10.1007/ s10310-007-0023-y

73. *Terwei, A., Zerbe, S., Mölder, I., Annighöfer, P., Kawaletz, H. \& Ammer, C. 2016: Response of floodplain understorey species to environmental gradients and tree invasion: a functional trait perspective. Biological Invasions 18(10): 2951-2973. https://doi. org/10.1007/s10530-016-1188-0

74. ${ }^{*}$ Terwei, A., Zerbe, S., Zeileis, A., Annighöfer, P., Kawaletz, H., Mölder, I. \& Ammer, C. 2013: Which are the factors controlling tree seedling establishment in North Italian floodplain forests invaded by non-native tree species? Forest Ecology and Management 304: 192-203. https://doi.org/10.1016/j. foreco.2013.05.003

75. *Trentanovi, G., von der Lippe, M., Sitzia, T., Ziechmann, U., Kowarik, I. \& Cierjacks, A. 2013: Biotic homogenization at the community scale: Disentangling the roles of urbanization and plant invasion. Diversity and Distributions 19(7): 738-748. https:// doi.org/10.1111/ddi.12028

76. *Vasilopoulos, G., Tsiripidis, I. \& Karagiannakidou, V. 2007: Do abandoned tree plantations resemble natural riparian forests? A case study from northeast Greece. Botanica Helvetica 117(2): 125-142. https://doi.org/10.1007/s00035-007-0796-9

77. Vautier, F., Peiry, J.-L. \& Girel, J. 2002: Vegetation development in the embanked channel of the Isère river upstream from Grenoble (French Alps): From the diagnosis to the evaluation of the practices of management. Revue d'Ecologie (La Terre et la Vie) 57(Suppl. 2): 65-79.
78. Vološčuk, I. 2012: Changes in forest phytodiversity caused by alien woody plants in Štiavnické vrchy Mts. Thaiszia Journal of Botany 22(2): 105-119.

79. *von Holle, B., Neill, C., Largay, E.F., Budreski, K.A., Ozimec, B., Clark, S.A. \& Lee, K. 2013: Ecosystem legacy of the introduced $\mathrm{N}_{2}$-fixing tree Robinia pseudoacacia in a coastal forest. Oecologia 172(3): 915-924. https://doi.org/10.1007/s00442012-2543-1

80. Wang, S., Zhang, N., Yu, L., Zhao, R., Hao, P., Li, J., Jiang, Y., Sha, H., Liu, Y. \& Zhang, Z. 2012: Distribution pattern and their influcing factors of invasive alien plants in Beijing. Acta Ecologica Sinica 32(15): 4618-4629. https://doi.org/10.5846/ stxb201201120064

81. *Wang, Y., Wang, Q.-X. \& Wang, M.-B. 2018: Similar carbon density of natural and planted forests in the Lüliang Mountains, China. Annals of Forest Science 75(3): 87. https://doi.org/10.1007/s13595018-0753-3

82. Wei, J., Li, Z., Jiao, L., Chen, W., Wu, X., Wang, X. \& Wang, S. 2018: Climate effect on the radial growth of introduced and native tree species in the Yangjuangou catchment of the Loess Plateau. Acta Ecologica Sinica 38(22): 8040-8050. https://doi. org/10.5846/stxb201801100079

83. Yamada, K. \& Masaka, K. 2007: Present distribution and historical background of the invasive alien species Robinia pseudoacacia on former coalmine land in Hokkaido. Japanese Journal of Conservation Ecology 12(2): 94-102.

84. Yamada, K. \& Masaka, K. 2009: Dynamics in growth and survivals of Robinia psendoacacia sprouts occurred after cutting conducted in different seasons. Journal of the Japanese Forestry Society 91(1): 42-45.

85. Yeremenko, N. 2019: Ruderal vegetation in Kryvyi Rih (Ukraine) - The class of Robinietea. Hacquetia, 18(1): 75-86. https://doi.org/10.2478/hacq-20180010

86. *Young, C.C., Bell, J.C., Gross, C.S., Morrison, L.W. \& Haack-Gaynor, J.L. 2017: Point Mapping Integrates Data Collection and Weed Control Operations. Invasive Plant Science and Management 10(1): 33-43. https://doi.org/10.1017/inp.2017.5

87. *Zelnik, I., Haler, M. \& Gaberscik, A. 2015: Vulnerability of a riparian zone towards invasion by alien plants depends on its structure. Biologia 70(7): 869878. https://doi.org/10.1515/biolog-2015-0110

88. *Zhao, B., Guo, D., Shao, H. \& Bai, Z. 2017: Investigating the population structure and spatial pattern of restored forests in an opencast coal mine, China. Environmental Earth Sciences 76(20): 679. 
Bibliography of included papers on Ailanthus altissima listed in alphabetical order of records (asterisk "*" indicate publications indexed in both databases)

\section{Bibliography of included papers from WoS CC}

1. *Affre, L., Suehs, C.M., Charpentier, S., Vilà, M., Brundu, G., Lambdon, P., Traveset, A. \& Hulme, P.E. 2010: Consistency in the habitat degree of invasion for three invasive plant species across Mediterranean islands. Biological Invasions 12(8): 2537-2548. https://doi.org/10.1007/s10530-009-9662-6

2. *Akatov, V.V., Akatova, T.V. \& Shadzhe, A.E. 2012: Species richness of tree and shrub layers in riparian forests of the Western Caucasus dominated by alien species. Russian Journal of Ecology 43(4): 294-301. https://doi.org/10.1134/S1067413612040030

3. *Anderson, M. \& Crosby, M.K. 2018: An assessment of invasive plants on Shorter University's Campus. Mathematical and Computational Forestry \& Natural Resource Sciences 10(1): 24-29.

4. *Berg, C., Drescher, A., Wagner, V. \& Essl, F. 2016: Temporal trends in the invasions of Austrian woodlands by alien trees. Preslia 88(2): 185-200.

5. *Berg, C., Drescher, A. \& Essl, F. 2017: Using relevébased metrics to explain invasion patterns of alien trees in temperate forests. Tuexenia 37(1): 127-142. https://doi.org/10.14471/2017.37.012

6. *Cabra-Rivas, I., Saldaña, A., Castro-Díez, P. \& Gallien, L. 2016: A multi-scale approach to identify invasion drivers and invaders' future dynamics. Biological Invasions 18(2): 411-426. https://doi.org/10.1007/ s10530-015-1015-z

7. *Čarni, A., Mastnak, N.J., Dakskobler, I., Kutnar, L., Marinšek, A. \& Šilc, U. 2017: Prediction of the appearance of tree of heaven in forestcommunities in western Slovenia. Periodicum Biologorum 119(4): 261-283. https://doi.org/10.18054/pb.v119i4.4483

8. *Celesti-Grapow, L. \& Blasi, C. 2004: The role of alien and native weeds in the deterioration of archaeological remains in Italy. Weed Technology 18 (Suppl.1): 1508-1513. https://doi.org/10.1614/0890037X(2004)018[1508:TROAAN]2.0.CO;2

9. *Constán-Nava, S. \& Bonet, A. 2012: Genetic variability modulates the effect of habitat type and environmental conditions on early invasion success of Ailanthus altissima in Mediterranean ecosystems. Biological Invasions 14(11): 2379-2392. https://doi. org/10.1007/s10530-012-0236-7

10. *Constán-Nava, S., Bonet, A., Pastor, E. \& Lledó, M.J. 2010: Long-term control of the invasive tree Ailanthus altissima: Insights from Mediterranean protected for- ests. Forest Ecology and Management 260(6): 10581064. https://doi.org/10.1016/j.foreco.2010.06.030

11. *Constán-Nava, S., Soliveres, S., Torices, R., Serra, L. $\&$ Bonet, A. 2015: Direct and indirect effects of invasion by the alien tree Ailanthus altissima on riparian plant communities and ecosystem multifunctionality. Biological Invasions 17(4): 1095-1108. https:// doi.org/10.1007/s10530-014-0780-4

12. ${ }^{*}$ Crandall, R.M. \& Knight, T.M. 2018: Role of multiple invasion mechanisms and their interaction in regulating the population dynamics of an exotic tree. Journal of Applied Ecology 55(2): 885-894. https:// doi.org/10.1111/1365-2664.13020

13. *Espenschied-Reilly, A.L. \& Runkle, J.R. 2008: Distribution and changes in abundance of Ailanthus altissima (Miller) swingle in a southwest Ohio woodlot. Ohio Journal of Science 108(2): 16-22.

14. *Essl, F., Milasowszky, N. \& Dirnböck, T. 2011: Plant invasions in temperate forests: Resistance or ephemeral phenomenon? Basic and Applied Ecology 12(1): 1-9. https://doi.org/10.1016/j.baae.2010.10.003

15. *Facelli, J.M. 1994: Multiple indirect effects of plant litter affect the establishment of woody seedlings in old fields. Ecology 75(6): 1727-1735. https://doi. org/10.2307/1939632

16. *Fotiadis, G., Kyriazopoulos, A.P. \& Fraggakis, I. 2011: The behaviour of Ailanthus altissima weed and its effects on natural ecosystems. Journal of Environmental Biology 32(6): 801-806.

17. *Gómez-Aparicio, L. \& Canham, C.D. 2008: Neighborhood models of the effects of invasive tree species on ecosystem processes. Ecological Monographs 78(1): 69-86. https://doi.org/10.1890/06-2036.1

18. *Guthrie, S.G., Crandall, R.M. \& Knight, T.M. 2016: Fire indirectly benefits fitness in two invasive species. Biological Invasions 18(5): 1265-1273. https://doi.org/10.1007/s10530-016-1064-y

19. *Hadjikyriakou, G. \& Hadjisterkotis, E. 2002: The adventive plants of Cyprus with new records of invasive species. Zeitschrift für Jagdwissenschaft 48(Suppl.1): 59-71. https://doi.org/10.1007/BF02192393

20. *Harris, P.T., Cannon, G.H., Smith, N.E. \& Muth, N.Z. 2013: Assessment of plant community restoration following Tree-of-Heaven (Ailanthus altissima) control by Verticillium albo-atrum. Biological Invasions 15(9): 1887-1893. https://doi.org/10.1007/ s10530-013-0430-2

21. *Hill, S.R. 1996: The flora of Latimer Point and vicinity, New London County, Connecticut. Rhodora 98(894): 180-216.

22. *Höfle, R., Dullinger, S. \& Essl, F. 2014: Different factors affect the local distribution, persistence and 
spread of alien tree species in floodplain forests. Basic and Applied Ecology 15(5): 426-434. https://doi. org/10.1016/j.baae.2014.07.007

23. *Horvat, G. \& Franjić, J. 2016: Invasive plants of Kalnik forests. Sumarski List 140(1-2): 53-64.

24. *Huebner, C.D., Regula, A.E. \& McGill, D.W. 2018: Germination, survival, and early growth of three invasive plants in response to five forest management regimes common to US northeastern deciduous forests. Forest Ecology and Management 425: 100118. https://doi.org/10.1016/j.foreco.2018.05.037

25. *Kaproth, M.A. \& McGraw, J.B. 2008: Seed viability and dispersal of the wind-dispersed invasive Ailanthus altissima in aqueous environments. Forest Science 54(5): 490-496.

26. Kasson, M.T., Davis, M.D. \& Davis, D.D. 2013: The Invasive Ailanthus altissima in Pennsylvania: A Case Study Elucidating Species Introduction, Migration, Invasion, and Growth Patterns in the Northeastern US. Northeastern Naturalist 20: 1-60.

27. *Knapp, L.B. \& Canham, C.D. 2000: Invasion of an old-growth forest in New York by Ailanthus altissima: Sapling growth and recruitment in canopy gaps. Journal of the Torrey Botanical Society 127(4): 307-315. https://doi.org/10.2307/3088649

28. *Knüsel, S., Conedera, M., Rigling, A., Fonti, P. \& Wunder, J. 2015: A tree-ring perspective on the invasion of Ailanthus altissima in protection forests. Forest Ecology and Management 354: 334-343. https:// doi.org/10.1016/j.foreco.2015.05.010

29. *Knüsel, S., De Boni, A., Conedera, M., Schleppi, P., Thormann, J.J., Frehner, M. \& Wunder, J. 2017: Shade tolerance of Ailanthus altissima revisited: novel insights from southern Switzerland. Biological Invasions 19(2): 455-461. https://doi.org/10.1007/ s10530-016-1301-4

30. *Knüsel, S., Conedera, M., Zweifel, R., Bugmann, H., Etzold, S. \& Wunder, J. 2019: High growth potential of Ailanthus altissima in warm and dry weather conditions in novel forests of southern Switzerland. Trees - Structure and Function 33(2): 395-409. https://doi.org/10.1007/s00468-018-1785-x

31. *Kota, N.L., Landenberger, R.E. \& McGraw, J.B. 2007: Germination and early growth of Ailanthus and tulip poplar in three levels of forest disturbance. Biological Invasions 9(2): 197-211. https://doi. org/10.1007/s10530-006-9026-4

32. ${ }^{*}$ Kowarik, I. 1995: Clonal growth in Ailanthus altissima on a natural site in West Virginia. Journal of Vegetation Science 6(6): 853-856. https://doi. org $/ 10.2307 / 3236399$

33. * Landenberger, R.E., Kota, N.L. \& McGraw, J.B.
2007: Seed dispersal of the non-native invasive tree Ailanthus altissima into contrasting environments. Plant Ecology 192(1): 55-70. https://doi. org/10.1007/s11258-006-9226-0

34. *Lookingbill, T.R., Minor, E.S., Bukach, N., Ferrari, J.R. \& Wainger, L.A. 2014: Incorporating risk of reinvasion to prioritize sites for invasive species management. Natural Areas Journal 34(3): 268-281. https://doi.org/10.3375/043.034.0303

35. Marris, E. 2005: Invasive species: Shoot to kill. Nature 438(7066): 272-273. https://doi. org/10.1038/438272a

36. ${ }^{*}$ Martin, P.H. \& Canham, C.D. 2010: Dispersal and recruitment limitation in native versus exotic tree species: Life-history strategies and Janzen-Connell effects. Oikos 119(5): 807-824. https://doi. org/10.1111/j.1600-0706.2009.17941.x

37. ${ }^{*}$ Martin, P.H., Canham, C.D. \& Kobe, R.K. 2010: Divergence from the growth-survival trade-off and extreme high growth rates drive patterns of exotic tree invasions in closed-canopy forests. Journal of Ecology 98(4): 778-789. https://doi.org/10.1111/ j.1365-2745.2010.01666.x

38. *Marwat, K.B., Hashim, S. \& Ali, H. 2010: Weed management: A case study from north-west Pakistan. Pakistan Journal of Botany 42(Special Issue): 341-353.

39. *Mayoral, O., Mascia, F., Podda, L., Laguna, E., Fraga, P., Rita, J., Frigau, L. \& Bacchetta, G. 2018: Alien Plant Diversity in Mediterranean Wetlands: A Comparative Study within Valencian, Balearic and Sardinian Floras. Notulae Botanicae Horti Agrobotanici Cluj-Napoca 46(2): 317-326. https://doi. org/10.15835/nbha46210470

40. ${ }^{*}$ McAvoy, T.J., Snyder, A.L., Johnson, N., Salom, S.M. \& Kok, L.T. 2012: Road survey of the invasive tree-of-heaven (Ailanthus altissima) in Virginia. Invasive Plant Science and Management 5(4): 506-512. https://doi.org/10.1614/IPSM-D-12-00039.1

41. *Meloche, C. \& Murphy, S.D. 2006: Managing tree-of-heaven (Ailanthus altissima) in parks and protected areas: A case study of Rondeau Provincial Park (Ontario, Canada). Environmental Management 37(6): 764-772. https://doi.org/10.1007/s00267003-0151-x

42. *Motard, E., Dusz, S., Geslin, B., Akpa-Vinceslas, M., Hignard, C., Babiar, O., Clair-Maczulajtys, D. \& Michel-Salzat, A. 2015: How invasion by Ailanthus altissima transforms soil and litter communities in a temperate forest ecosystem. Biological Invasions 17(6): 1817-1832. https://doi.org/10.1007/s10530014-0838-3 
43. *Nemec, K.T., Allen, C.R., Alai, A., Clements, G., Kessler, A.C., Kinsell, T., Major, A. \& Stephen, B.J. 2011: Woody invasions of urban trails and the changing face of urban forests in the great plains, USA. American Midland Naturalist 165(2): 241256. https://doi.org/10.1674/0003-0031-165.2.241

44. *Nilsen, E.T., Huebner, C.D., Carr, D.E. \& Bao, Z. 2018: Interaction between Ailanthus altissima and native Robinia pseudoacacia in early succession: Implications for forest management. Forests 9(4): 221. https://doi.org/10.3390/f9040221

45. Novak, N. \& Novak, M. 2018: The differences in the invasiveness of some alien plant species between continental and coastal part of Croatia. Poljoprivreda 24(2): 63-69. https://doi.org/10.18047/poljo.24.2.9

46. O’Neal, E.S. \& Davis, D.D. 2014: Biological control of invasive Ailanthus altissima using formulated and natural Verticillium nonalfalfae inoculum. Phytopathology 104(11): 162-163.

47. *Pennington, D.N., Hansel, J.R. \& Gorchov, D.L. 2010: Urbanization and riparian forest woody communities: Diversity, composition, and structure within a metropolitan landscape. Biological Conservation 143(1): 182-194. https://doi.org/10.1016/j. biocon.2009.10.002

48. *Planchuelo, G., Catalán, P. \& Delgado, J.A. 2016: Gone with the wind and the stream: Dispersal in the invasive species Ailanthus altissima. Acta Oecologica 73: 31-37. https://doi.org/10.1016/j.actao.2016.02.006

49. *Radtke, A., Ambraß, S., Zerbe, S., Tonon, G., Fontana, V. \& Ammer, C. 2013: Traditional coppice forest management drives the invasion of Ailanthus altissima and Robinia pseudoacacia into deciduous forests. Forest Ecology and Management 291: 308317. https://doi.org/10.1016/j.foreco.2012.11.022

50. *Rebbeck, J., Hutchinson, T., Iverson, L., Yaussy, D. \& Fox, T. 2017: Distribution and demographics of Ailanthus altissima in an oak forest landscape managed with timber harvesting and prescribed fire. Forest Ecology and Management 401: 233-241. https:// doi.org/10.1016/j.foreco.2017.06.050

51. *Rebbeck, J., Hutchinson, T.F. \& Iverson, L.R. 2019: Effects of prescribed fire and stem-injection herbicide on Ailanthus altissima demographics and survival. Forest Ecology and Management 439: 122-131. https://doi.org/10.1016/j.foreco.2019.02.044

52. *Siderhurst, L.A., Griscom, H.P., Kyger, C., Stutzman, J. \& Trumbo, B. 2012: Tree species composition and diversity and the abundance of exotics in forest fragments of the Shenandoah Valley, Virginia. Castanea 77(4): 348-363. https://doi.org/10.2179/11-021
53. *Sladonja, B. \& Poljuha, D. 2018: Citizen science as a tool in biological recording-A case study of $\mathrm{Ai}$ lanthus altissima (Mill.) Swingle. Forests 9(1): 31. https://doi.org/10.3390/f9010031

54. *Spáčilová, B. \& Stredová, H. 2014: Disputed recreational and ecological stabilization functions of celected windbreaks. In: D. Pernicova, J. Fialova (eds.): Public Recreation and Landscape Protection - With Man Hand in Hand? Mendel University in Brno, Brno, pp. 85-91.

55. *Tafra, D., Pandža, M. \& Milović, M. 2012: Woody plants of the Omis. Sumarski List 136(11-12): 605-617.

56. *Tarantino, C., Casella, F., Adamo, M., Lucas, R., Beierkuhnlein, C. \& Blonda, P. 2019: Ailanthus altissima mapping from multi-temporal very high resolution satellite images. ISPRS Journal of Photogrammetry and Remote Sensing 147: 90-103. https://doi.org/10.1016/j.isprsjprs.2018.11.013

57. *Trájer, A., Hammer, T., Bede-Fazekas, Á., Schoffhauzer, J. \& Padisák, J. 2016: The comparison of the potential effect of climate change on the segment growth of Fraxinus ornus, Pinus nigra and Ailanthus altissima on shallow, calcareous soils. Applied Ecology and Environmental Research 14(3): 161-182. https://doi.org/10.15666/aeer/1403_161182

58. *Traveset, A., Brundu, G., Carta, L., Mprezetou, I., Lambdon, P., Manca, M., Médail, F., Moragues, E., Rodríguez-Pérez, J., Siamantziouras, A.S.D., Suehs, C.M., Troumbis, A.Y., Vilà, M. \& Hulme, P.E. 2008: Consistent performance of invasive plant species within and among islands of the Mediterranean basin. Biological Invasions 10(6): 847-858. https:// doi.org/10.1007/s10530-008-9245-y

59. *Tsiotsiou, V. \& Christodoulakis, D. 2010: Woody plants in urban biotopes: Studies in Patras (Greece). Fresenius Environmental Bulletin 19(12A): 29582965.

60. *Vilà, M., Siamantziouras, A.S.D., Brundu, G., Camarda, I., Lambdon, P., Médail, F., Moragues, E., Suehs, C.M., Traveset, A., Troumbis, A.Y. \& Hulme, P.E. 2008: Widespread resistance of Mediterranean island ecosystems to the establishment of three alien species. Diversity and Distributions 14(5): 839-851. https://doi.org/10.1111/j.14724642.2008.00503.x

61. *Vilà, M., Tessier, M., Suehs, C.M., Brundu, G., Carta, L., Galanidis, A., Lambdon, P., Manca, M., Médail, F., Moragues, E., Traveset, A., Troumbis, A.Y. \& Hulme, P.E. 2006: Local and regional assessments of the impacts of plant invaders on vegetation structure and soil properties of Mediterranean 
islands. Journal of Biogeography 33(5): 853-861. https://doi.org/10.1111/j.1365-2699.2005.01430.x

62. *Vukojević, M. \& Vitasović Kosić, I. 2012: Mountain matokit and vrgorac city: A new localities of threatened and invasive plant taxa in Croatia. Journal of Central European Agriculture 13(1): 150-166. https://doi.org/10.5513/JCEA01/13.1.1027

63. *Zelnik, I., Haler, M. \& Gaberscik, A. 2015: Vulnerability of a riparian zone towards invasion by alien plants depends on its structure. Biologia 70(7): 869878. https://doi.org/10.1515/biolog-2015-0110

\section{Bibliography of included papers from Scopus}

1. *Affre, L., Suehs, C.M., Charpentier, S., Vilà, M., Brundu, G., Lambdon, P., Traveset, A. \& Hulme, P.E. 2010: Consistency in the habitat degree of invasion for three invasive plant species across Mediterranean islands. Biological Invasions 12(8): 2537-2548. https://doi.org/10.1007/s10530-009-9662-6

2. *Akatov, V.V., Akatova, T.V. \& Shadzhe, A.E. 2012: Species richness of tree and shrub layers in riparian forests of the Western Caucasus dominated by alien species. Russian Journal of Ecology 43(4): 294-301. https://doi.org/10.1134/S1067413612040030

3. Ambrass, V.S., Radtke, A., Zerbe, S., Fontana, V. \& Ammer, C. 2014: Propagation and management of ailanthus and black locust in coppice forests: Insights from a case study on invasive species in South Tyrol. Naturschutz und Landschaftsplanung 46(2): 45-51.

4. *Anderson, M. \& Crosby, M.K. 2018: An assessment of invasive plants on Shorter University's Campus. Mathematical and Computational Forestry \& Natural Resource Sciences 10(1): 24-29.

5. *Berg, C., Drescher, A., Wagner, V. \& Essl, F. 2016: Temporal trends in the invasions of Austrian woodlands by alien trees. Preslia 88(2): 185-200.

6. *Berg, C., Drescher, A. \& Essl, F. 2017: Using relevébased metrics to explain invasion patterns of alien trees in temperate forests. Tuexenia 37(1): 127-142. https://doi.org/10.14471/2017.37.012

7. Burch, P.L. \& Zedaker, S.M. 2003: Removing the invasive tree Ailanthus altissima and restoring natural cover. Journal of Arboriculture 29(1): 18-24.

8. *Cabra-Rivas, I., Saldaña, A., Castro-Díez, P. \& Gallien, L. 2016: A multi-scale approach to identify invasion drivers and invaders' future dynamics. Biological Invasions 18(2): 411-426. https://doi.org/10.1007/ s10530-015-1015-z

9. *Čarni, A., Mastnak, N.J., Dakskobler, I., Kutnar, L., Marinšek, A. \& Šilc, U. 2017: Prediction of the appearance of tree of heaven in forestcommunities in western Slovenia. Periodicum Biologorum 119(4): 261-283. https://doi.org/10.18054/pb.v119i4.4483

10. ${ }^{*}$ Celesti-Grapow, L. \& Blasi, C. 2004: The role of alien and native weeds in the deterioration of archaeological remains in Italy. Weed Technology 18 (Suppl.1): 1508-1513. https://doi.org/10.1614/0890037X(2004)018[1508:TROAAN]2.0.CO;2

11. *Constán-Nava, S. \& Bonet, A. 2012: Genetic variability modulates the effect of habitat type and environmental conditions on early invasion success of Ailanthus altissima in Mediterranean ecosystems. Biological Invasions 14(11): 2379-2392. https://doi. org/10.1007/s10530-012-0236-7

12. *Constán-Nava, S., Bonet, A., Pastor, E. \& Lledó, M.J. 2010: Long-term control of the invasive tree Ailanthus altissima: Insights from Mediterranean protected forests. Forest Ecology and Management 260(6): 1058 1064. https://doi.org/10.1016/j.foreco.2010.06.030

13. *Constán-Nava, S., Soliveres, S., Torices, R., Serra, L. $\&$ Bonet, A. 2015: Direct and indirect effects of invasion by the alien tree Ailanthus altissima on riparian plant communities and ecosystem multifunctionality. Biological Invasions 17(4): 1095-1108. https:// doi.org/10.1007/s10530-014-0780-4

14. ${ }^{*}$ Crandall, R.M. \& Knight, T.M. 2018: Role of multiple invasion mechanisms and their interaction in regulating the population dynamics of an exotic tree. Journal of Applied Ecology 55(2): 885-894. https:// doi.org/10.1111/1365-2664.13020

15. Ebone, A., Cristaldi, L., Buzio, S. \& Chiarabaglio, P.M. 2015: Invasive alien species management in forest and protected areas. Italian Botanist 47(2): 370-371.

16. *Espenschied-Reilly, A.L. \& Runkle, J.R. 2008: Distribution and changes in abundance of Ailanthus altissima (Miller) swingle in a southwest Ohio woodlot. Ohio Journal of Science 108(2): 16-22.

17. *Essl, F., Milasowszky, N. \& Dirnböck, T. 2011 : Plant invasions in temperate forests: Resistance or ephemeral phenomenon? Basic and Applied Ecology 12(1): 1-9. https://doi.org/10.1016/j.baae.2010.10.003

18. *Facelli, J.M. 1994: Multiple indirect effects of plant litter affect the establishment of woody seedlings in old fields. Ecology 75(6): 1727-1735. https://doi. org/10.2307/1939632

19. Ferrero, A. \& Vidotto, F. 2015: Control of three-ofheaven (Ailanthus altissima) in the fortress "Cittadella" of Alessandria. Italian Botanist 47(2): 381-382.

20. ${ }^{*}$ Fotiadis, G., Kyriazopoulos, A.P. \& Fraggakis, I. 2011: The behaviour of Ailanthus altissima weed and its effects on natural ecosystems. Journal of Environmental Biology 32(6): 801-806. 
21. Glišić, M., Lakušić, O., Šinžar-Sekulić, J. \& Jovanović, S. 2014: GIS analysis of spatial distribution of invasive tree species in the protected natural area of $\mathrm{Mt}$. Avala (Serbia). Botanica Serbica 38(1): 131-138.

22. *Gómez-Aparicio, L. \& Canham, C.D. 2008: Neighborhood models of the effects of invasive tree species on ecosystem processes. Ecological Monographs 78(1): 69-86. https://doi.org/10.1890/06-2036.1

23. Grigorescu, I., Dumitraşcu, M., Kucsicsa, G., Doroftei, M., Năstase, M. \& Dragota, C.-S. 2016: Predicting the potential distribution of Ailanthus altissima, an invasive terrestrial plant species in macin mountains national park (Romania). In: Koulov B., Zhelezov G. (eds.): Sustainable Mountain Regions: Challenges and Perspectives in Southeastern Europe. Springer International Publishing, pp. 159-172. https://doi.org/10.1007/978-3-319-27905-3_12

24. Grigorov, B. 2016: Invasive plant species in the northern part of Mala Planina. In: Koulov B., Zhelezov G. (eds.): Sustainable Mountain Regions: Challenges and Perspectives in Southeastern Europe. Springer International Publishing, pp. 219-229. https://doi. org/10.1007/978-3-319-27905-3_16

25. ${ }^{*}$ Guthrie, S.G., Crandall, R.M. \& Knight, T.M. 2016: Fire indirectly benefits fitness in two invasive species. Biological Invasions 18(5): 1265-1273. https://doi.org/10.1007/s10530-016-1064-y

26. *Hadjikyriakou, G. \& Hadjisterkotis, E. 2002: The adventive plants of Cyprus with new records of invasive species. Zeitschrift für Jagdwissenschaft 48(Suppl.1): 59-71. https://doi.org/10.1007/BF02192393

27. Hahn, I., Gergely, A. \& Barabás, S. 2011: Changes in the active floodplain vegetation of the Szigetköz. Annals of Botany 1: 1-8.

28. *Harris, P.T., Cannon, G.H., Smith, N.E. \& Muth, N.Z. 2013: Assessment of plant community restoration following Tree-of-Heaven (Ailanthus altissima) control by Verticillium albo-atrum. Biological Invasions 15(9): 1887-1893. https://doi.org/10.1007/ s10530-013-0430-2

29. *Hill, S.R. 1996: The flora of Latimer Point and vicinity, New London County, Connecticut. Rhodora 98(894): 180-216.

30. ${ }^{*}$ Höfle, R., Dullinger, S. \& Essl, F. 2014: Different factors affect the local distribution, persistence and spread of alien tree species in floodplain forests. Basic and Applied Ecology 15(5): 426-434. https://doi. org/10.1016/j.baae.2014.07.007

31. *Horvat, G. \& Franjić, J. 2016: Invasive plants of Kalnik forests. Sumarski List 140(1-2): 53-64.

32. *Huebner, C.D., Regula, A.E. \& McGill, D.W. 2018: Germination, survival, and early growth of three in- vasive plants in response to five forest management regimes common to US northeastern deciduous forests. Forest Ecology and Management 425: 100-118. https://doi.org/10.1016/j.foreco.2018.05.037

33. Hulina, N. 2010: "Planta hortifuga" in flora of the continental part of Croatia. Agriculturae Conspectus Scientificus 75(2): 57-65.

34. Idžojtić, M. \& Zebec, M. 2006: Distribution of the tree of heaven (Ailanthus altissima (Mill.) Swingle) and spreading of invasive woody alien species in Croatia. Glasnik za Sumske Pokuse 5(Special Issue): 315-323.

35. *Kaproth, M.A. \& McGraw, J.B. 2008: Seed viability and dispersal of the wind-dispersed invasive Ailanthus altissima in aqueous environments. Forest Science 54(5): 490-496.

36. Kelbel, P. 2012: Comparison of invasive woody plant species presence in the Botanical garden of P.J. Šafárik University in Košice from the viewpoint of time and management of sanitation measures. Thaiszia Journal of Botany 22(2): 163-180.

37. *Knapp, L.B. \& Canham, C.D. 2000: Invasion of an old-growth forest in New York by Ailanthus altissima: Sapling growth and recruitment in canopy gaps. Journal of the Torrey Botanical Society 127(4): 307-315. https://doi.org/10.2307/3088649

38. *Knüsel, S., Conedera, M., Rigling, A., Fonti, P. \& Wunder, J. 2015: A tree-ring perspective on the invasion of Ailanthus altissima in protection forests. Forest Ecology and Management 354: 334-343. https:// doi.org/10.1016/j.foreco.2015.05.010

39. *Knüsel, S., De Boni, A., Conedera, M., Schleppi, P., Thormann, J.J., Frehner, M. \& Wunder, J. 2017: Shade tolerance of Ailanthus altissima revisited: novel insights from southern Switzerland. Biological Invasions 19(2): 455-461. https://doi.org/10.1007/ s10530-016-1301-4

40. *Knüsel, S., Conedera, M., Zweifel, R., Bugmann, H., Etzold, S. \& Wunder, J. 2019: High growth potential of Ailanthus altissima in warm and dry weather conditions in novel forests of southern Switzerland. Trees - Structure and Function 33(2): 395-409. https://doi.org/10.1007/s00468-018-1785-x

41. *Kota, N.L., Landenberger, R.E. \& McGraw, J.B. 2007: Germination and early growth of Ailanthus and tulip poplar in three levels of forest disturbance. Biological Invasions 9(2): 197-211. https://doi. org/10.1007/s10530-006-9026-4

42. *Kowarik, I. 1995: Clonal growth in Ailanthus altissima on a natural site in West Virginia. Journal of Vegetation Science 6(6): 853-856. https://doi. org/10.2307/3236399 
43. *Landenberger, R.E., Kota, N.L. \& McGraw, J.B. 2007: Seed dispersal of the non-native invasive tree Ailanthus altissima into contrasting environments. Plant Ecology 192(1): 55-70. https://doi. org/10.1007/s11258-006-9226-0

44. *Lookingbill, T.R., Minor, E.S., Bukach, N., Ferrari, J.R. \& Wainger, L.A. 2014: Incorporating risk of reinvasion to prioritize sites for invasive species management. Natural Areas Journal 34(3): 268-281. https://doi.org/10.3375/043.034.0303

45. Luigi Nimis, P., Pittao, E., Altobelli, A., De Pascalis, F., Laganis, J. \& Martellos, S. 2018: Mapping invasive plants with citizen science. A case study from Trieste (NE Italy). Plant Biosystems. https://doi.org/10. 1080/11263504.2018.1536085

46. ${ }^{*}$ Martin, P.H. \& Canham, C.D. 2010: Dispersal and recruitment limitation in native versus exotic tree species: Life-history strategies and Janzen-Connell effects. Oikos 119(5): 807-824. https://doi. org/10.1111/j.1600-0706.2009.17941.x

47. *Martin, P.H., Canham, C.D. \& Kobe, R.K. 2010: Divergence from the growth-survival trade-off and extreme high growth rates drive patterns of exotic tree invasions in closed-canopy forests. Journal of Ecology 98(4): 778-789. https://doi.org/10.1111/ j.1365-2745.2010.01666.x

48. *Marwat, K.B., Hashim, S. \& Ali, H. 2010: Weed management: A case study from north-west Pakistan. Pakistan Journal of Botany 42(Special Issue): 341-353.

49. *Mayoral, O., Mascia, F., Podda, L., Laguna, E., Fraga, P., Rita, J., Frigau, L. \& Bacchetta, G. 2018: Alien Plant Diversity in Mediterranean Wetlands: A Comparative Study within Valencian, Balearic and Sardinian Floras. Notulae Botanicae Horti Agrobotanici Cluj-Napoca 46(2): 317-326. https://doi. org/10.15835/nbha46210470

50. *McAvoy, T.J., Snyder, A.L., Johnson, N., Salom, S.M. \& Kok, L.T. 2012: Road survey of the invasive tree-of-heaven (Ailanthus altissima) in Virginia. Invasive Plant Science and Management 5(4): 506-512. https://doi.org/10.1614/IPSM-D-12-00039.1

51. ${ }^{*}$ Meloche, C. \& Murphy, S.D. 2006: Managing tree-of-heaven (Ailanthus altissima) in parks and protected areas: A case study of Rondeau Provincial Park (Ontario, Canada). Environmental Management 37(6): 764-772. https://doi.org/10.1007/ s00267-003-0151-x

52. Möllerová, J. 2005: Notes on invasive and expansive trees and shrubs. Journal of Forest Science 51: 19-23.

53. *Motard, E., Dusz, S., Geslin, B., Akpa-Vinceslas, M., Hignard, C., Babiar, O., Clair-Maczulajtys, D.
\& Michel-Salzat, A. 2015: How invasion by Ailanthus altissima transforms soil and litter communities in a temperate forest ecosystem. Biological Invasions 17(6): 1817-1832. https://doi.org/10.1007/s10530014-0838-3

54. ${ }^{*}$ Nemec, K.T., Allen, C.R., Alai, A., Clements, G., Kessler, A.C., Kinsell, T., Major, A. \& Stephen, B.J. 2011: Woody invasions of urban trails and the changing face of urban forests in the great plains, USA. American Midland Naturalist 165(2): 241256. https://doi.org/10.1674/0003-0031-165.2.241

55. *Nilsen, E.T., Huebner, C.D., Carr, D.E. \& Bao, Z. 2018: Interaction between Ailanthus altissima and native Robinia pseudoacacia in early succession: Implications for forest management. Forests 9(4): 221. https://doi.org/10.3390/f9040221

56. Pauková, Z. 2013: Invasive plant species in the three microregions of Nitra region, south-west Slovakia. Ekológia (Bratislava) 32(2): 262-266. https://doi. org/10.2478/eko-2013-0022

57. *Pennington, D.N., Hansel, J.R. \& Gorchov, D.L. 2010: Urbanization and riparian forest woody communities: Diversity, composition, and structure within a metropolitan landscape. Biological Conservation 143(1): 182-194. https://doi.org/10.1016/j. biocon.2009.10.002

58. *Planchuelo, G., Catalán, P. \& Delgado, J.A. 2016: Gone with the wind and the stream: Dispersal in the invasive species Ailanthus altissima. Acta Oecologica 73: 31-37. https://doi.org/10.1016/j.actao.2016.02.006

59. *Radtke, A., Ambraß, S., Zerbe, S., Tonon, G., Fontana, V. \& Ammer, C. 2013: Traditional coppice forest management drives the invasion of Ailanthus altissima and Robinia pseudoacacia into deciduous forests. Forest Ecology and Management 291: 308317. https://doi.org/10.1016/j.foreco.2012.11.022

60. *Rebbeck, J., Hutchinson, T., Iverson, L., Yaussy, D. \& Fox, T. 2017: Distribution and demographics of Ailanthus altissima in an oak forest landscape managed with timber harvesting and prescribed fire. Forest Ecology and Management 401: 233-241. https:// doi.org/10.1016/j.foreco.2017.06.050

61. *Rebbeck, J., Hutchinson, T.F. \& Iverson, L.R. 2019: Effects of prescribed fire and stem-injection herbicide on Ailanthus altissima demographics and survival. Forest Ecology and Management 439: 122-131. https://doi.org/10.1016/j.foreco.2019.02.044

62. Schuster, W.S.F., Griffin, K.L., Roth, H., Turnbull, M.H., Whitehead, D. \& Tissue, D.T. 2008: Changes in composition, structure and aboveground biomass over seventy-six years (1930-2006) in the Black Rock 
Forest, Hudson Highlands, southeastern New York State. Tree Physiology 28(4): 537-549. https://doi. org/10.1093/treephys/28.4.537

63. *Siderhurst, L.A., Griscom, H.P., Kyger, C., Stutzman, J. \& Trumbo, B. 2012: Tree species composition and diversity and the abundance of exotics in forest fragments of the Shenandoah Valley, Virginia. Castanea 77(4): 348-363. https://doi.org/10.2179/11-021

64. *Sladonja, B. \& Poljuha, D. 2018: Citizen science as a tool in biological recording-A case study of $\mathrm{Ai}$ lanthus altissima (Mill.) Swingle. Forests 9(1): 31. https://doi.org/10.3390/f9010031

65. *Spáćilová, B. \& Stredová, H. 2014: Disputed recreational and ecological stabilization functions of celected windbreaks. In: D. Pernicova, J. Fialova (eds.): Public Recreation and Landscape Protection - With Man Hand in Hand? Mendel University in Brno, Brno, pp. 85-91.

66. Stalter, R., Kincaid, D. \& Byer, M. 2009: Control of normative invasive woody plant species at Jamaica Bay Wildlife Refuge, New York City. Arboriculture \& Urban Forestry 35(3): 152-156.

67. Stešević, D., Caković, D. \& Jovanović, S. 2014: The Urban Flora of Podgorica (Montenegro, SE Europe): Annotated Checklist, Distribution Atlas, Habitats and Life-Forms, Taxonomic, Phytogeographical and Ecological Analysis. Ecologica Montenegrina 1(4): $1-171$.

68. Stinca, A. \& Motti, R. 2017: Alien plant invasions in Astroni crater, a decades-long unmanaged forest in southern Italy. Atti della Societa Toscana di Scienze Naturali, Memorie Serie B 124: 101-108. https:// doi.org/10.2424/ASTSN.M.2017.10

69. *Tafra, D., Pandža, M. \& Milović, M. 2012: Woody plants of the Omis. Sumarski List 136(11-12): 605-617.

70. *Tarantino, C., Casella, F., Adamo, M., Lucas, R., Beierkuhnlein, C. \& Blonda, P. 2019: Ailanthus altissima mapping from multi-temporal very high resolution satellite images. ISPRS Journal of Photogrammetry and Remote Sensing 147: 90-103. https://doi.org/10.1016/j.isprsjprs.2018.11.013

71. Tóth, A., Balogh, Á., Wichmann, B., Penksza, A., Gyulai, F., Berke, J., Uj, B., Házi, J. \& Penksza, K. 2012: Weed vegetation changes in Gödöllo-hill area respectively to marginal and agricultural areas. Landscape and Urban Planning 10(2): 447-456.

72. *Trájer, A., Hammer, T., Bede-Fazekas, Á., Schoffhauzer, J. \& Padisák, J. 2016: The comparison of the potential effect of climate change on the segment growth of Fraxinus ornus, Pinus nigra and Ailanthus altissima on shallow, calcareous soils. Applied Ecol- ogy and Environmental Research 14(3): 161-182. https://doi.org/10.15666/aeer/1403_161182

73. *Traveset, A., Brundu, G., Carta, L., Mprezetou, I., Lambdon, P., Manca, M., Médail, F., Moragues, E., Rodríguez-Pérez, J., Siamantziouras, A.S.D., Suehs, C.M., Troumbis, A.Y., Vilà, M. \& Hulme, P.E. 2008: Consistent performance of invasive plant species within and among islands of the Mediterranean basin. Biological Invasions 10(6): 847-858. https:// doi.org/10.1007/s10530-008-9245-y

74. *Tsiotsiou, V. \& Christodoulakis, D. 2010: Woody plants in urban biotopes: Studies in Patras (Greece). Fresenius Environmental Bulletin 19(12A): 29582965.

75. Uboni, C., Tordoni, E., Brandmayr, P., Battistella, S., Bragato, G., Castello, M., Colombetta, G., Poldini, L. \& Bacaro, G. 2019: Exploring cross-taxon congruence between carabid beetles (Coleoptera: Carabidae) and vascular plants in sites invaded by $A i-$ lanthus altissima versus non-invaded sites: The explicative power of biotic and abiotic factors. Ecological Indicators 103: 145-155. https://doi.org/10.1016/j. ecolind.2019.03.052

76. *Vilà, M., Siamantziouras, A.S.D., Brundu, G., Camarda, I., Lambdon, P., Médail, F., Moragues, E., Suehs, C.M., Traveset, A., Troumbis, A.Y. \& Hulme, P.E. 2008: Widespread resistance of Mediterranean island ecosystems to the establishment of three alien species. Diversity and Distributions 14(5): 839-851. https://doi.org/10.1111/j.1472-4642.2008.00503.x

77. *Vilà, M., Tessier, M., Suehs, C.M., Brundu, G., Carta, L., Galanidis, A., Lambdon, P., Manca, M., Médail, F., Moragues, E., Traveset, A., Troumbis, A.Y. \& Hulme, P.E. 2006: Local and regional assessments of the impacts of plant invaders on vegetation structure and soil properties of Mediterranean islands. Journal of Biogeography 33(5): 853-861. https://doi.org/10.1111/j.1365-2699.2005.01430.x

78. *Vukojević, M. \& Vitasović Kosić, I. 2012: Mountain matokit and vrgorac city: A new localities of threatened and invasive plant taxa in Croatia. Journal of Central European Agriculture 13(1): 150-166. https://doi.org/10.5513/JCEA01/13.1.1027

79. *Zelnik, I., Haler, M. \& Gaberscik, A. 2015: Vulnerability of a riparian zone towards invasion by alien plants depends on its structure. Biologia 70(7): 869878. https://doi.org/10.1515/biolog-2015-0110 